\section{Pacific Northwest}

National Laboratory

Operated by Battelle for the

U.S. Department of Energy

\title{
Urban Dispersion Program Overview and MID05 Field Study Summary
}

K. J. Allwine

J. E. Flaherty

July 2007

Prepared for the U.S. Department of Homeland Security under a Related Services Agreement with the U.S. Department of Energy under contract DE-AC05-76RL01830 


\title{
DISCLAIMER
}

This report was prepared as an account of work sponsored by an agency of the United States Government. Neither the United States Government nor any agency thereof, nor Battelle Memorial Institute, nor any of their employees, makes any warranty, express or implied, or assumes any legal liability or responsibility for the accuracy, completeness, or usefulness of any information, apparatus, product, or process disclosed, or represents that its use would not infringe privately owned rights. Reference herein to any specific commercial product, process, or service by trade name, trademark, manufacturer, or otherwise does not necessarily constitute or imply its endorsement, recommendation, or favoring by the United States Government or any agency thereof, or Battelle Memorial Institute. The views and opinions of authors expressed herein do not necessarily state or reflect those of the United States Government or any agency thereof.

\author{
PACIFIC NORTHWEST NATIONAL LABORATORY \\ operated by \\ BATTELLE \\ for the \\ UNITED STATES DEPARTMENT OF ENERGY \\ under Contract DE-ACO5-76RL01830
}

Printed in the United States of America

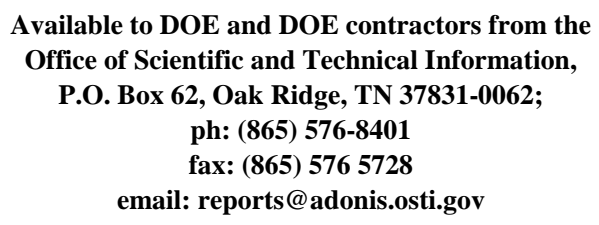

Available to DOE and DOE contractors from the Office of Scientific and Technical Information, P.O. Box 62, Oak Ridge, TN 37831-0062; ph: (865) 576-8401 fax: (865) 5765728

email: reports@adonis.osti.gov

\footnotetext{
Available to the public from the National Technical Information Service, U.S. Department of Commerce, 5285 Port Royal Rd., Springfield, VA 22161 ph: (800) 553-6847 fax: (703) 605-6900

email: orders@nits.fedworld.gov online ordering: http://www.ntis.gov/ordering.htm
} 


\title{
Urban Dispersion Program Overview and MID05 Field Study Summary
}

\author{
K. J. Allwine \\ J. E. Flaherty
}

July 2007

Prepared for the U.S. Department of Homeland Security under a Related Services Agreement with the U.S. Department of Energy under Contract DE-AC05-76RL01830

Pacific Northwest National Laboratory

Richland, Washington 99352 


\section{Summary}

The Urban Dispersion Program (UDP) was a 4-year project (2004-2007) funded by the U.S. Department of Homeland Security with additional support from the Defense Threat Reduction Agency. The U.S. Environmental Protection Agency (EPA) also contributed to UDP through funding a humanexposure component of the New York City (NYC) field studies in addition to supporting an EPA scientist in conducting modeling studies of NYC. The primary goal of UDP was to improve the scientific understanding of the flow and diffusion of airborne contaminants through and around the deep street canyons of NYC. The overall UDP project manager and lead scientist was Dr. Jerry Allwine of Pacific Northwest National Laboratory.

UDP had several accomplishments that included conducting two tracer and meteorological field studies in Midtown Manhattan. The first was a small-scale study that investigated dispersion in the immediate vicinity of Madison Square Garden during March 2005. The second UDP tracer and meteorological field study, designated as MID05, was an extensive study conducted during August 2005 in Midtown Manhattan. The MID05 study was unique in being the first extensive tracer study in Manhattan and, more importantly, the first study to investigate atmospheric transport and diffusion through the coupled outdoor-indoor-subway pathways in NYC.

To date, 56 publications, reports, and presentations have been completed documenting the various findings and accomplishments of UDP. Key accomplishments include:

- Conducting and documenting the two Midtown field studies

- Developing response guidance from findings of the two field studies and briefing NYC agencies as to the guidance

- Advancing mesoscale meteorological forecasting methods through ensemble techniques and advancing urban parameterizations of the surface energy balance

- Applying and evaluating computational fluid dynamics models and other building resolved models for application in the complex NYC urban environment

- Installing and operating a permanent meteorological network in and around Manhattan that includes state-of-the-art instruments for continuously measuring the winds as a function of height and providing the results graphically to responders.

This report gives a brief overview of the Urban Dispersion Program outlining the objectives, approach, organization, investigators, and main accomplishments. The report also provides documentation of the MID05 field study to facilitate the use of the meteorological and tracer data resulting from the study. Descriptions of the MID05 instruments, instrument locations, deployment schedule, and instrument operations are given. A summary of the meteorological conditions during the August 2005 study period is also provided. The MID05 tracer data (release rates and concentrations) currently have limited distribution (For Official Use Only) and will only be distributed on a need-to-know basis. This report does not give any quantitative tracer release or concentration information, so it is available for general distribution. 



\section{Acronyms}

AGL

ANL

ASOS

ATDD

BNL

BATS

CATS

CCNY

CFD

CPK

DoD

DOE

DOY

DHS

DPG

DTRA

ECD

EML

EPA

EST

FRD

GC

GIS

HSPH

IOP

LANL

LBNL

LLNL

MID05

MSG05

NERL

NGIT

above ground level

Argonne National Laboratory

automated surface observing system

Atmospheric Turbulence and Diffusion Division (Air Resources Laboratory)

Brookhaven National Laboratory

Brookhaven atmospheric tracer sampler

capillary adsorption tube sampler

City College of New York

computational fluid dynamics

Central Park

U.S. Department of Defense

U.S. Department of Energy

day of year

Department of Homeland Security

Dugway Proving Grounds

Defense Threat Reduction Agency

electron capture detector

Environmental Measurements Laboratory

U.S. Environmental Protection Agency

Eastern Standard Time

Field Research Division (NOAA Air Resources Laboratory)

gas chromatography

geographic information system

Harvard School of Public Health

intensive observation period

Los Alamos National Laboratory

Lawrence Berkeley National Laboratory

Lawrence Livermore National Laboratory

Midtown 2005

Madison Square Garden 2005

National Exposure Research Laboratory

Northrop Grumman Information Technology 
NOAA

NRL

NYC

NWS

OEM

PA

PI

PIGS

PFT

PNNL

SAS

SIT

SJSU

SUNY

SUNYSB

TGA

UDP
National Oceanic and Atmospheric Administration

Navy Research Laboratory

New York City

National Weather Service

Office of Emergency Management

public affairs +

principal investigator

programmable integrating gas sampler

perfluorocarbon tracer

Pacific Northwest National Laboratory

sequential air sampler

Stevens Institute of Technology

San Jose State University

State University of New York

State University of New York, Stony Brook

trace-gas analyzer

Urban Dispersion Program 


\section{Acknowledgments}

This research was supported in part by the U.S. Department of Homeland Security (DHS) under a Related Services Agreement with the U.S. Department of Energy (DOE) under Contract DE-AC0576RL01830. Pacific Northwest National Laboratory (PNNL) is operated for DOE by Battelle.

Numerous scientists, engineers, and students from several organizations, national laboratories, universities, and private companies contributed significantly to the Urban Dispersion Program (UDP) and to successfully accomplishing the two UDP field studies. We especially thank several individuals at the DHS Environmental Measurements Laboratory (EML) for helping launch UDP during early 2004, issuing all the necessary contracts to fund the team of investigators, and helping administer the program. The EML individuals are Mitch Erickson, Kevin Miller, Larry Ruth, Sam Lee, Adam Hutter, and Joe Caroli.

We also thank the team of PNNL staff who contributed to the success of UDP. These included Larry Berg, Peter Bengtson, Graham Parker, Karen Byers, Mikhail Pekour, Fred Rutz, Jeremy Rishel, Geoffrey Harvey, Susan Bauer, Chris Doran, Weiguo Wang, and Krystal Garza. We also acknowledge Larry Berg, Kirk Clawson of the National Oceanic and Atmospheric Administration's Air Resources Laboratory-Field Research Division, and Julie Pullen of the Naval Research Laboratory for the use of their photographs as figures in this report.

The UDP’s August 2005 Midtown Manhattan field study (MID05) would not have been possible without the support of many New York City (NYC) agencies, private land owners, universities, and the general public. Kevin Clark and Noel Keppler of the NYC Office of Emergency Management (OEM) were instrumental in the success of MID05 by spearheading many of the needed logistical arrangements and operating permissions. The support of Thomas Kiess, Dawn Myscofski, Teresa Lustig, Bruce Davis, and others at DHS was essential for the success of the field study specifically and UDP generally.

Completing the six intensive observation periods (IOPs) of the MID05 field study required the successful completion of several study components by specific project teams. The MID05 teams were the meteorology forecasting team, the three outdoor tracer teams, the building-top tracer team, the subway tracer team, the indoor study team, the near-field meteorology team, the boundary-layer meteorology team, the exposure-study team, and the public-affairs team.

The meteorological forecast team, led by Victor Cassella of Brookhaven National Laboratory and including Brian Colle of the State University of New York at Stonybrook and Michael Wylie of the National Weather Service, did an excellent job of providing accurate weather forecasts for making final "go/no-go" decisions 24-hours in advance of conducting field operations on a particular day. A study day began at about 4 AM Eastern Daylight Time (EDT) with deployment of the numerous instruments and tracer-release equipment in Midtown Manhattan in preparation for tracer releases and sampling to start at $7 \mathrm{AM}$ and extending through $1 \mathrm{PM}$. After completion of the sampling at $1 \mathrm{PM}$, the field teams retrieved the equipment and returned to their respective staging areas to organize and document the tracer samples, concluding their efforts around 5 to 6 PM.

The efforts of the nearly 200 members of the MID05 field teams enabled MID05 to be successfully accomplished, leading to an unparalleled data set documenting dispersion in Midtown Manhattan. The organizations conducting the MID05 field study were Pacific Northwest National Laboratory, 
Brookhaven National Laboratory (BNL), National Oceanic and Atmospheric Administration's (NOAA's) Air Resources Laboratory-Field Research Division (FRD), Argonne National Laboratory (ANL), Lawrence Livermore National Laboratory (LLNL), Lawrence Berkeley National Laboratory (LBNL), Northrop Grumman Information Technology (NGIT), NOAA’s Air Resources Laboratory-Atmospheric Turbulence and Diffusion Division (ATDD), Navy Research Laboratory, Stevens Institute of Technology, State University of New York (SUNY)-Stony Brook, The U.S. Environmental Protection Agency's (EPA's) Region II Office, the EPA's National Exposure Research Laboratory, and Rutgers University. Through the BNL University Program, numerous student and faculty from several local universities helped with conducting the MID05 study. The students and faculty were from Brooklyn College, City College of New York, Columbia University, Medgar Evers College, New York University, New York City College of Technology (NYCCT), SUNY—Binghamton, and SUNY—Potsdam. Noel Blackburn and Paul Kalb of BNL and Reggie Blake of NYCCT were instrumental in organizing and coordinating the university participation. The lead staff members for each MID05 field team were:

- BNL Outdoor Tracer Team-John Heiser and Tom Watson

- FRD Outdoor Tracer Team-Kirk Clawson and Roger Carter

- LLNL Outdoor Tracer Team-Marty Leach and Ron Pletcher

- Building-Top Tracer Team-Leo Stockham (NGIT)

- Subway Tracer Team—John Heiser (BNL), Paul Kalb (BNL) and Dave Brown (ANL)

- Indoor Study Team—Rich Sextro, Tracer Thatcher, and Woody Delp of LBNL

- Exposure Study Team—John Heiser (BNL), Dan Vallero (EPA), and Jim Daloia (EPA)

- Near-Field Meteorology Team-Mike Reynolds (BNL), Vic Cassella (BNL), Scott Smith (BNL), and Ray Hosker (ATDD)

- Boundary Layer Meteorology Team—Rich Coulter (ANL), Tim Martin (ANL), Larry Berg (PNNL), and Jerry Allwine (PNNL)

- Public Affairs Team-Peter Bengtson (PNNL) and Kay Cordtz (BNL).

The success of MID05 was especially dependent on having strategic equipment staging areas, parking spaces, meeting places, and a command center during field operations. The New Yorker hotel was very generous in providing ample meeting space and equipment staging areas for the study. Additionally, the NYC OEM provided a very aesthetic staging area for FRD tracer operations directly under the Brooklyn Bridge along the banks of the East River. Another generous contribution by NYC agencies for accomplishing the MID05 study was the use of a portion of the Jacqueline Onassis High School (JOHS) in the middle of the MID05 study area as the command center during field operations. The NYC Department of Education gave permission to use the facility, and JOHS staff provided the needed access to the building during study days.

And last but not least, the public affairs team, consisting of 12 individuals from various agencies and laboratories participating in MID05, handled the numerous media briefings, inquiries, and interviews, allowing the field staff to focus on conducting the field operations and yet provide important information to the public. 


\section{Contents}

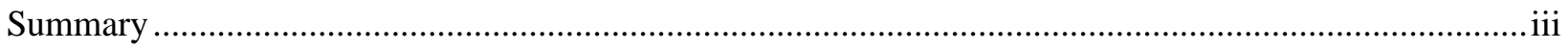

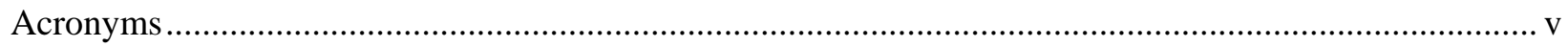

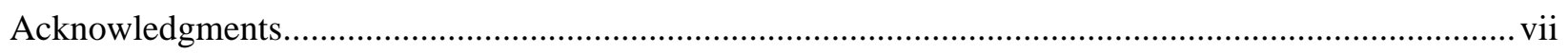

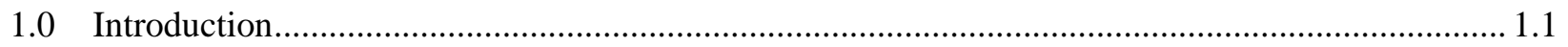

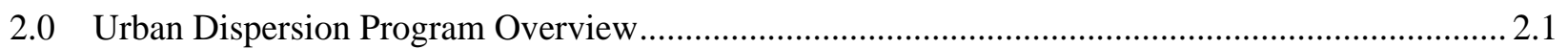

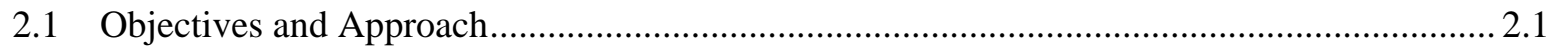

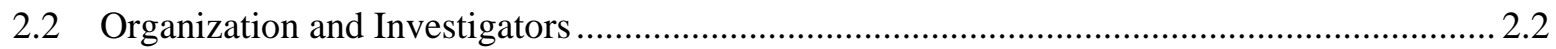

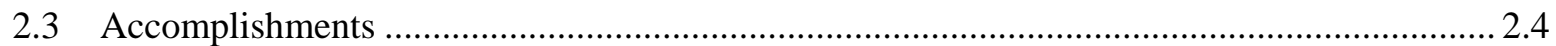

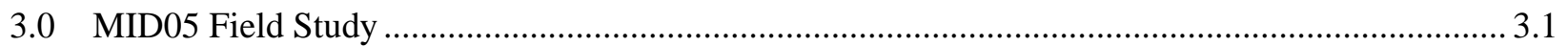

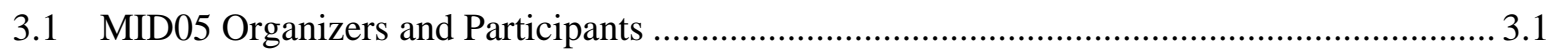

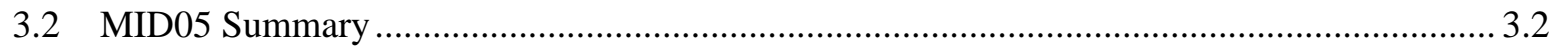

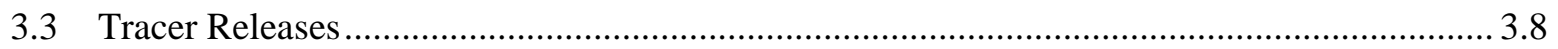

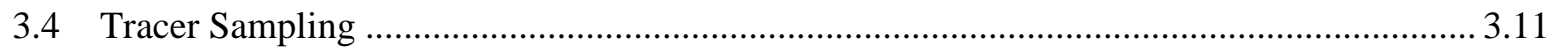

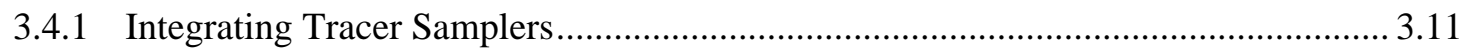

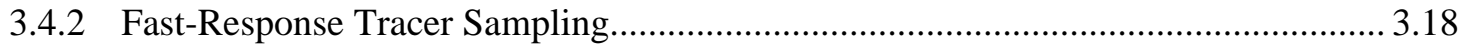

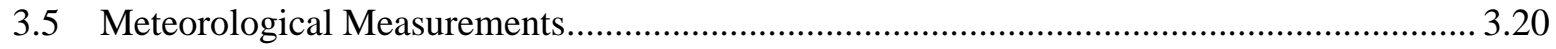

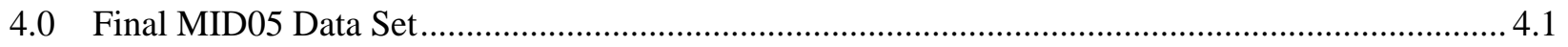

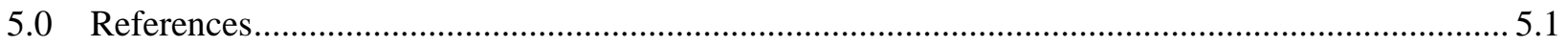

Appendix A: UDP Wrap-Up Memo and Publications .................................................................... A.1

A.1 UDP Wrap-Up Memorandum (June 1, 2007)................................................................. A.1

A.2 UDP Publications, Reports, and Presentations ….................................................................. A.3

Appendix B: Coordinates of MID05 Tracer Releases and Samplers......................................................1

Appendix C: Coordinates of MID05 Meteorological Instruments .......................................................... 


\section{Figures}

2.1. Urban Dispersion Program Organizational Chart.......................................................................... 2.2

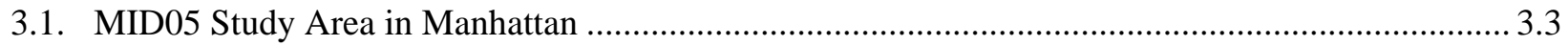

3.2. MID05 Tracer Release Locations and Street Names within the Study Domain............................. 3.4

3.3. Coverage of Tracer Releases and Sampling (top panel) and Meteorological Measurements (bottom panel) in the Manhattan study Area

3.4. Meteorological Measurements from a Weather Station on the top of the Lehman Brothers Building Located on the Northeast Corner of $49^{\text {th }}$ Street and $7^{\text {th }}$ Avenue During the MID05 Field Campaign

3.5. Avenue of the Americas ( $6^{\text {th }}$ Avenue) Looking South from Near $50^{\text {th }}$ Street and $6^{\text {th }}$ Avenue. 3.7

3.6. Photographs Looking West and East Along $49^{\text {th }}$ Street in the Vicinity of the CL Tracer Release Location.

3.7. Pictures of PFT and $\mathrm{SF}_{6}$ Tracer Release Equipment as Deployed During MID05.

3.8. Release Locations Within the $50^{\text {th }}$ Street Subway Station on the $1,2,3$ Line.

3.9. FRD 12-Position PIGS Sampler Collecting Air Samples into Bags (left side) and Adapted to Collecting Air Samples into Adsorption Tubes (right side)

3.10. BNL 20-Position SAS Sampler (left side) for Collecting Samples into CATS Tubes and a BNL 22-Position BATS Sampler (right side) for Collecting Samples onto Permanent Adsorption Tubes Contained in the Sampler lid.....

3.11. Locations of Street-Level Integrating Tracer Samplers Within the MID05 Study Domain.....

3.12. Rooftop Integrating Tracer Sampler Locations Within the MID05 Study Domain.

3.13. Subway Tracer Measurement Locations (blue dots) and Subway Releases (orange stars)

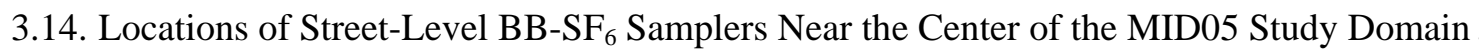

3.15. FRD Deployed Fast-Response $\mathrm{SF}_{6}$ Analyzer at Fixed Location in the Study Area Using Vans.... 3.19

3.16. Fast-Response $\mathrm{SF}_{6}$ Analyzers at Fixed Locations Deployed by FRD

3.17. Tracer Samplers as Deployed During MID05.

3.18. Meteorological Instruments Deployed During MID05.

3.19. Locations of Sonic Anemometers in the MID05 Study Domain 
3.20. Locations of Four Roof-Top Meteorological Stations (OPP, METL1, PPZ and GM1) and Two Roof-Top Sodars (METL2 and GM2) in the MID05 Study Domain

3.21. Locations of Existing Meteorological Stations (SIT3, EML, CPK and CCNY) in the NYC Area.

3.22. Locations of National Weather Service Stations in the Greater NYC Region 3.24

3.23. MID05 HOBO® Temperature Sensor Positions

3.25

\section{Tables}

2.1. Science Team Principal Investigators (PIs), Tasks and Primary Program Responsibilities....

3.1. Summary of Meteorological Conditions During MID05 Experimental Days

3.2. Acronyms, Chemical Names, Chemical Formulae, Molecular Weights and Background Concentrations of Perfluorocarbon Tracers and Sulfur Hexafluoride Tracer Used in the MID05 Study

3.3. Descriptions of MID05 Outdoor and Subway Tracer Release Locations and Names of Tracers Released.

3.4. Summary of MID05 Tracer Releases

3.5. Number of Integrating Tracer Samplers, Averaging Time (AVE) in Minutes and Sampling Period (EST)

3.6. Deployment of Roof-Top Tracer Samplers for each IOP by Sampler Type Where "S" Denotes an SAS-PFT Sampler (five or seven units), "B” a BB-SF 6 Sampler (four units) and "Px" a PIGS-SF 6 Sampler (four units).

B.1. MID05 Release Location Coordinates.

B.2. Street-Level Integrating Tracer Sampler Coordinates

B.3. Rooftop Integrating Tracer Sampler Coordinates

B.4. Coordinates of 8 BATS-PFT Integrating Tracer Samplers Located at Various Subway Stations in Midtown.

B.5. Coordinates for BlueBox Integrating Samplers $\left(\mathrm{BB}_{-} \mathrm{SF}_{6}\right)$ and Miran Analyzers

B.6. Coordinates of Fixed FRD Fast-Response $\mathrm{SF}_{6}$ Analyzers by IOP and Release Number B.6

C.1. Meteorological Instrument Coordinates During MID05 .C.1

C.2. HOBO Positions During MID05. 


\subsection{Introduction}

Air motions in and around cities are highly complex, and the increasing threat of harmful releases into urban atmospheres makes it essential to advance the state-of-science of understanding and modeling atmospheric flows and dispersion in and around cities. The 4-year (2004-2007) Urban Dispersion Program (UDP), funded primarily by the U.S. Department of Homeland Security (DHS) with contributions from the Defense Threat Reduction Agency (DTRA), has recently been completed. The program's primary focus was to conduct two tracer and meteorological field studies in Manhattan to improve our understanding of flow and dispersion of airborne contaminants through and around the deep street canyons of New York City (NYC), including outdoor-indoor-subway exchange mechanisms.

Field studies are vitally important for improving and validating atmospheric models that simulate contaminant dispersion in and around cities. These models are used by emergency management, law enforcement, and intelligence personnel to effectively plan for and respond to potential terrorist attacks and accidents. Dr. Jerry Allwine of Pacific Northwest National Laboratory (PNNL) led investigators from several government laboratories, universities, and private companies in conducting the two UDP field studies. The first study was a small-scale study that investigated dispersion in the immediate vicinity of Madison Square Garden during March 2005 (MSG05), while the second was an extensive study conducted during August 2005 in Midtown Manhattan (MID05). The MID05 field study expands on the information gathered from similar tracer studies conducted in smaller cities such as Oklahoma City (Allwine et al. 2004) and Salt Lake City (Allwine et al. 2002), as well as the insights gained from the MSG05 experiment.

Another key UDP objective, in addition to completing the two field studies, was to enhance NYC's emergency-response capabilities for addressing potential airborne releases of harmful materials. This was accomplished by evaluating and improving mesoscale meteorological models and urban dispersion models, and by installing a state-of-the-art meteorological network in and around Manhattan, providing meteorological data in near-real time to NYC emergency responders. Section 2 of this report gives a brief overview of the Urban Dispersion Program and a list of its significant accomplishments. The remainder of this report provides detailed documentation of the MID05 field study and will serve as the primary reference for that study. The MSG05 study will not be discussed in this report, but details about this study can be found in Allwine and Flaherty (2006), Watson et al. (2006), and Reynolds (2006).

Note that the MID05 tracer data (release rates and concentrations) currently have limited distribution (For Official Use Only) and will only be distributed on a need-to-know basis. This report does not give any quantitative tracer release or concentration information, so it is available for general distribution. 


\subsection{Urban Dispersion Program Overview}

The Urban Dispersion Program was a 4-year research program (2004-2007) funded primarily by DHS with the primary goal of investigating air flow and atmospheric dispersion through the borough of Manhattan in NYC. The UDP collected ground-truth dispersion data that will be used to develop and validate tools to aid planners and first responders in the event of a contaminant release into the atmosphere of Manhattan.

The UDP was formed during 2004 because of the lack of understanding of atmospheric dispersion in large cities and the paucity of airborne dispersion data for large cities generally and NYC specifically. This section of the report gives a brief overview of UDP, outlining the objectives, approach, organization, investigators, and main accomplishments.

\subsection{Objectives and Approach}

The primary objectives of UDP were to enhance NYC's emergency capabilities for addressing potential airborne releases of harmful materials, compare and validate urban parameterizations for atmospheric dispersion models by advancing our understanding and characterization of urban effects on dispersion in large cities, and further our understanding and characterization of outdoor-indoor-subway exchange by conducting coupled indoor-outdoor-subway tracer studies. An important secondary objective was to assess the general applicability of UDP findings and technologies to other urban areas. Specific objectives of the UDP were:

- Improve the permanent meteorological network in and around NYC to allow better estimates of where contaminants may travel

- Conduct field studies in NYC to advance knowledge about the movement of contaminants in and around large cities and into and within building interiors and subways

- Improve and validate computer models that simulate the atmospheric movement of contaminants in urban areas using data collected from the field studies

- Transfer the improved capabilities to NYC emergency agencies.

The basic approach in accomplishing the objectives of UDP was to collaborate with other federal agencies (DTRA, U.S. Environmental Protection Agency [EPA], U.S. Department of Energy [DOE], and the National Oceanic and Atmospheric Administration [NOAA]), to build on recent urban dispersion modeling and field efforts, and to work closely with the NYC Office of Emergency Management (OEM) to address some of their immediate and long-term needs. UDP objectives were accomplished by a team of national experts in urban field studies, urban meteorology, and atmospheric modeling by completing four tasks:

1) Complete permanent meteorological network

2) Conduct urban meteorology and tracer studies

3) Apply, evaluate, and improve meteorological and dispersion models

4) Transfer technology to NYC agencies. 


\subsection{Organization and Investigators}

UDP was accomplished with the close interaction of three project teams (Management, Science, and Public Affairs) and the NYC OEM. Figure 2.1 shows the interactions of the various teams and their members. The Management Team, consisting of DHS and DTRA program managers and the OEM lead, had program oversight, authorized funding and facilitated multi-agency involvement. A subgroup (Coordinate Programs) of the management team were individuals available to participate in management team meetings to provide continuity with other related programs. The Science Team consisted of all funded principal investigators and was responsible for successfully undertaking and completing the project. The Public Affairs (PA) Team, which comprised PA staff from each agency, was responsible for the public outreach describing the UDP field efforts. Because of the need to place test equipment and release tracer gasses in and around Manhattan, successfully accomplishing UDP was critically dependent on the support of the City of New York, generally, and specifically OEM.

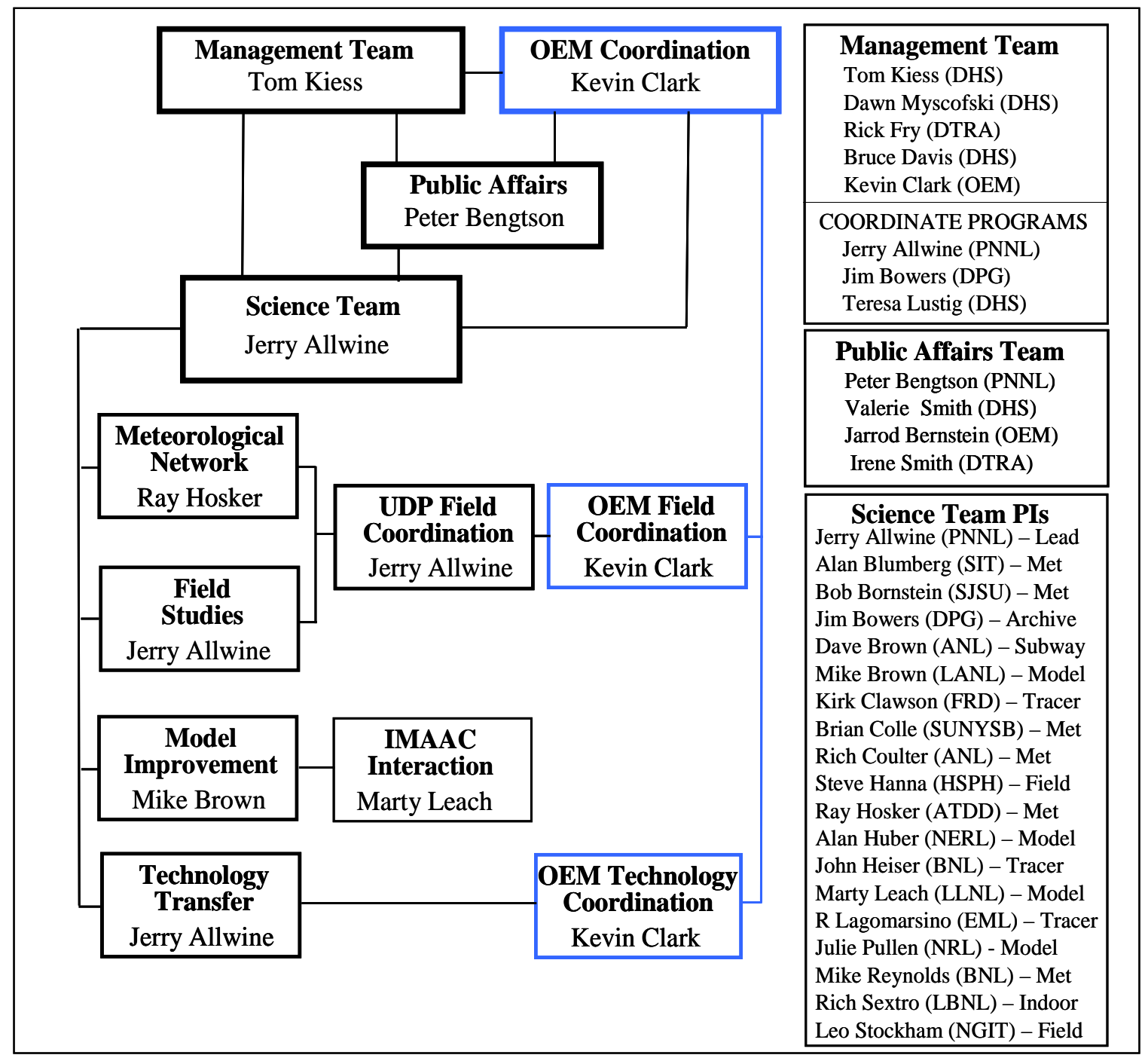

Figure 2.1. Urban Dispersion Program Organizational Chart. 
Table 2.1 lists the principal investigators on the Science Team and their primary responsibilities by task (tasks are listed in Section 2.1). The bold " $\mathbf{X}$ " in the table denotes the task lead. The Science Team consists of investigators from seven DOE/DHS laboratories, four universities, three U.S. Department of Defense (DoD) laboratories, two NOAA laboratories and one EPA laboratory. Administrative staff from DHS Environmental Measurements Laboratory (EML) issued and administered all contracts needed to conduct the first two years of UDP efforts. PNNL administrative staff tracked budgets, reporting and milestones for UDP.

Table 2.1. Science Team Principal Investigators (PIs), Tasks and Primary Program Responsibilities. (Tasks 1 to 4 are listed in Section 2.1)

\begin{tabular}{|c|c|c|c|c|c|c|}
\hline \multirow[b]{2}{*}{ PI } & \multirow[b]{2}{*}{ LAB* } & \multicolumn{4}{|c|}{ TASKS } & \multirow{2}{*}{$\begin{array}{c}\text { PRIMARY } \\
\text { RESPONSIBILITIES }\end{array}$} \\
\hline & & 1 & 2 & 3 & 4 & \\
\hline Allwine & PNNL & $\mathrm{x}$ & $\mathbf{X}$ & & $\mathbf{X}$ & $\begin{array}{l}\text { Program management; Scientific lead; Tracer studies lead; } \\
\text { Technology transfer lead }\end{array}$ \\
\hline Blumberg & SIT & $\mathrm{x}$ & & & & $\begin{array}{l}\text { Interface Urban Ocean Observatory network with } \\
\text { Meteorological network }\end{array}$ \\
\hline Bornstein & SJSU & $\mathrm{x}$ & & $\mathrm{x}$ & & Characterize meteorology; Urbanized MM5 \\
\hline Bowers & DPG & & $\mathrm{x}$ & & & Develop and maintain data archive \\
\hline D. Brown & ANL & & $\mathrm{x}$ & & $\mathrm{X}$ & Field measurements in subway \\
\hline M. Brown & LANL & & & $\mathbf{X}$ & $\mathrm{x}$ & Modeling task lead; Develop building data bases \\
\hline Colle & SUNYSB & & $\mathrm{x}$ & $\mathrm{x}$ & & Mesoscale forecasting and meteorological characterization \\
\hline Coulter & ANL & $\mathrm{x}$ & $\mathrm{x}$ & & & Remote sensing of winds using sodars and radars \\
\hline Clawson & FRD & & $\mathrm{x}$ & & & Tracer studies design and major participation \\
\hline Hanna & HSPH & & $\mathrm{x}$ & & & MSG05 design; Tracer studies design and data analysis \\
\hline Heiser & BNL & & $\mathrm{x}$ & & & PFT tracer in field studies \\
\hline Hosker & ATDD & $\mathbf{X}$ & $\mathrm{x}$ & & $\mathrm{x}$ & $\begin{array}{l}\text { Meteorological task lead; Long-term networks; Tracer } \\
\text { studies; Help formulate data transmission/viewing systems }\end{array}$ \\
\hline Huber & NERL & & & $\mathrm{x}$ & & CFD modeling and interface to EPA NYC efforts \\
\hline Lagomarsino & EML & & $\mathrm{x}$ & & & Oversight of tracer data quality control \\
\hline Leach & LLNL & & $\mathrm{x}$ & $\mathrm{x}$ & & $\begin{array}{l}\text { Characterize meteorology; COAMPS simulations; Tracer } \\
\text { studies design and participation; IMAAC interface }\end{array}$ \\
\hline Pullen & NRL & & & $\mathrm{x}$ & & Improve lower boundary conditions (water T) to models \\
\hline Reynolds & BNL & $\mathrm{x}$ & $\mathrm{x}$ & & & $\begin{array}{l}\text { Lead field instillation of met. network including roof-top } \\
\text { and street canyon stations; Help formulate data } \\
\text { transmission/viewing systems; Met instruments in field }\end{array}$ \\
\hline Sextro & LBNL & & $\mathrm{x}$ & & $\mathrm{x}$ & $\begin{array}{l}\text { Coordinate all indoor field studies efforts; Tracer studies } \\
\text { design and participation }\end{array}$ \\
\hline Stockham & NGIT & & $\mathrm{x}$ & & & Field logistical and data coordinator \\
\hline \multicolumn{7}{|c|}{$\begin{array}{l}\text { * PNNL - Pacific Northwest National Laboratory; SIT - Stevens Institute of Technology; SJSU - San Jose } \\
\text { State University; DPG - Dugway Proving Grounds; ANL - Argonne National Laboratory; LANL - Los } \\
\text { Alamos National Laboratory; SUNYSB - State University of New York, Stony Brook; FRD - NOAA Air } \\
\text { Resources Laboratory Field Research Division; HSPH - Harvard School of Public Health; BNL - } \\
\text { Brookhaven National Laboratory; ATDD - NOAA Air Resources Laboratory-Atmospheric Turbulence } \\
\text { and Diffusion Division; NERL - EPA-National Exposure Research Laboratory; EML - DHS } \\
\text { Environmental Measurements Laboratory; LLNL - Lawrence Livermore National Laboratory; NRL - } \\
\text { Navy Research Laboratory; LBNL - Lawrence Berkeley National Laboratory; NGIT - Northrop Grumman } \\
\text { Information Technology. }\end{array}$} \\
\hline
\end{tabular}




\subsection{Accomplishments}

Several important contributions fostering improved planning and response to harmful airborne materials released in urban areas were made by the Urban Dispersion Program. Most important was the accomplishment of two unique tracer and meteorological field studies (MSG05 and MID05) conducted in the complex urban environment of Midtown Manhattan. The studies were unique in being the first tracer studies in Manhattan and, more importantly, in investigating atmospheric transport and diffusion through the coupled outdoor-indoor-subway pathways in NYC. The data have been used to help formulate guidance in responding to airborne release in Midtown and in evaluating and improving urban dispersion models. Data archives of the final quality assured tracer and meteorological data have been completed and are available from the authors. The MSG05 tracer data are generally available because no new fundamental insights were gained in urban dispersion under the high-wind speed cases investigated. However, the MID05 tracer data are "For Official Use Only" and have limited distribution on a need-toknow basis because the MID05 study was much more extensive than the MSG05 study and contained findings on transport through the subway system.

In addition to completing and documenting the two Midtown field studies, other significant efforts accomplished by UDP investigators include:

- Developing first-responder guidance from findings of the two field studies and briefing NYC agencies on the guidance

- Advancing mesoscale meteorological forecasting methods through ensemble techniques

- Improving and evaluating urban parameterizations in mesoscale meteorological models

- Improving our understanding of the characteristics of sea breezes in the vicinity of NYC

- Applying and evaluating computational fluid dynamics (CFD) models and other buildingresolved models for application in the complex NYC urban environment

- Evaluating the turbulence characteristics and dispersion potential of flows within Manhattan

- Improving and refining the representation of NYC building geometries and other geographic information for use in data analysis and as input to models

- Advancing multiple-tracer techniques for conducting coupled outdoor-indoor-subway studies

- Installing a permanent meteorological network in and around Manhattan that includes state-ofthe-art instruments for continuously measuring the winds as a function of height

- Archiving and displaying the meteorological data from the permanent network in near-real time for use by NYC first responders.

The email memorandum dated June 1, 2007 from Dr. Tomas Kiess announcing the completion of UDP is given in Appendix A along with the list of the 56 publications, reports and presentations completed to date within UDP. 


\subsection{MID05 Field Study}

The MID05 study was unique in that it was the first extensive tracer and meteorological field study investigating outdoor-indoor-subway dispersion in the borough of Manhattan in NYC. The study was conducted in Midtown Manhattan during the period August 8-26, 2005. This section of the report identifies the numerous organizations contributing to the MID05 study, an overview of the study including the meteorological conditions during the study period, details about the tracer releases and sampling, and details about the meteorological measurements during the study period. Appendices B and $\mathrm{C}$ list the coordinates of all the tracer and meteorological instrument deployed during MID05. Most coordinates listed are accurate to within $2 \mathrm{~m}$ with some (e.g., subway releases and samplers) accurate to within $10 \mathrm{~m}$.

The MID05 tracer data (release rates and concentrations) are currently considered "For Official Use Only" and are not available for public distribution or publication. The data will be distributed on a needto-know basis, and any results derived from analysis of the data will be subject to review and may be limited in publication and distribution. This report does not give any quantitative tracer release or concentration information, so it is available for general distribution.

\subsection{MID05 Organizers and Participants}

The August 2005 Midtown Manhattan field study was a major scientific and logistical effort that involved nearly 200 scientists, engineers, technicians, and students. The overall field effort was led by Dr. Jerry Allwine of Pacific Northwest National Laboratory. The NYC Office of Emergency Management was the lead NYC organization helping to arrange all logistics and permissions for accomplishing the study. The coordination effort was led by Mr. Kevin Clark and his staff of OEM. Mr. Clark and his staff coordinated all meetings and contacts allowing the MID05 field organizers to successfully conduct the study. The NYC agencies that helped arrange MID05 were OEM, NYC Police Department, Metropolitan Transportation Authority, Department of Education, Department of Transportation, Department of Health and Mental Hygiene, and Manhattan community boards. Several private property owners, property managers and business organizations allowed meteorological and tracer equipment to be placed around and on their buildings in Midtown Manhattan. Additionally, the New Yorker Hotel accommodated many of the MID05 scientists and engineers and provided meeting space for the several coordination and public outreach meetings required to accomplish the very visible MID05 field study.

In addition to the scientific personnel involved, numerous non-scientific support personnel were involved in making this a successful field study. As we learned in previous field experiments, public affairs were a key element of conducting a successful field campaign. The NYC OEM, DHS, and EPA each had PA staff involved in this experiment, while PNNL provided a team of PA coordinators that served as lead points-of-contact for media and citizen questions and concerns. The news media provided information about this field program before and during the experimental periods to ensure that the public was aware of, and felt comfortable about the use of their city for this investigation.

The NYC Police Department was also kept well-informed of project activities. Each of the project participants wore identification badges during study periods, and a list of all the participants was 
delivered to the Police Department so they could further identify the individuals involved in the study for safety and security purposes.

Organizations participating in the MID05 field efforts included DOE and DHS national laboratories, NOAA laboratories, DoD laboratories, EPA, private companies, and a number of colleges and universities. The organizations participating in MID05 were:

\section{DHS and DOE National Laboratories}

- ANL

- BNL

- LBNL

- LLNL

- PNNL

NOAA Laboratories

- ATDD

- FRD

Private Companies

- Northrup Grumman Information Technology
Educational Institutions

- SIT

- Rutgers University

- Brooklyn College

- City College of New York (CCNY)

- Columbia University

- Medgar Evers College

- New York University

- NYC College of Technology

- State University of New York (SUNY)

EPA Laboratories

- NERL

- EPA Region II

DoD Laboratory

- NRL

\subsection{MID05 Summary}

The MID05 tracer and meteorological field study was conducted in Midtown Manhattan in an approximately 2-km-by-2-km domain centered to the south of Central Park (Figure 3.1) from approximately $36^{\text {th }}$ Street to $61^{\text {st }}$ Street south to north, and from $10^{\text {th }}$ Avenue to $3^{\text {rd }}$ Avenue west to east.

This study was designed to examine the dispersion of airborne materials through the deep street canyons, into a modern office building and through the subways. A human exposure component of MID05 was also conducted on one day of the study by EPA. This component of MID05 will not be discussed in this report. MID05 comprised of six intensive observation periods (IOPs), where each IOP was conducted from 0600 to 1200 Eastern Standard Time (EST). During an IOP, six safe, inert, gaseous perfluorocarbon tracers (PFTs) and sulfur hexafluoride $\left(\mathrm{SF}_{6}\right)$ tracer were simultaneously released from a number of locations, including outdoor street-level locations, within a building and in the subway.

Figure 3.2 shows the tracer release locations on a detailed map of Midtown with street names. The tracer releases are discussed in more detail in Section 3.3. Each IOP consisted of three tracer release periods of 30-minutes each beginning at 6, 8 and 10 AM EST. Tracer measurements were made using a total of 158 integrating tracer samplers and 9 fast-response tracer analyzers deployed at street-level on an 8-by-8 grid covering the study domain, at 19 street-level locations within an approximate 2-block area near $49^{\text {th }}$ Street and $6^{\text {th }}$ Avenue, at 15 rooftop locations within the study domain, and at 8 locations in the subway. 

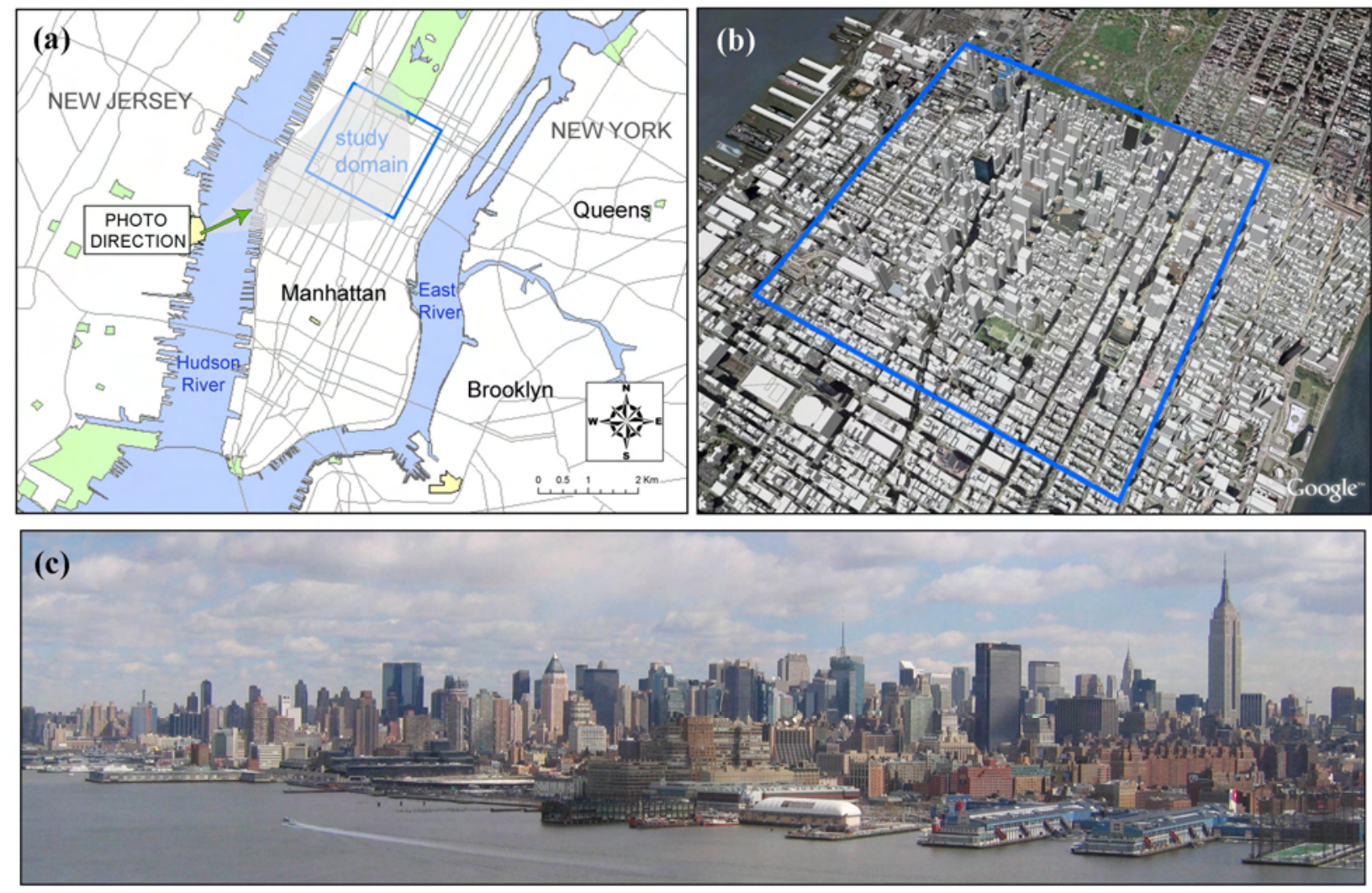

Figure 3.1. MID05 Study Area in Manhattan. The blue box in Panel (a) shows the 2-km-by-2-km MID05 study domain, and Panel (b) shows the domain in an aerial perspective of Midtown Manhattan extending from the Hudson River on the west to the East River on the east. The domain is just south of Central Park. The skyline of the Midtown study area is shown in Panel (c) where the photograph is taken from the Stevens Institute of Technology in New Jersey. Panel (a) shows the photograph direction.

In addition to collecting tracer data, meteorological measurements at a number of locations were accomplished to support this study. Sonic anemometers were deployed on five building rooftops, two building setbacks and 10 street-level locations in Midtown for this study. An additional three permanent rooftop anemometer locations in Manhattan and one in Hoboken, New Jersey, collected data that were available to support this field study. Furthermore, vertical profiles of winds were measured with two sodars deployed in Midtown Manhattan, and a radar wind profiler and radiosonde launches that were deployed in Hoboken at SIT. Temperatures in Midtown were also measured at 17 locations distributed from the East River to the Hudson River, and from $28^{\text {th }}$ Street into Central Park. Lastly, nearby Automated Surface Observing Stations (ASOS), operated by the National Weather Service (NWS), and located at airports and in Central Park, completed the available meteorological measurements. Figure 3.3 shows the general coverage of the tracer releases and sampling, and the meteorological measurements for MID05 in the NY-NJ vicinity of NYC. 


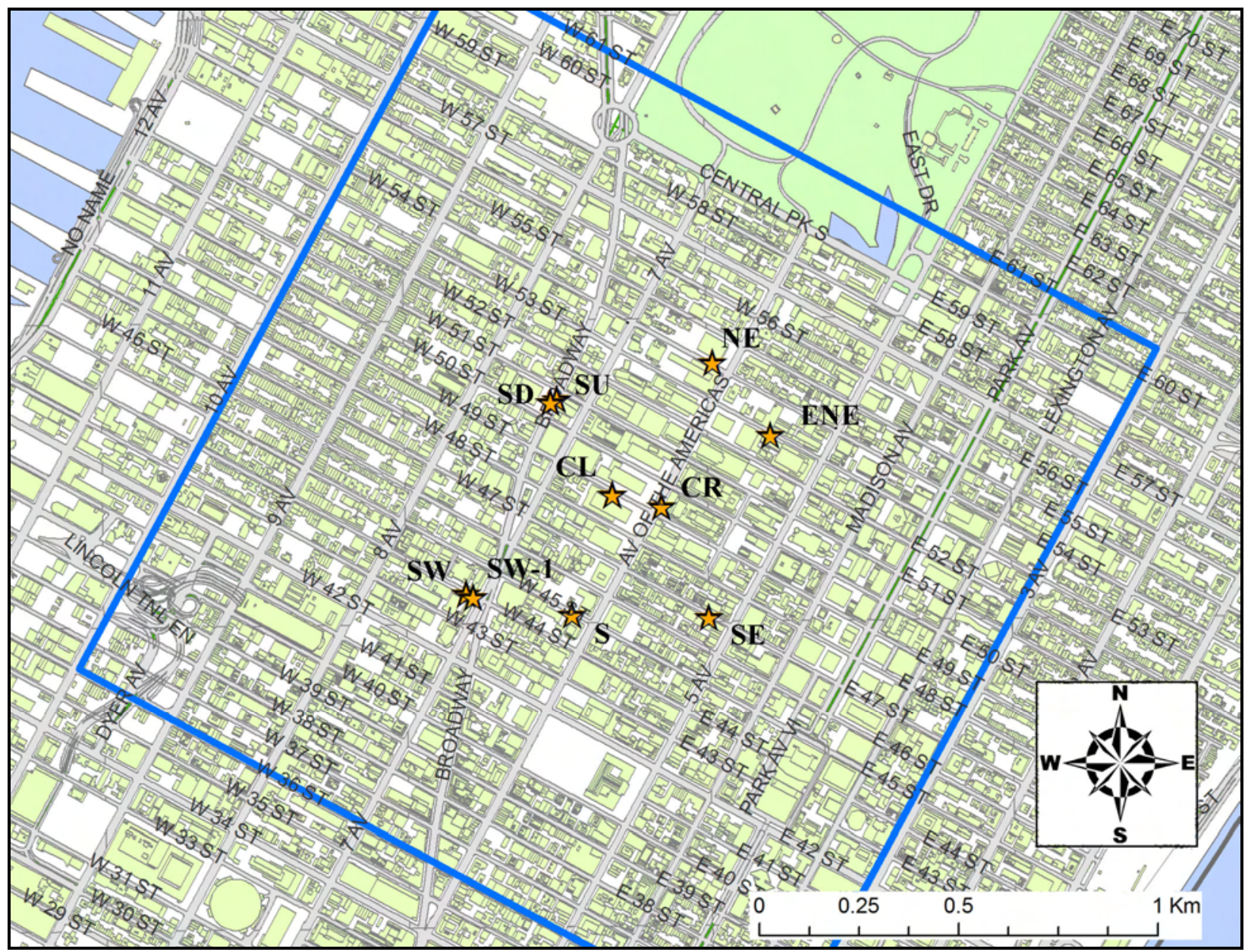

Figure 3.2. MID05 Tracer Release Locations and Street Names within the Study Domain. Orange stars represent the tracer release positions, while the blue border represents the study domain. The labels of the release positions are: NE - northeast, ENE - east-northeast, CL - center left, CR - center right, SW - southwest, SW-1 - southwest-1, S - south, SE - southeast, SU - subway-uptown and SD - subway-downtown. (See Section 3.3 for more detail on the tracer releases.)

The general meteorology during the MID05 field study is characterized by the time series plots of meteorological conditions for one station (on top of the Lehman Brothers Building; located at $49^{\text {th }}$ Street and $7^{\text {th }}$ Avenue) in Midtown. The time-series plots of wind speed, wind direction, temperature and relative humidity measured at the Lehman Brothers Building are shown in Figure 3.4. The plot of sealevel pressure given in Figure 3.4 is from the National Weather Service station in Central Park. The light blue bars in the figure indicate the times of the six IOPs conducted during the August 8-26, 2007 period.

Meteorological conditions during the IOPs were typically warm and humid with temperatures ranging from 20 to $30{ }^{\circ} \mathrm{C}$ and humidity levels between 50 and $80 \%$. Winds were generally below $5 \mathrm{~m} \mathrm{~s}^{-1}$ at the building top through the duration of the field study. Because of some $\mathrm{SF}_{6}$ local sources (electrical substations) in the Midtown area, IOPs were conducted when the winds were from the $250^{\circ}$ sector extending from north-northwest clockwise through southwest to avoid the local sources contaminating the Midtown study area. IOPs were not conducted when the winds were from any other direction. 
Additionally, IOPs were not conducted during inclement weather for safety of field staff deploying equipment on some Midtown buildings. The meteorological conditions during each IOP are summarized in Table 3.1.
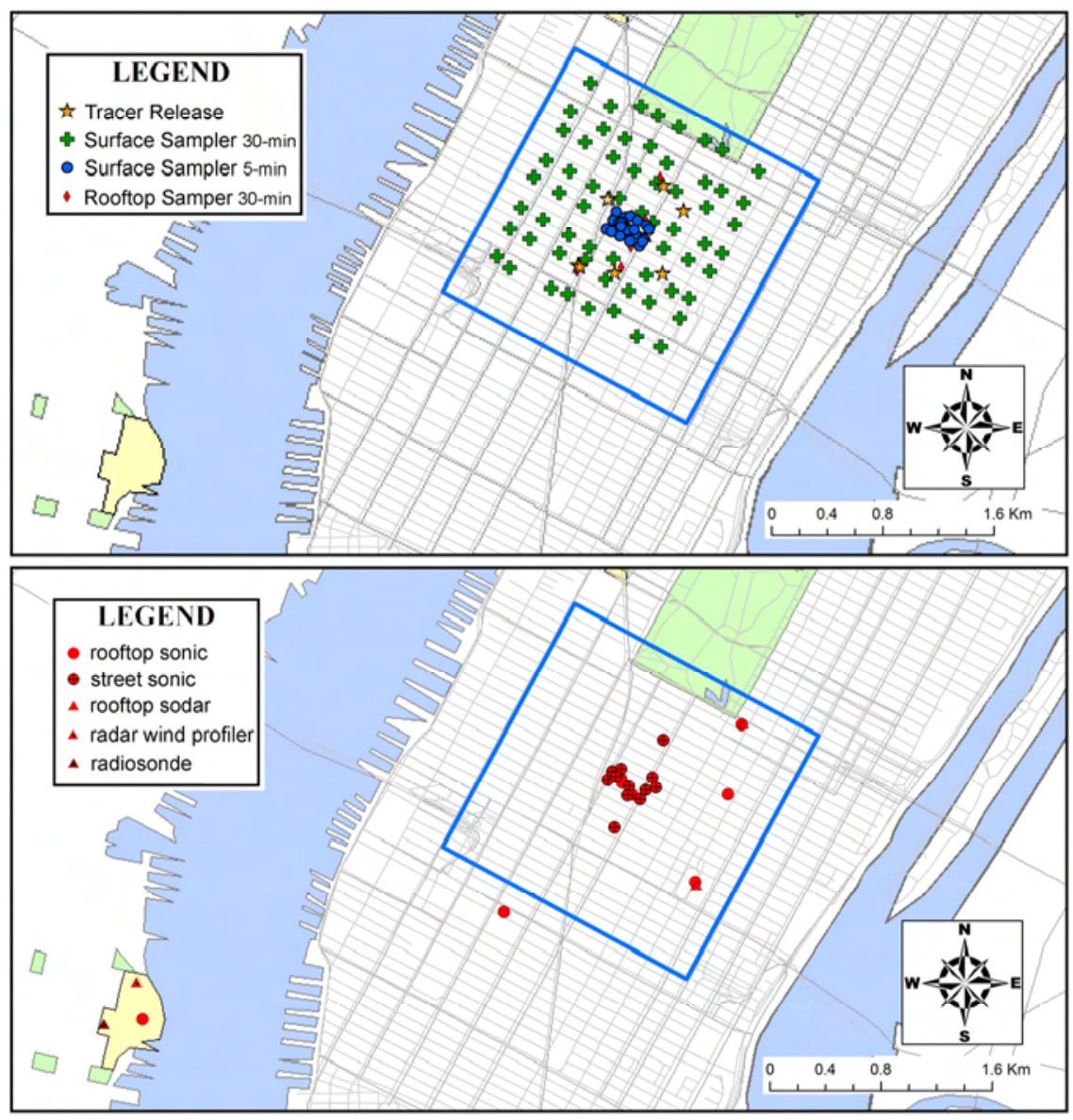

Figure 3.3. Coverage of Tracer Releases and Sampling (top panel) and Meteorological Measurements (bottom panel) in the Manhattan study Area. The blue box shows the 2-km-by-2-km MID05 study domain.

As shown in Figure 3.3 a high density of tracer and meteorological measurements occurred near the center of the study domain generally within the area from $6^{\text {th }}$ Avenue to $7^{\text {th }}$ Avenue and from $48^{\text {th }}$ Street to $51^{\text {st }}$ Street. This area includes several buildings over 200 meters in height and is an area of Midtown with very deep street canyons. Figure 3.5 identifies three tall buildings (1211, 1221 and 1251 Avenue of the Americas) on the west side of $6^{\text {th }}$ Avenue (Avenue of the Americas) extending from $47^{\text {th }}$ to $50^{\text {th }}$ Street. This area of Midtown contained the "CL" and "CR" tracer release locations from which tracers were released during all six IOPs. In fact, the CL release location identified in Figure 3.2 is on the south side of $49^{\text {th }}$ Street between the 1221 and 1251 Avenue of the Americas buildings just to the west of $6^{\text {th }}$ Avenue. The CL site is approximately one-third-of-the-way from $6^{\text {th }}$ Avenue to $7^{\text {th }}$ Avenue (going west) along $49^{\text {th }}$ Street. Figure 3.6 shows the view west and east along $49^{\text {th }}$ Street from the CL release location. As can be seen from the photographs the release is located on a plaza in front of the $49^{\text {th }}$ Street entrance to the 1221 Avenue of the Americas building. 


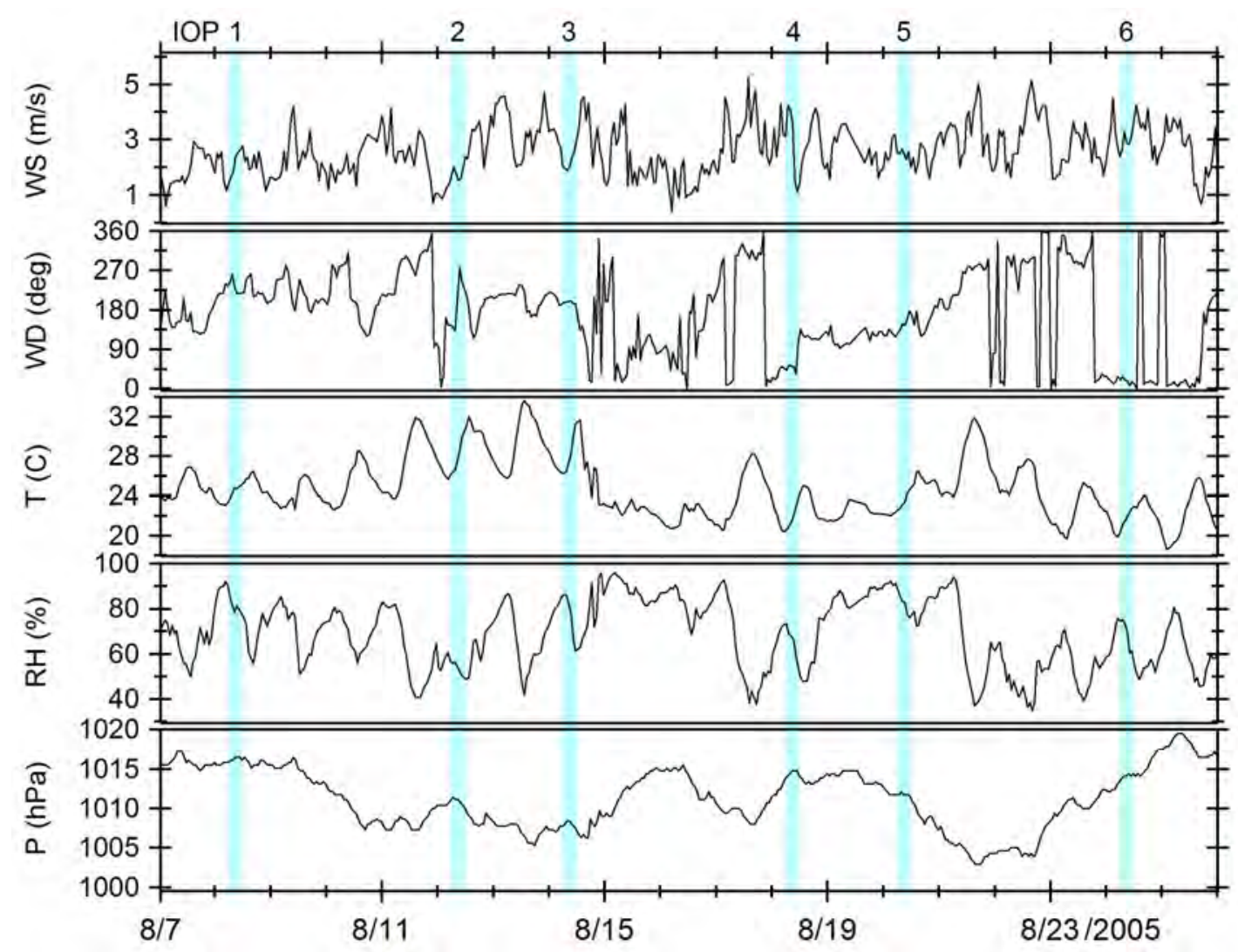

Figure 3.4. Meteorological Measurements from a Weather Station on the top of the Lehman Brothers Building Located on the Northeast Corner of $49^{\text {th }}$ Street and $7^{\text {th }}$ Avenue During the MID05 Field Campaign. The data are 1-h averages and the light blue bars indicate the 6-h-long IOPs. WS=wind speed, $\mathrm{WD}=$ wind direction, $\mathrm{T}=$ temperature, $\mathrm{RH}=$ relative humidity, and $\mathrm{P}=$ pressure. The pressure measurements are from the National Weather Service station located in Central Park.

Table 3.1. Summary of Meteorological Conditions During MID05 Experimental Days. Measurements are from a weather station on top of the Lehman Brothers Building in Midtown Manhattan.

\begin{tabular}{|c|c|c|}
\hline IOP & Date & "Weather Conditions \\
\hline 1 & $\begin{array}{l}\text { 8/8/2005 } \\
\text { Monday }\end{array}$ & $\begin{array}{l}\text { Light and steady winds from the southwest at } 1-2 \mathrm{~m} \mathrm{~s}^{-1} \text {. Temperatures in the mid } \\
\text { to upper } 20 \mathrm{~s}^{\circ} \mathrm{C} \text {. Mostly cloudy. }\end{array}$ \\
\hline 2 & $\begin{array}{c}\text { 8/12/2005 } \\
\text { Friday }\end{array}$ & $\begin{array}{l}\text { Light and variable winds from east-northeast at } 1-2 \mathrm{~m} \mathrm{~s}^{-1} \text { shifted to a southwest sea } \\
\text { breeze between } 8 \text { to } 9 \text { AM EST. Temperatures in the mid 20s to low } 30 \mathrm{~s}^{\circ} \mathrm{C} \text {. } \\
\text { Partly cloudy. }\end{array}$ \\
\hline 3 & $\begin{array}{c}8 / 14 / 2005 \\
\text { Sunday }\end{array}$ & $\begin{array}{l}\text { Moderate and steady south to southwest winds at } 3-4 \mathrm{~m} \mathrm{~s}^{-1} \text {. High temperatures; } \\
\text { low to mid 30s }{ }^{\circ} \mathrm{C} \text {. Partly cloudy. }\end{array}$ \\
\hline 4 & $\begin{array}{l}\text { 8/18/2005 } \\
\text { Thursday }\end{array}$ & $\begin{array}{l}\text { Strong northeast winds from } 5-7 \mathrm{~m} \mathrm{~s}^{-1} \text { through } 8 \text { AM EST, slowing to } 3 \mathrm{~m} \mathrm{~s}^{-1} \text { by } \\
11 \text { AM EST. Temperatures were in the mid } 20 \mathrm{~s}{ }^{0} \mathrm{C} \text {. Partly cloudy. }\end{array}$ \\
\hline 5 & $\begin{array}{l}8 / 20 / 2005 \\
\text { Saturday }\end{array}$ & $\begin{array}{l}\text { Moderate and steady winds from the south to south-southwest at } 3 \mathrm{~m} \mathrm{~s}^{-1} \text {. } \\
\text { Temperatures in mid to upper } 20 \mathrm{~s}^{\circ} \mathrm{C} \text {. Overcast skies. }\end{array}$ \\
\hline 6 & $\begin{array}{l}\text { 8/24/2005 } \\
\text { Wednesday }\end{array}$ & $\begin{array}{l}\text { Strong and steady winds from the north at } 4-5 \mathrm{~m} \mathrm{~s}^{-1} \text {. Temperatures in low to mid } \\
\text { 20s }{ }^{\circ} \mathrm{C} \text {. Mostly clear skies. }\end{array}$ \\
\hline
\end{tabular}



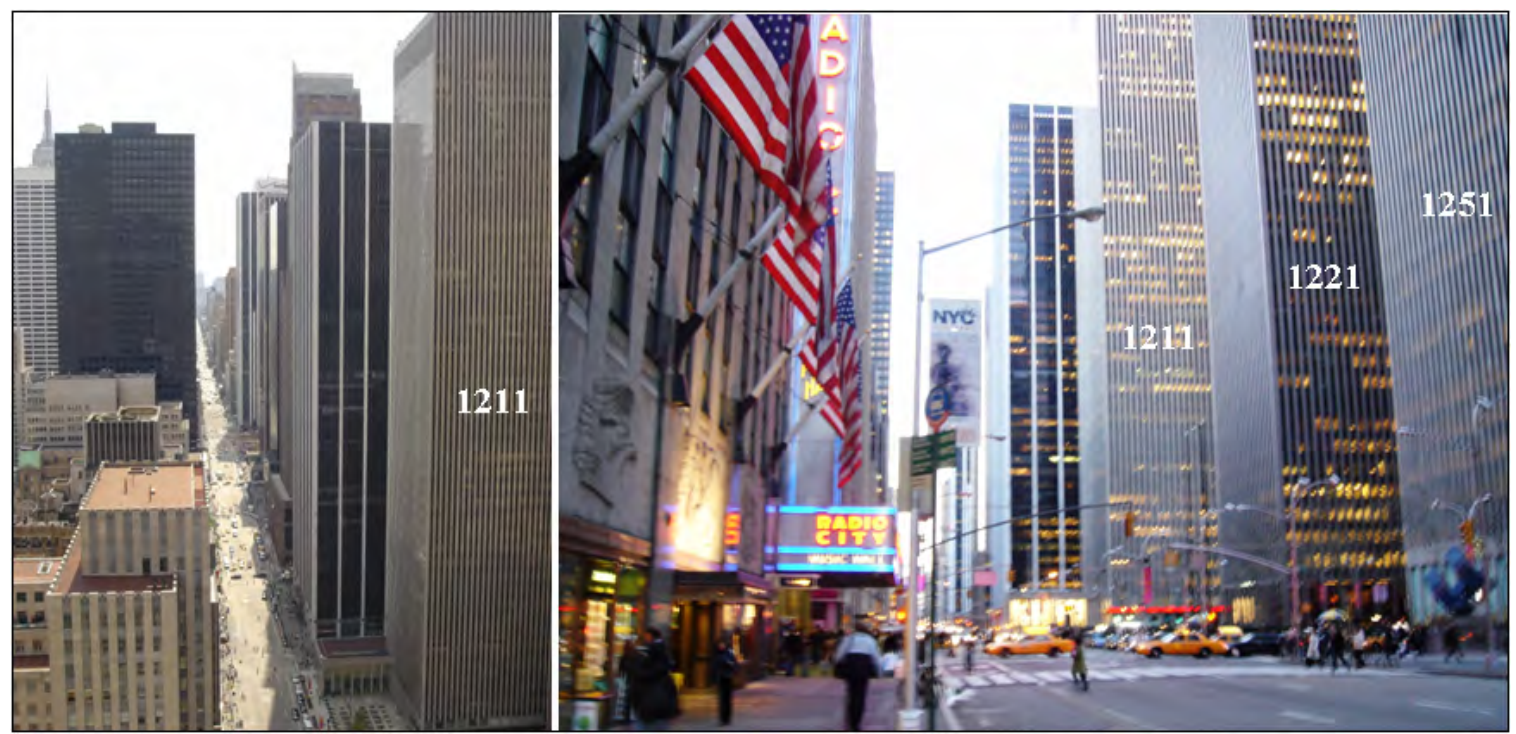

Figure 3.5. Avenue of the Americas ( $6^{\text {th }}$ Avenue) Looking South from Near $50^{\text {th }}$ Street and $6^{\text {th }}$ Avenue. The left panel is from the top of the Radio City Music Hall located on the northeast corner of $6^{\text {th }}$ Avenue and $50^{\text {th }}$ Street. The photograph in the right panel is from just north of Radio City Music Hall on the east side of $6^{\text {th }}$ Avenue. The numbers in the figure give the addresses of buildings (1211, 1221 and 1251 Avenue of the Americas) in the middle of the study domain. The CL release location is between buildings 1221 and 1251 on $49^{\text {th }}$ Street between $6^{\text {th }}$ and $7^{\text {th }}$ Avenues.

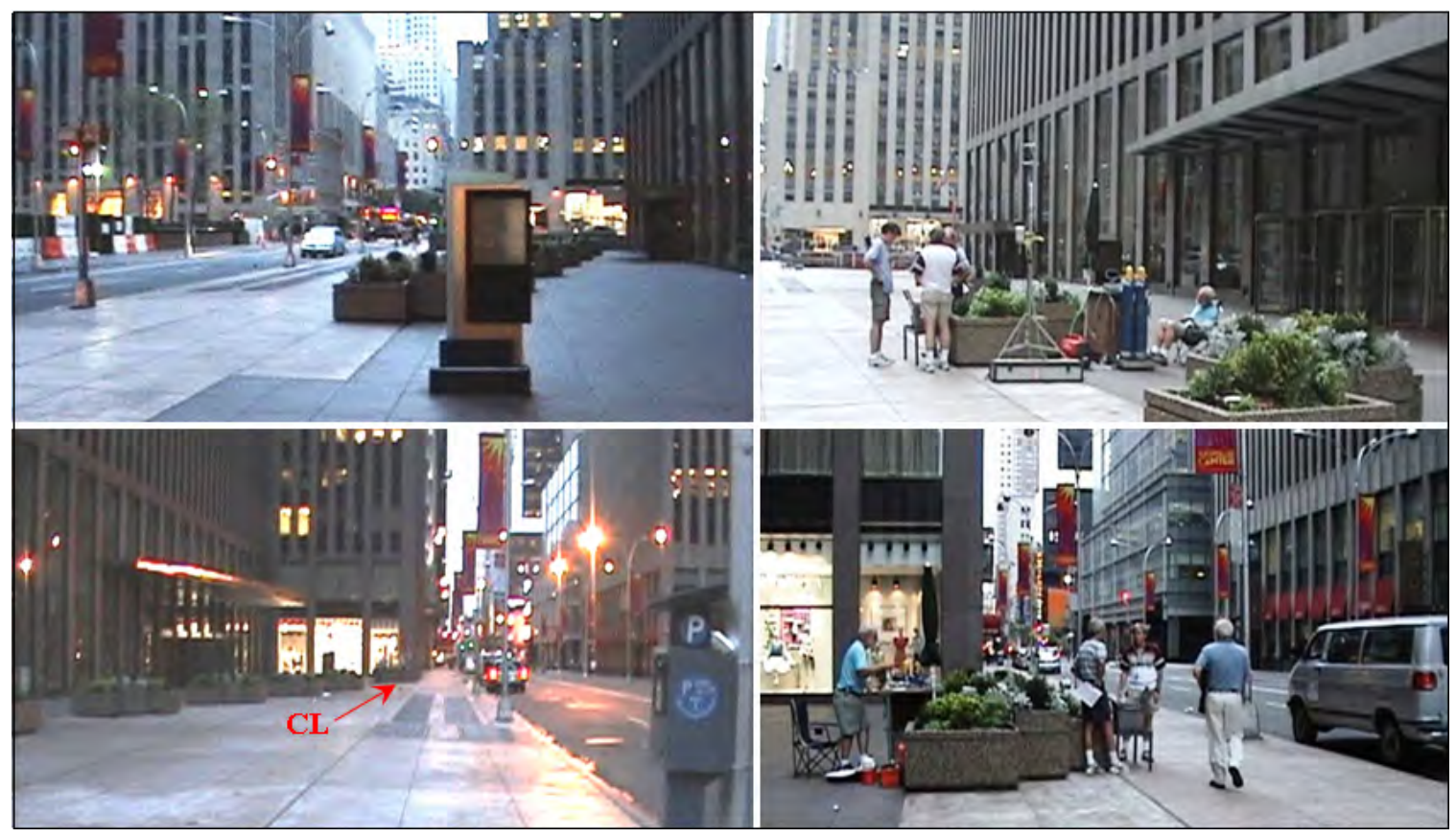

Figure 3.6. Photographs Looking West and East Along $49^{\text {th }}$ Street in the Vicinity of the CL Tracer Release Location. Upper panels are near CL looking east along $49^{\text {th }}$ Street and the lower panels are looking west. 


\subsection{Tracer Releases}

During an IOP six PFTs and $\mathrm{SF}_{6}$ were simultaneously released from a number of locations during three tracer release periods of 30-minutes each beginning at 6, 8 and 10 AM EST. Table 3.2 gives the names, formulae, molecular weights and background concentrations of the seven tracers used in MID05. The background concentration for each tracer is the average ambient tracer concentration measured by the background samplers for the six IOPs. The background samplers are those Midtown samplers well upwind of the tracer release locations and not influenced by the tracer released.

The tracer release rate for tracer experiments is primarily governed by the lower detection limit of the tracer sampling/analysis system and the maximum transport distance within the study domain. Because MID05 was a near-field experiment (within a 2-km-transport distance) and the lower detection limit for both PFTs and $\mathrm{SF}_{6}$ was near global background (PFTs - few parts per quadrillion, $\mathrm{SF}_{6}$ - few parts per trillion; see Table 3.2), small amounts of tracer were released resulting in 4-to-6 orders-of-magnitude dynamic range in measured concentrations within the study domain. The amount of each PFT released was $\sim 1$ to 1.5 milligrams s ${ }^{-1}$, and the amount of $\mathrm{SF}_{6}$ released was $\sim 3$ to 5 grams s $\mathrm{s}^{-1}$. The total amount of PFTs and $\mathrm{SF}_{6}$ released into the atmosphere for the MID05 study was approximately 270 grams PFT and 130 kilograms $\mathrm{SF}_{6}$; these amounts were negligible compared with other national sources. Figure 3.7 shows the PFT and $\mathrm{SF}_{6}$ release equipment deployed during MID05 with the capability to deliver the required release rates. The $\mathrm{SF}_{6}$ system consists of a cylinder of liquid $\mathrm{SF}_{6}$ providing gaseous $\mathrm{SF}_{6}$ through a mass flow controller where the tracer is released at the selected rate through a garden hose at $2 \mathrm{~m}$ above ground level (see Clawson et al. for details). ${ }^{\text {(a) }}$ The PFT system is based on a motor-driven syringe pump pushing liquid PFT onto a filter for rapid evaporation in a stream of air (see Watson et al. for details on the PFT release system). ${ }^{\text {(b) }}$ The complete system is battery-operated and is contained in a small, portable box placed on a table. The PFTs were released at a height of $\sim 1 \mathrm{~m}$ above ground level (AGL).

In addition to the outdoor dispersion component, the first three IOPs of MID05 involved an indoorstudy component where one modern office building in Midtown Manhattan (identified as "Building A" for privacy as requested by the building owner) was studied for flow characteristics and the exchange of tracers between the outdoors and the building. During these IOPs, three different perfluorocarbon tracers (PDCB, PMCH, and oc-PDCH) were released by LBNL in three air intakes of Building A to investigate the characteristics of the air-handling systems on indoor air movement. The indoor PFTs were released nearly instantaneously (few minutes duration) at the start of the first and third outdoor release periods (i.e., 0600 and 1000 EST). A release was not conducted during the second period to allow sufficient time for the tracer to "clear" from the building. Three additional PFTs (PMCP, i-PPCH, and PTCH) were released for 30-minutes each by BNL at three unique outdoor locations to observe the outdoor dispersion of tracers from different locations under the same meteorological conditions. The seventh and final tracer, sulfur hexafluoride, was released by the NOAA's FRD and was co-located with one of the PFT release positions for quality-assurance.

(a) KL Clawson, RG Carter, DJ Lacroix, JD Rich, D Finn, NF Hukari, and T Strong. 2007. "Midtown Manhattan 2005 (MID05) SF 6 Atmospheric Tracer Field Tests.” NOAA Technical Memorandum OAR ARL-258, Air Resources Laboratory Field Research Division. Idaho Falls, ID. [Limited Distribution - "Official Use Only"]

(b) TB Watson TB, J Heiser, P Kalb, RN Dietz, R Wilke, and J Adams. 2007. The New York City Urban Dispersion Program August 2005 Field Study: Tracer Methods and Results. BNL-77986-2007, Brookhaven National Laboratory, Upton, NY. [Limited Distribution - "Official Use Only"] 
Table 3.2. Acronyms, Chemical Names, Chemical Formulae, Molecular Weights and Background Concentrations of Perfluorocarbon Tracers and Sulfur Hexafluoride Tracer Used in the MID05 Study

\begin{tabular}{|c|c|c|c|c|}
\hline Acronym & Chemical Name & Formula & $\begin{array}{l}\text { Mol. Weight } \\
\left(\mathrm{g} \mathrm{mol}^{-1}\right)\end{array}$ & $\begin{array}{c}\text { Background Conc. } \\
(\text { ppq) })^{(a)}\end{array}$ \\
\hline PDCB & Perfluorodimethylcyclobutane & $\mathrm{C}_{6} \mathrm{~F}_{12}$ & 300 & 3 \\
\hline PMCP & Perfluoromethylcyclopentane & $\mathrm{C}_{6} \mathrm{~F}_{12}$ & 300 & 8 \\
\hline $\mathrm{PMCH}$ & Perfluoromethylcyclohexane & $\mathrm{C}_{7} \mathrm{~F}_{14}$ & 350 & 8 \\
\hline oc-PDCH & Perfluoro-1,2-dimethylcyclohexane & $\mathrm{C}_{8} \mathrm{~F}_{16}$ & 400 & 1 \\
\hline i-PPCH & Perfluoroisopropylcyclohexane & $\mathrm{C}_{9} \mathrm{~F}_{18}$ & 450 & 1 \\
\hline PTCH & Perfluorotrimethylcyclohexane & $\mathrm{C}_{9} \mathrm{~F}_{18}$ & 450 & 2 \\
\hline $\mathrm{SF}_{6}$ & Sulfur hexafluoride & $\mathrm{SF}_{6}$ & 146 & 7 (ppt) \\
\hline \multicolumn{5}{|c|}{$\begin{array}{l}\text { (a) PFT background concentrations in parts per quadrillion (1 part tracer in } 10^{15} \text { parts air); } \mathrm{SF}_{6} \\
\text { background concentrations in parts per trillion ( } 1 \text { part tracer in } 10^{12} \text { parts air). Background } \\
\text { concentration for each tracer is the average from all background samplers in Midtown during the six } \\
\text { IOPs. }\end{array}$} \\
\hline
\end{tabular}

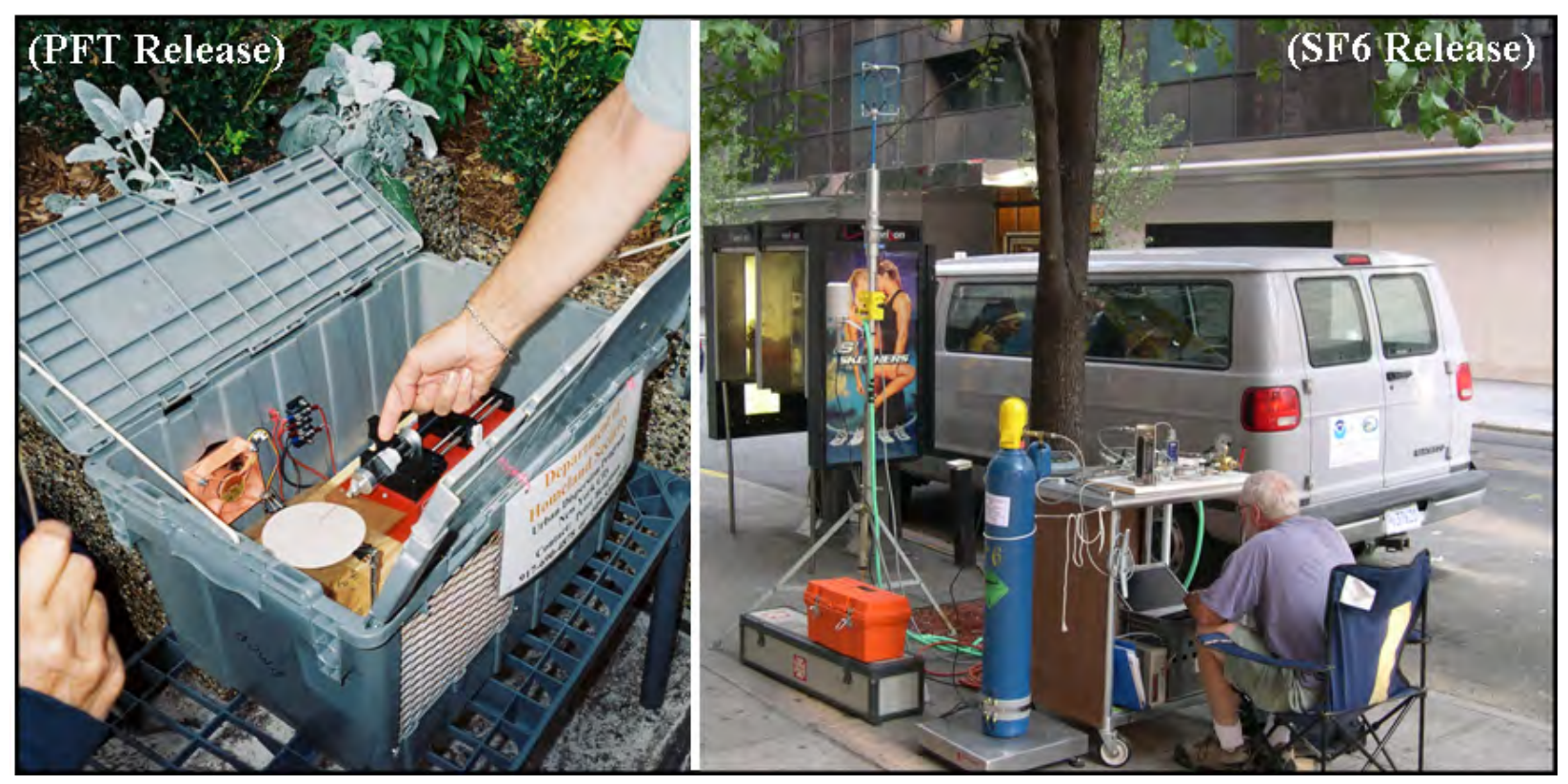

Figure 3.7. Pictures of PFT and $\mathrm{SF}_{6}$ Tracer Release Equipment as Deployed During MID05. The release heights were $1 \mathrm{~m}$ AGL for PFT and $2 \mathrm{~m}$ AGL for $\mathrm{SF}_{6}$.

The $\mathrm{SF}_{6}$ concentrations were measured within the Midtown study domain and within Building $\mathrm{A}$. The $\mathrm{SF}_{6}$ was used to measure the infiltration rate of an outdoor-released gas into a modern office building. Therefore, the $\mathrm{SF}_{6}$ was only released during the first and third release periods to allow extra time between releases for the $\mathrm{SF}_{6}$ to clear the building and clear Midtown before the next tracer release.

The final three IOPs of MID05 did not involve indoor tracer releases. As a result, the three PFTs that were used indoors during IOPs 1 through 3 were available to be released from other Midtown locations. Two of these PFTs were released at outdoor locations (one at a new location, and one co-located with 
another PFT for quality-assurance), while the third PFT was released in the subway. The three PFTs that were released indoors by LBNL during IOPs 1 through 3 were also released outdoors by BNL during IOPs 4 through 6. Just as the indoor release periods were designed to allow for extra ventilation time, the subway releases were also designed with this in mind. During the fourth and fifth IOPs, the subway tracer was released from the "uptown" (northbound) side of the subway station $\left(50^{\text {th }}\right.$ St. station on the 1,2,3 line) during the first and third release periods, while during the sixth IOP, only one subway tracer release was made during the first release period from the "downtown" (southbound) side of the station. Refer to Figure 3.2 for the two subway release locations ("Subway Uptown"—SU and "Subway Downtown"-SD) on a map of Midtown. Figure 3.8 shows the two subway release locations on a map of the $50^{\text {th }}$ St. subway station at $50^{\text {th }}$ St. and Broadway.

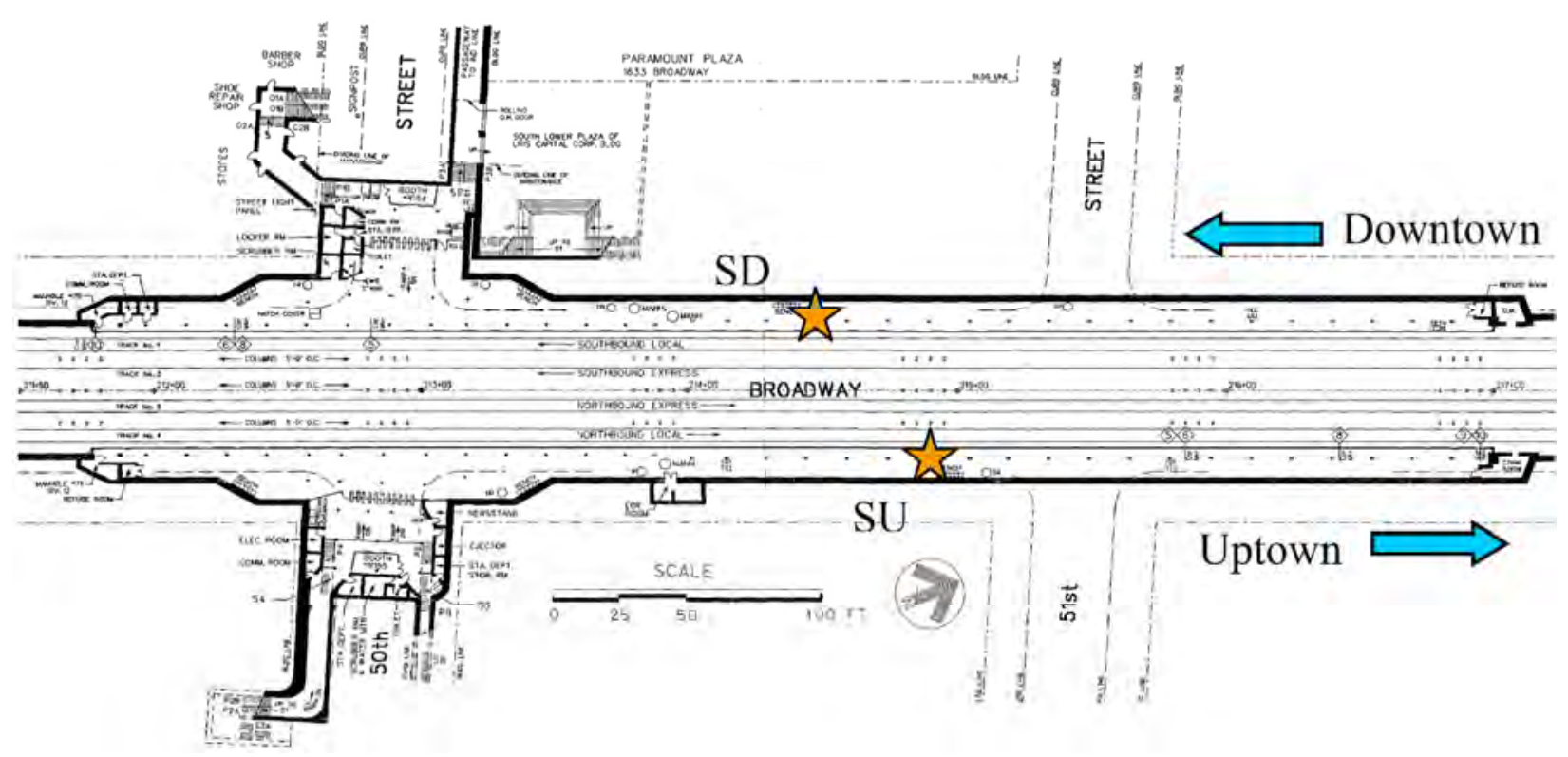

Figure 3.8. Release Locations Within the $50^{\text {th }}$ Street Subway Station on the $1,2,3$ Line.

The tracer release locations for each IOP depended on the experimental objective of the specific IOP. Two outdoor release locations designated as "Center Left” (CL) and "Center Right” (CR) were used during all six IOPs. Additionally, during the first three IOPs, the third outdoor release location was selected such that the $\mathrm{SF}_{6}$ tracer engulfed the indoor-study building to investigate the infiltration rate of tracer into a modern office building. Three release locations ("Southwest" - SW, "Southeast" - SE and "East-northeast"-ENE) were used, depending on the wind direction during the respective release period. The PFT and $\mathrm{SF}_{6}$ tracer release teams were unable to co-locate during the first release period of IOP 1 . Therefore, the PFT tracer team was positioned at SW-1 for the first release and moved to SW for subsequent releases. During the final three IOPs, two additional outdoor release locations were identified as "South" (S) and "Northeast" (NE) to investigate outdoor dispersion characteristics at different locations in Midtown. Figure 3.2 shows the locations of all the tracer releases. The coordinates of each release location are given in Appendix B. Table 3.3 and Table 3.4 summarize the tracer releases during each of the six IOPs. 
Table 3.3. Descriptions of MID05 Outdoor and Subway Tracer

Release Locations and Names of Tracers Released

\begin{tabular}{|l|l|l|l||}
\hline $\begin{array}{c}\text { Rel. } \\
\text { ID }\end{array}$ & \multicolumn{1}{|c|}{ Location Description } & $\begin{array}{c}\text { Tracers } \\
\text { (IOPs 1-3) }\end{array}$ & \multicolumn{1}{c|}{$\begin{array}{c}\text { Tracers } \\
\text { (IOPs 4-6) }\end{array}$} \\
\hline SW & South side of $44^{\text {th }}$ Street west of $7^{\text {th }}$ Avenue & i-PPCH, SF 6 & \\
\hline SW-1 & South side $44^{\text {th }}$ Street west of $7^{\text {th }}$ Avenue $($ east of SW) & i-PPCH & \\
\hline S & South side of $45^{\text {th }}$ Street between $6^{\text {th }}$ and $7^{\text {th }}$ Avenues & & i-PPCH \\
\hline SE & South side of $47^{\text {th }}$ Street west of $5^{\text {th }}$ Avenue & i-PPCH, SF & \\
\hline CL & South side of $49^{\text {th }}$ Street west of $6^{\text {th }}$ Avenue & PMCP & PMCP, SF \\
\hline CR & East side of $6^{\text {th }}$ Avenue between $49^{\text {th }}$ and $50^{\text {th }}$ Streets & PTCH & PTCH, oc-PDCH \\
\hline NE & North side of $54^{\text {th }}$ Street between $6^{\text {th }}$ \& $7^{\text {th }}$ Avenues & & PDCB \\
\hline ENE & South side of $53^{\text {rd }}$ Street between $5^{\text {th }}$ and $6^{\text {th }}$ Avenues & i-PPCH, SF 6 & \\
\hline SU & Uptown side of $50^{\text {th }}$ Street subway station on $1,2,3$ line & & PMCH \\
\hline SD & Downtown side of $50^{\text {th }}$ Street subway station on $1,2,3$ line & & PMCH \\
\hline
\end{tabular}

\subsection{Tracer Sampling}

Five different types of tracer samplers and two different types of real-time tracer analyzers were deployed during MID05 by various laboratories. This section details the deployment of the tracer samplers and analyzers.

\subsubsection{Integrating Tracer Samplers}

A key element of conducting a successful tracer field study is having a sufficient number of tracer samplers to provide the spatial and temporal resolution of measurements desired. Conducting tracer studies in urban areas requires a significant labor effort and funding, so it is generally cost effective to deploy as many tracer samplers as practical. Typically, a single organization or laboratory does not maintain a sufficient number of tracer samplers for a major study, so it is necessary to pool resources from several organizations. This approach was adopted for MID05 where five different samplers were supplied and operated by three different laboratories. An additional design element of MID05 was to use both PFTs and $\mathrm{SF}_{6}$ to accomplish the goals of the study. $\mathrm{SF}_{6}$ was used because of the dependability and precision of the sampling and analysis method, the ability to measure concentrations in near real-time, and the ability to release a small amount and still have a significant plume signal within the UDP study domain. PFTs were used because of the ability to release small amounts of up to six different PFTs simultaneously, collect all PFTs using common samplers, and analyze the samples using common analytical systems.

Different types of tracer samplers are needed for $\mathrm{SF}_{6}$ and PFTs. $\mathrm{SF}_{6}$ samplers collect whole-air samples, and PFT samplers concentrate the PFTs onto adsorbent tubes by drawing the ambient air through adsorbent tubes at a specified flow rate and for a specified amount of time. A total of 158 tracer samplers were deployed during MID05 where 80 (40 SF 6 and 40 PFT) were deployed by FRD, 42 ( $\mathrm{SF}_{6}$ ) by LLNL, and 36 (PFT) by BNL for a total of $82 \mathrm{SF}_{6}$ and 76 PFT samplers. 
Table 3.4. Summary of MID05 Tracer Releases

\begin{tabular}{|c|c|c|c|c|c|c|c|}
\hline IOP & Date & DOY $^{(\mathbf{a})}$ & $\begin{array}{l}\text { Release Time } \\
\text { (EST) }\end{array}$ & $\begin{array}{c}\text { Outdoor PFT } \\
\text { Releases }\end{array}$ & $\begin{array}{c}\mathrm{SF}_{6} \\
\text { Releases }\end{array}$ & $\begin{array}{l}\text { Indoor } \\
\text { PFTs }^{(b)}\end{array}$ & $\begin{array}{l}\text { Subway } \\
\text { PFTs }\end{array}$ \\
\hline 1 & $8 / 8 / 05$ & 220 & $\begin{array}{l}0600-0630 \\
0800-0830 \\
1000-1030\end{array}$ & $\begin{array}{c}\text { SW-1, CL, CR } \\
\text { SW, CL, CR } \\
\text { SW, CL, CR }\end{array}$ & $\begin{array}{c}\text { SW } \\
- \\
\text { SW }\end{array}$ & $\begin{array}{l}3 \\
- \\
3\end{array}$ & $\begin{array}{l}- \\
- \\
-\end{array}$ \\
\hline 2 & $8 / 12 / 05$ & 224 & $\begin{array}{l}0600-0630 \\
0800-0830 \\
1000-1030\end{array}$ & $\begin{array}{c}\text { ENE, CL, CR } \\
\text { SE, CL, CR } \\
\text { SE, CL, CR }\end{array}$ & $\begin{array}{c}\text { ENE } \\
- \\
\text { SE }\end{array}$ & $\begin{array}{l}3 \\
- \\
3\end{array}$ & $\begin{array}{l}- \\
- \\
-\end{array}$ \\
\hline 3 & $8 / 14 / 05$ & 226 & $\begin{array}{l}0600-0630 \\
0800-0830 \\
1000-1030 \\
\end{array}$ & $\begin{array}{l}\text { SW, CL, CR } \\
\text { SW, CL, CR } \\
\text { SW, CL, CR }\end{array}$ & $\begin{array}{c}\text { SW } \\
- \\
\text { SW } \\
\end{array}$ & $\begin{array}{l}3 \\
- \\
3 \\
\end{array}$ & $\begin{array}{l}- \\
- \\
-\end{array}$ \\
\hline 4 & $8 / 18 / 05$ & 230 & $\begin{array}{l}0600-0630 \\
0800-0830 \\
1000-1030\end{array}$ & $\begin{array}{l}\text { S, NE, CL, CR, CR } \\
\text { S, NE, CL, CR, CR } \\
\text { S, NE, CL, CR, CR }\end{array}$ & $\begin{array}{l}\mathrm{CL} \\
\mathrm{CL} \\
\mathrm{CL}\end{array}$ & $\begin{array}{l}- \\
- \\
-\end{array}$ & $\begin{array}{c}\text { SU } \\
- \\
\text { SU }\end{array}$ \\
\hline 5 & $8 / 20 / 05$ & 232 & $\begin{array}{l}0600-0630 \\
0800-0830 \\
1000-1030 \\
\end{array}$ & $\begin{array}{l}\text { S, NE, CL, CR, CR } \\
\text { S, NE, CL, CR, CR } \\
\text { S, NE, CL, CR, CR }\end{array}$ & $\begin{array}{l}\mathrm{CL} \\
\mathrm{CL} \\
\mathrm{CL}\end{array}$ & $\begin{array}{l}- \\
- \\
-\end{array}$ & $\begin{array}{c}\text { SU } \\
- \\
\text { SU } \\
\end{array}$ \\
\hline 6 & $8 / 24$ & 236 & $\begin{array}{l}0600-0630 \\
0800-0830 \\
1000-1030\end{array}$ & $\begin{array}{l}\text { S, NE, CL, CR, CR } \\
\text { S, NE, CL, CR, CR } \\
\text { S, NE, CL, CR, CR }\end{array}$ & $\begin{array}{l}\mathrm{CL} \\
\mathrm{CL} \\
\mathrm{CL}\end{array}$ & $\begin{array}{l}- \\
- \\
-\end{array}$ & $\begin{array}{c}\text { SD } \\
- \\
-\end{array}$ \\
\hline \multicolumn{8}{|c|}{$\begin{array}{l}\text { (a) DOY is the day of year (DOY = } 1 \text { is January 1). } \\
\text { (b) Number of PFTs released indoors as near-instantaneous releases (few minutes) at the start of the respective } \\
\text { release period. }\end{array}$} \\
\hline
\end{tabular}

FRD deployed 40 programmable integrating gas samplers (PIGS) for collecting whole-air samples for $\mathrm{SF}_{6}$ analysis. These samplers have been used successfully in past field campaigns such as Urban 2000 and Joint Urban 2003. The PIGS samplers sequentially collected air samples in 12 Tedlar ${ }^{\circledR}$ bags that were subsequently analyzed for $\mathrm{SF}_{6}$ in the laboratory by FRD using gas chromatography with an electron capture detector (GC-ECD). FRD also deployed 40 PIGS samplers that were modified to contain 12 capillary adsorption tube samplers (CATS) instead of 12 bags for collecting samples for PFT analysis. The CATS, supplied by and analyzed by BNL, are composed of glass tubes packed with Ambersorb ${ }^{\circledR}$ adsorbent. Air was pumped through the tubes for 30 minutes, and the mass of tracer material deposited onto the adsorbent was analyzed in the laboratory by BNL using GC-ECD upon desorption of the sample. A PFT (pt-PDCH) that was not released, but was assumed to be at a constant and known concentration in the atmosphere, was used to compute the volume of air that was passed through the tube. The mass of the tracer of interest and the air volume computed from the reference tracer (pt-PDCH) were used together to compute the concentration. The two sets of PIGS units deployed by FRD during MID05 are identified as PIGS-SF $_{6}$ and PIGS-PFT and are shown in Figure 3.9.

BNL deployed two types of samplers for measuring PFTs as shown in Figure 3.10. Seven sequential air samplers (SASs) and 29 Brookhaven atmospheric tracer samplers (BATS) were deployed. The SAS units sequentially collected samples on CATS tubes contained within a 20-position cartridge that automatically sequenced based on the sampling program. The BATS collected PFT material on an adsorbent where the adsorbent was packed in stainless steel tubes (rather than a glass tube as for SAS 
units) enclosed in a permanent lid (shown in Figure 3.10). The volume of air sampled by a BATS adsorbent tube ( $~ 1.5$ liters) was larger than through a PIGS-PFT CATS ( $~ 0.8$ liters), but smaller than through a SAS CATS ( 15 liters) for the 30-minute sampling times. The BNL samplers are identified as SAS-PFT and BATS-PFT for completeness.
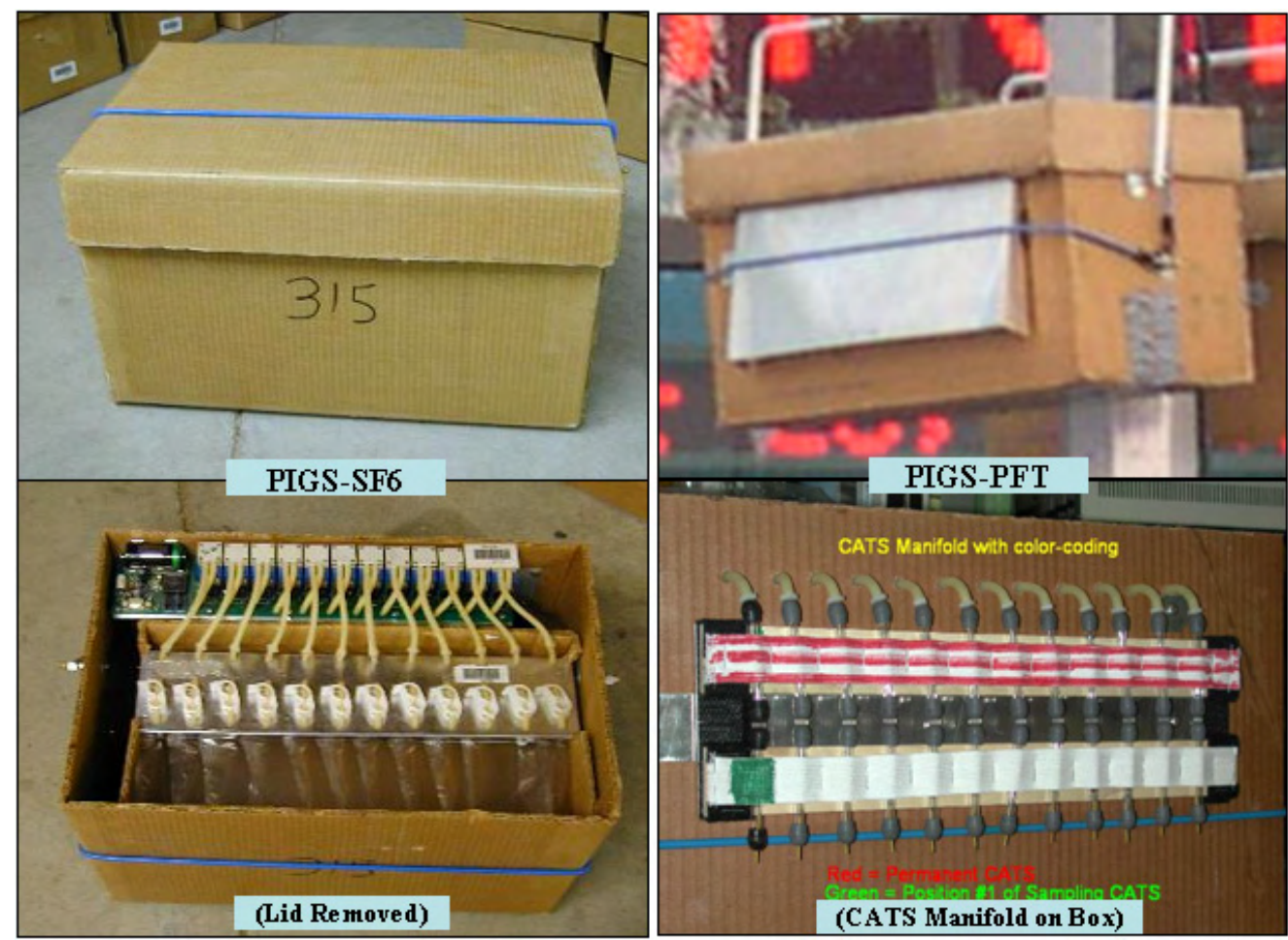

Figure 3.9. FRD 12-Position PIGS Sampler Collecting Air Samples into Bags (left side) and Adapted to Collecting Air Samples into Adsorption Tubes (right side)

LLNL deployed 42 "BlueBox" samplers for collecting $\mathrm{SF}_{6}$ samples $\left(\mathrm{BB}-\mathrm{SF} \mathrm{F}_{6}\right)$. These samplers nominally collected 5-minute samples of $\mathrm{SF}_{6}$ tracer, where each sampler has 15 sampling bags that can be programmed with various sample-integration times as desired.

During the MID05 field campaign, additional tracer samplers (over the 158 discussed above) were deployed by each laboratory as part of their respective quality assurance programs. Typically, an additional $10 \%$ of samplers are deployed as duplicates, blanks, and/or controls. BNL deployed three BATS as duplicates at street-level and one SAS as a roof-top duplicate. The quality assurance procedure followed by FRD is described by Clawson et al. ${ }^{(a)}$ The locations of the tracer samplers used for quality control are not given in this report.

(a) KL Clawson, RG Carter, DJ Lacroix, JD Rich, D Finn, NF Hukari, and T Strong. 2007. "Midtown Manhattan 2005 (MID05) $\mathrm{SF}_{6}$ Atmospheric Tracer Field Tests.” NOAA Technical Memorandum OAR ARL-258, Air Resources Laboratory Field Research Division. Idaho Falls, ID. [Limited Distribution - "Official Use Only”] 


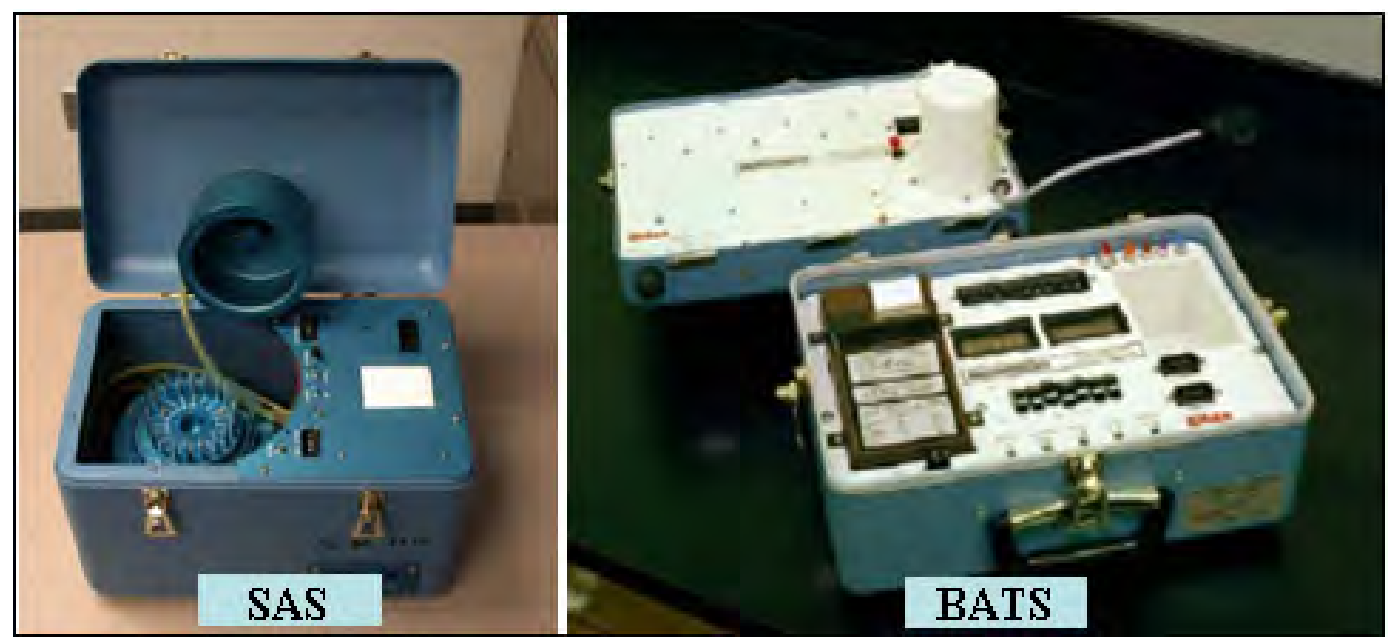

Figure 3.10. BNL 20-Position SAS Sampler (left side) for Collecting Samples into CATS Tubes and a BNL 22-Position BATS Sampler (right side) for Collecting Samples onto Permanent Adsorption Tubes Contained in the Sampler lid

Table 3.5 summarizes the distribution of the 158 tracer samplers among sampling locations at streetlevel, on building tops, and within the subway. Because of the different experimental objectives accomplished during the first three IOPs versus the last three, the samplers were distributed slightly differently when the indoor-component of the study was underway (IOPs 1 to 3). Also given in Table 3.5 are the sampling times for the various tracer samplers. The sampling times for some samplers were slightly different between IOPs 1 to 3 versus IOPs 4 to 6 .

Figure 3.11 through Figure 3.14 show the locations of all the street-level, roof-top, and subway tracer samplers deployed within the Midtown study area during MID05. Appendix B gives the street locations and coordinates of all the sampler locations. Figure 3.11 shows the locations of the 21 BATS-PFT samplers, the 40 PIGS-PFT samplers, and the 36 PIGS-SF $_{6}$ samplers deployed on light poles during all IOPs. The 6-by-6 inner grid of sampling points contained 36 PIGS-PFT and 36 PIGS-SF 6 samplers collocated on light poles at $\sim 3.5 \mathrm{~m}$ AGL. The 21 BATS-PFT samplers and the remaining 4 PIGS-PFT samplers were deployed around the perimeter of the 6-by-6 grid as shown in Figure 3.11. The perimeter BATS-PFT samplers were located on light poles at $~ 3 \mathrm{~m}$ AGL and the 4 perimeter PIGS-PFT samplers at $3.5 \mathrm{~m}$ AGL. Note that sampling positions 4, 8 and 61 were not used during MID05 because of final revisions to the deployment of available samplers. Also note in Figure 3.11 that two positions are identified for each of locations 28 and 37. Positions 28b and 37b were the desired positions at light poles, but because of permission delays, samplers were not placed on the light poles during the first IOPs. Instead, they were placed at ground-level (sample inlets less than $1 \mathrm{~m}$ AGL) with field staff at nearby locations, denoted as 28a and 37a. The sampler at 28a was placed on the pole at 28b during IOPs 3 to 6 , and the sampler at 37a was placed on the light pole at 37b during IOPs 4 to 6 . 
Table 3.5. Number of Integrating Tracer Samplers, Averaging Time (AVE) in Minutes and Sampling Period (EST). "STR" refers to street-level, "RF” to roof-top, and "SUB” to subway samplers.

\begin{tabular}{|c|c|c|c|c|c|c|c|c|c|c|}
\hline \multirow{2}{*}{$\begin{array}{c}\text { SAMPLER } \\
\text { TYPE }\end{array}$} & \multicolumn{5}{|c|}{ IOPs 1-3 } & \multicolumn{5}{|c|}{ IOPs 4-6 } \\
\hline & STR & RF & SUB & AVE & PERIOD & STR & RF & SUB & AVE & PERIOD \\
\hline BATS-PFT & 21 & & 8 & 30 & $0600-1200$ & 21 & & 8 & 30 & 0600-1200 \\
\hline SAS-PFT & & 5 & & 30 & $0600-1200$ & & 7 & & 30 & 0600-1200 \\
\hline PIGS-PFT & 40 & & & 30 & $0600-1200$ & 40 & & & 30 & $0600-1200$ \\
\hline${\mathrm{PIGS}-\mathrm{SF}_{6}}$ & 36 & 4 & & 30 & $\begin{array}{l}0530-0830 \\
0930-1230\end{array}$ & 36 & 4 & & 30 & 0600-1200 \\
\hline $\mathrm{BB}_{-} \mathrm{SF}_{6}{ }^{(\mathrm{a})}$ & & 4 & & 10 & $\begin{array}{l}0600-0700 \\
1000-1100\end{array}$ & 38 & 4 & & 5 & $\begin{array}{l}0600-0650 \\
0800-0850 \\
1000-1050 \\
\end{array}$ \\
\hline TOTAL & 97 & 13 & 8 & & & 135 & 15 & 8 & & \\
\hline
\end{tabular}

(a) The four roof-top samplers during IOPs 1 to 3 were actually revised samplers (denoted as "Gray Boxes") that contained 12 sampling bags each rather than 15 as with the standard BBs. During IOPs 4 to 6, two conventional BBs were deployed at each of 19 street-level locations and 2 roof-top locations. Two BBs were needed at each sampling location to provide a total of 30 sampling bags ( 15 per sampler) to cover the sampling periods with 5-minute-average samples.

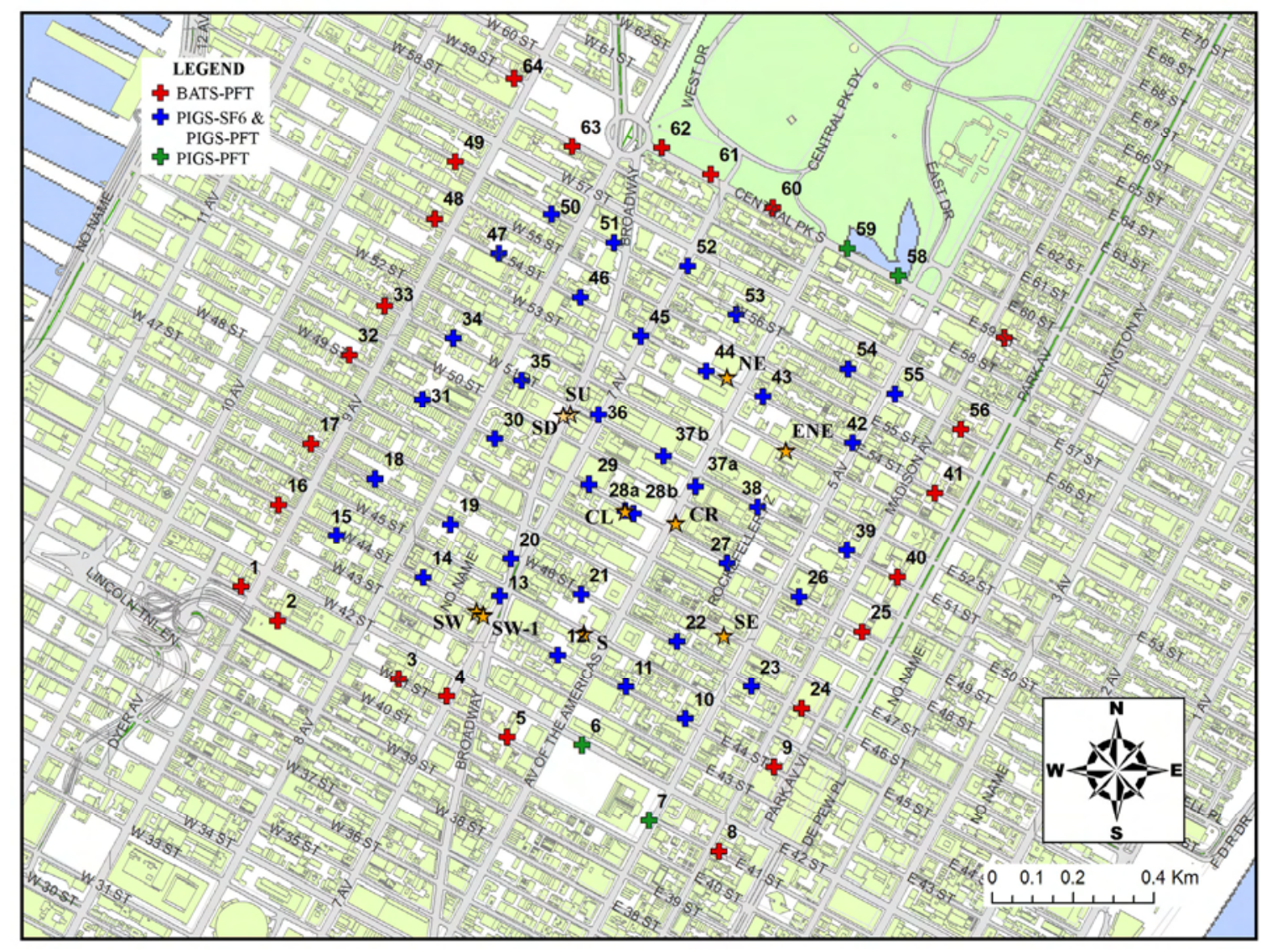

Figure 3.11. Locations of Street-Level Integrating Tracer Samplers Within the MID05 Study Domain. (Positions 4, 8, and 61 were never used.) 
As shown in Table 3.5, 13 tracer samplers were placed on roof-tops during IOPs 1 to 3 and 15 were placed during IOPs 4 to 6 . Figure 3.12 shows the locations of the roof-top samplers within the MID05 study domain. Not all roof-top locations were used during each IOP. Table 3.6 summarizes the roof-top sampling for all IOPs. Eight BATS-PFT samplers were placed in various subway stations to observe dispersion in and through the subway system. Figure 3.13 gives the locations of the subway samplers.

Figure 3.14 shows the 21 locations for the street-level BB-SF 6 samplers deployed during IOPS 4 to 6 . During each IOP, 38 samplers were placed at 19 locations. Two samplers were placed at each location, providing 30 sampling bags (15 bags per sampler) to cover the three 50 -minute sampling periods with 5-minute-average samples. During IOPs 4 and 5, samplers were not placed at locations G19 and G20, and during IOP 6, samplers were not placed at locations G1 and G6.

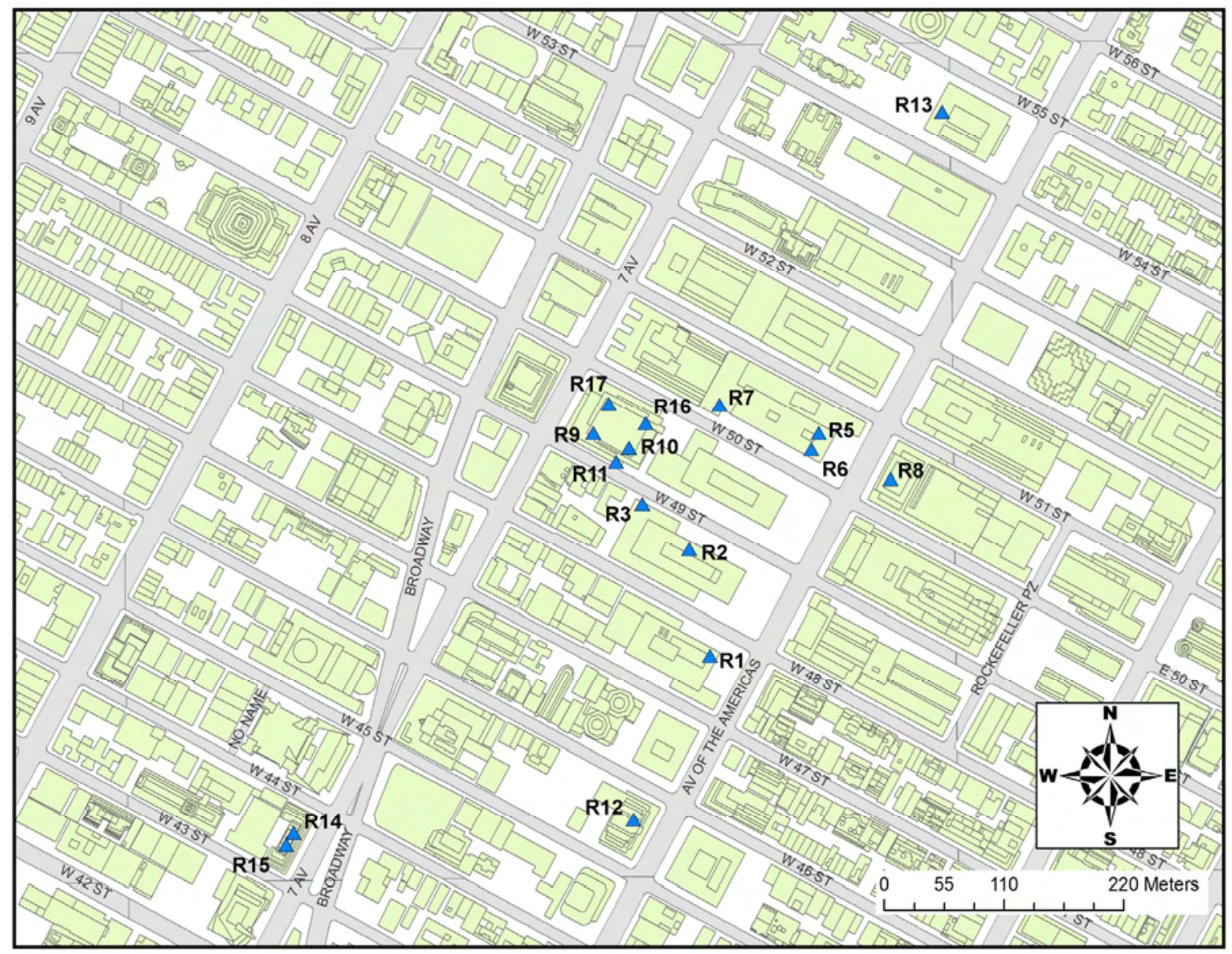

Figure 3.12. Rooftop Integrating Tracer Sampler Locations Within the MID05 Study Domain 
Table 3.6. Deployment of Roof-Top Tracer Samplers for each IOP by Sampler Type Where "S" Denotes an SAS-PFT Sampler (five or seven units), "B" a BB-SF 6 Sampler (four units) and "Px" a PIGS-SF 6 Sampler (four units). Note that the number accompanying the "P" identifies the FRD sampler number as 500x. For example, P4 refers to FRD sampler number 5004.

\begin{tabular}{|c|c|c|c|c|c|c|}
\hline \multirow{2}{*}{$\begin{array}{c}\text { LOCATION } \\
\text { ID }\end{array}$} & \multicolumn{6}{|c|}{ IOP NUMBER } \\
\hline & 1 & 2 & 3 & 4 & 5 & 6 \\
\hline R01 & $\mathrm{S}$ & & & P4 & P4 & $\mathrm{P} 4$ \\
\hline R02 & $S$ & S, P1 & S, P1 & S, P1 & S, P1 & S, P1 \\
\hline R03 & $S$ & $\mathrm{~S}$ & $S$ & $S$ & $\mathrm{~S}$ & $S$ \\
\hline R05 & $S$ & S, P2 & S, P2 & $\mathrm{S}, \mathrm{P} 2$ & S, P2 & $\mathrm{S}, \mathrm{P} 2$ \\
\hline R06 & & & $\mathrm{S}$ & & & \\
\hline R07 & $S$ & $S$ & & & & \\
\hline R08 & & $\mathrm{S}$ & $\mathrm{S}$ & S, P3 & S, P3 & S, P3 \\
\hline R09 & $\mathrm{B}, \mathrm{P} 2$ & $\mathrm{~B}, \mathrm{P} 3$ & $\mathrm{~B}$ & & & \\
\hline R10 & B,P1 & $\mathrm{B}, \mathrm{P} 4$ & $\mathrm{~B}, \mathrm{P} 4$ & S, B,B & S, B, B & S, B, B \\
\hline $\mathrm{R} 11$ & & & P3 & S, B,B & S, B, B & S, B, B \\
\hline $\mathrm{R} 12$ & & & & & $S$ & \\
\hline R13 & & & & $\mathrm{S}$ & & $\mathrm{S}$ \\
\hline $\mathrm{R} 14$ & P3 & & & & & \\
\hline $\mathrm{R} 15$ & $\mathrm{P} 4$ & & & & & \\
\hline R16 & $\mathrm{B}$ & B & $\mathrm{B}$ & & & \\
\hline $\mathrm{R} 17$ & $\mathrm{~B}$ & $\mathrm{~B}$ & $\mathrm{~B}$ & & & \\
\hline TOTAL & 13 & 13 & 13 & 15 & 15 & 15 \\
\hline
\end{tabular}

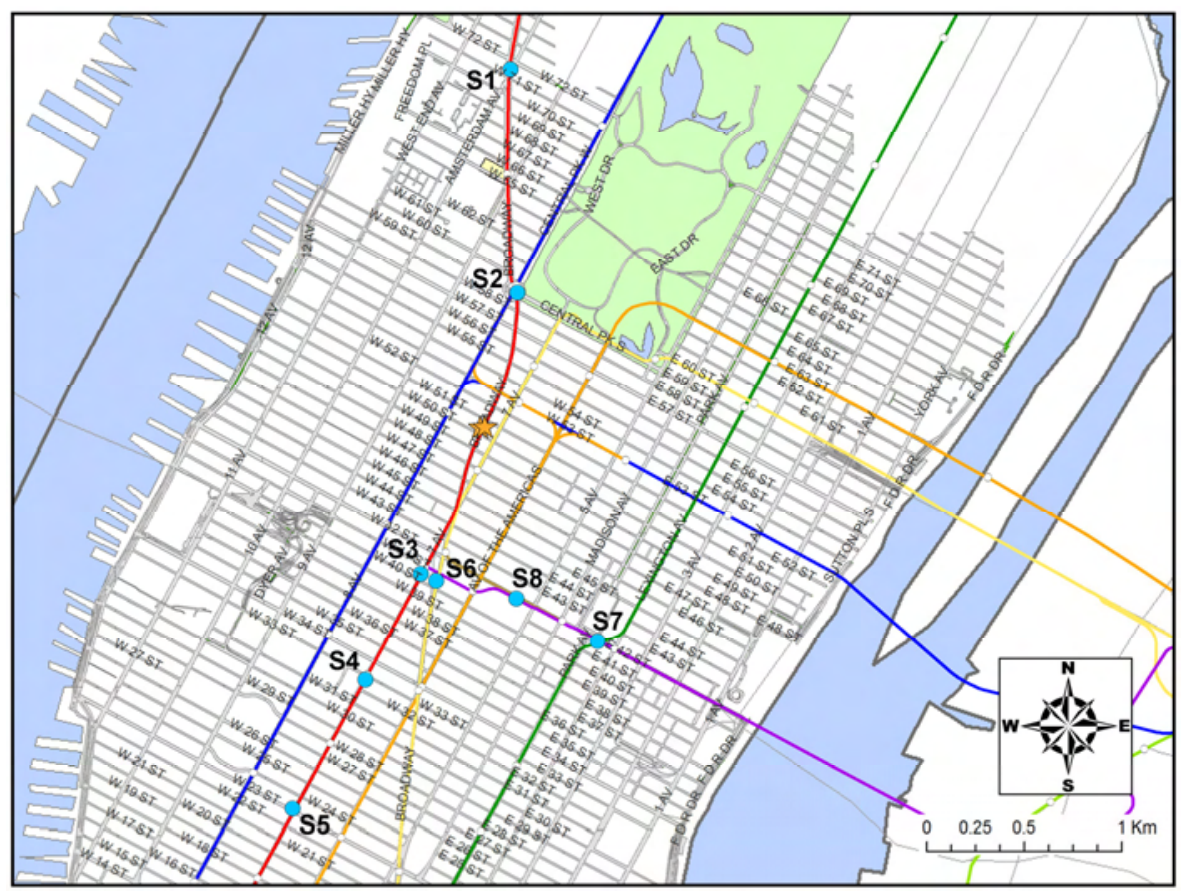

Figure 3.13. Subway Tracer Measurement Locations (blue dots) and Subway Releases (orange stars). Colored lines represent Midtown Manhattan subway lines. 


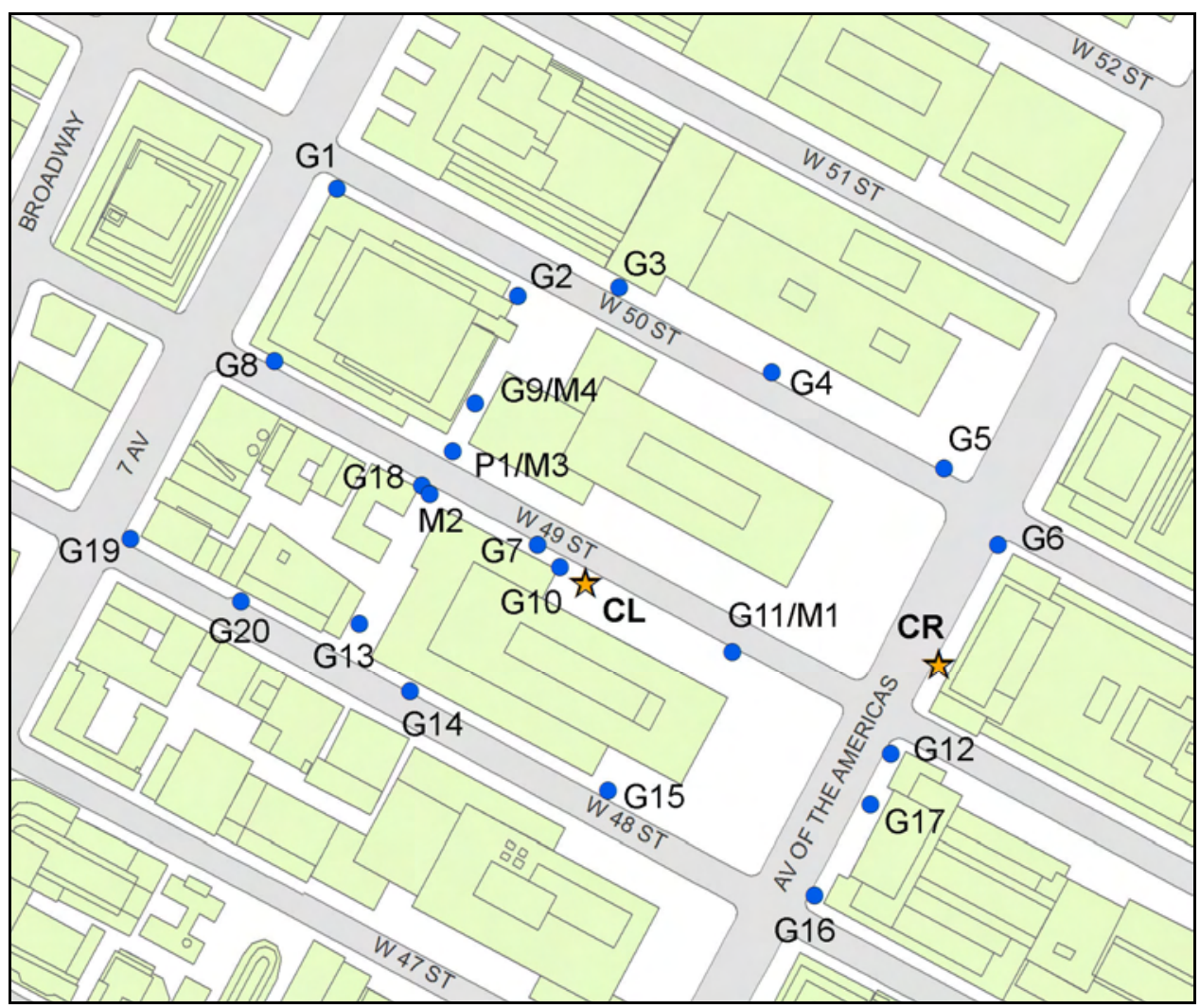

Figure 3.14. Locations of Street-Level BB-SF 6 Samplers Near the Center of the MID05 Study Domain. Also shown are the locations of the four real-time Miran $\mathrm{SF}_{6}$ analyzers. The street-level sampler locations are identified with a "G” or "P," and the Miran analyzer locations are identified with an "M."

\subsubsection{Fast-Response Tracer Sampling}

In addition to the integrating tracer samplers, fast-response tracer analyzers were deployed to help characterize the instantaneous behavior of the tracers. FRD deployed five vans with fast-response $\mathrm{SF}_{6}$ tracer analyzers (see Figure 3.15) called trace-gas analyzers (TGAs) with a sample inlet $~ 2 \mathrm{~m}$ AGL and a sampling rate of $2 \mathrm{~Hz}$. Four of these analyzers were deployed at fixed locations where they remained at the same location throughout a particular release period and subsequent measurement period. The fixed vans changed positions from one IOP to the next and sometimes changed positions from one release to the next during an IOP. One TGA was operated in a mobile mode and drove transects through the plume throughout the study period. During a particular IOP, the mobile TGA was generally downwind of the fixed van positions and drove along two streets or avenues near the downwind edge of the study domain. The positions of the fixed $\mathrm{SF}_{6}$ tracer analyzers for each IOP are shown in Figure 3.16, and coordinates are given in Appendix $\mathrm{B}$. Additional details about the $\mathrm{SF}_{6}$ tracer deployment, sampling, and analysis conducted by FRD can be found in Clawson et al. ${ }^{\text {(a) }}$ An additional four $\mathrm{SF}_{6}$ tracer analyzers, called Mirans, were deployed by LLNL in the near-field with the BB-SF 6 samplers.

(a) KL Clawson, RG Carter, DJ Lacroix, JD Rich, D Finn, NF Hukari, and T Strong. 2007. "Midtown Manhattan 2005 (MID05) SF 6 Atmospheric Tracer Field Tests.” NOAA Technical Memorandum OAR ARL-258, Air Resources Laboratory Field Research Division. Idaho Falls, ID. [Limited Distribution - "Official Use Only"] 

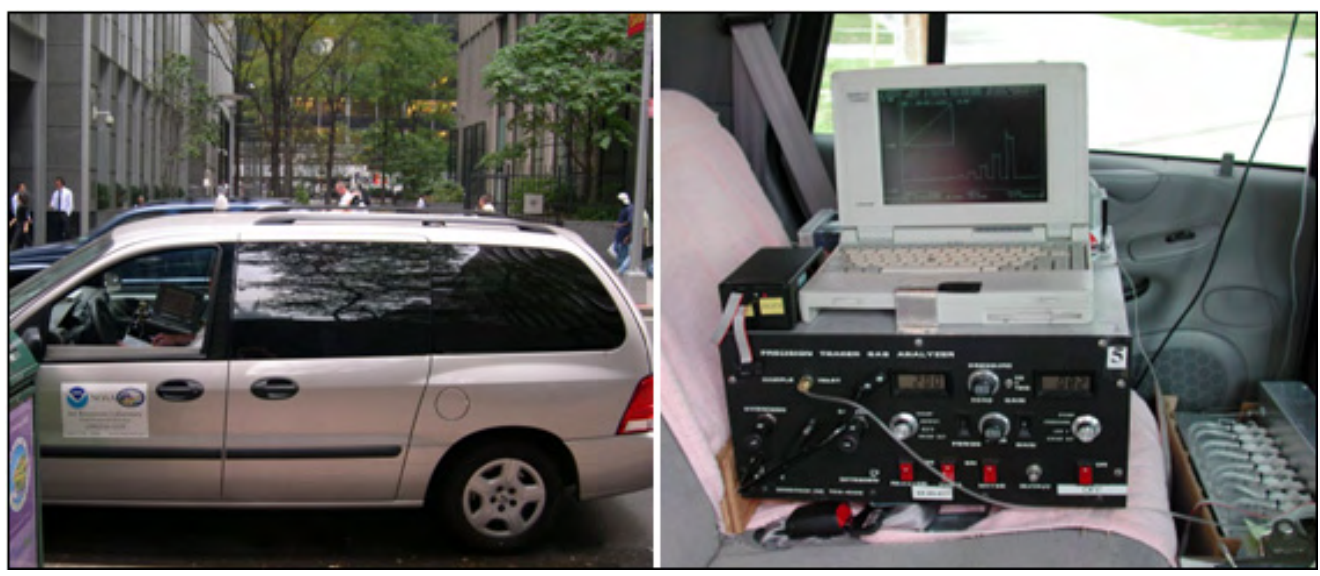

Figure 3.15. FRD Deployed Fast-Response $\mathrm{SF}_{6}$ Analyzer at Fixed Location in the Study Area Using Vans. The sample inlet line is 2-m AGL, and the instrument sampling rate is $2 \mathrm{~Hz}$.

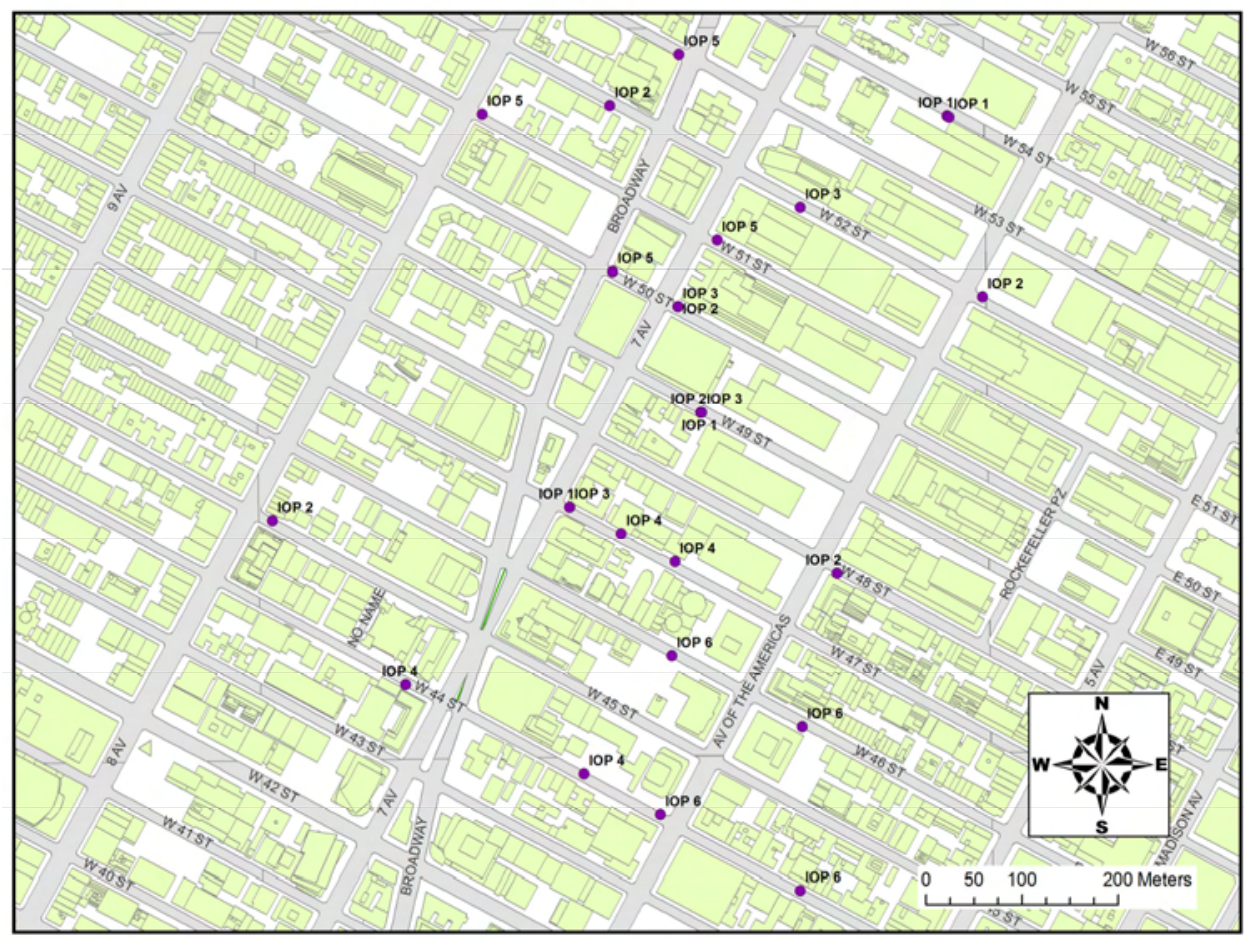

Figure 3.16. Fast-Response $\mathrm{SF}_{6}$ Analyzers at Fixed Locations Deployed by FRD

The positions of the Mirans are given in Figure 3.14, and the coordinates are given in Appendix B. The Mirans sampled air at 1-m AGL with a 1-Hz sampling rate.

Figure 3.17 shows pictures of the various deployment methods for the integrating tracer samplers and the Miran fast-response $\mathrm{SF}_{6}$ analyzer. The PIGS-PFT and PIGS-SF 6 samplers were hung at $~ 3.5 \mathrm{~m} \mathrm{AGL}$ from pre-installed brackets on light poles before each IOP and removed after each IOP. The BATS-PFT samplers were placed in pre-installed baskets located on light poles at $~ 3 \mathrm{~m} \mathrm{AGL}$ and were also placed and removed before and after each IOP. The BB-SF 6 samplers were placed at ground-level with the 
sampling inlet lines extending to $\sim 1 \mathrm{~m} \mathrm{AGL}$. The four Miran fast-response $\mathrm{SF}_{6}$ analyzers were placed on carts at the desired sampling locations and were monitored at all times. The Miran inlets were at 1-meter AGL.
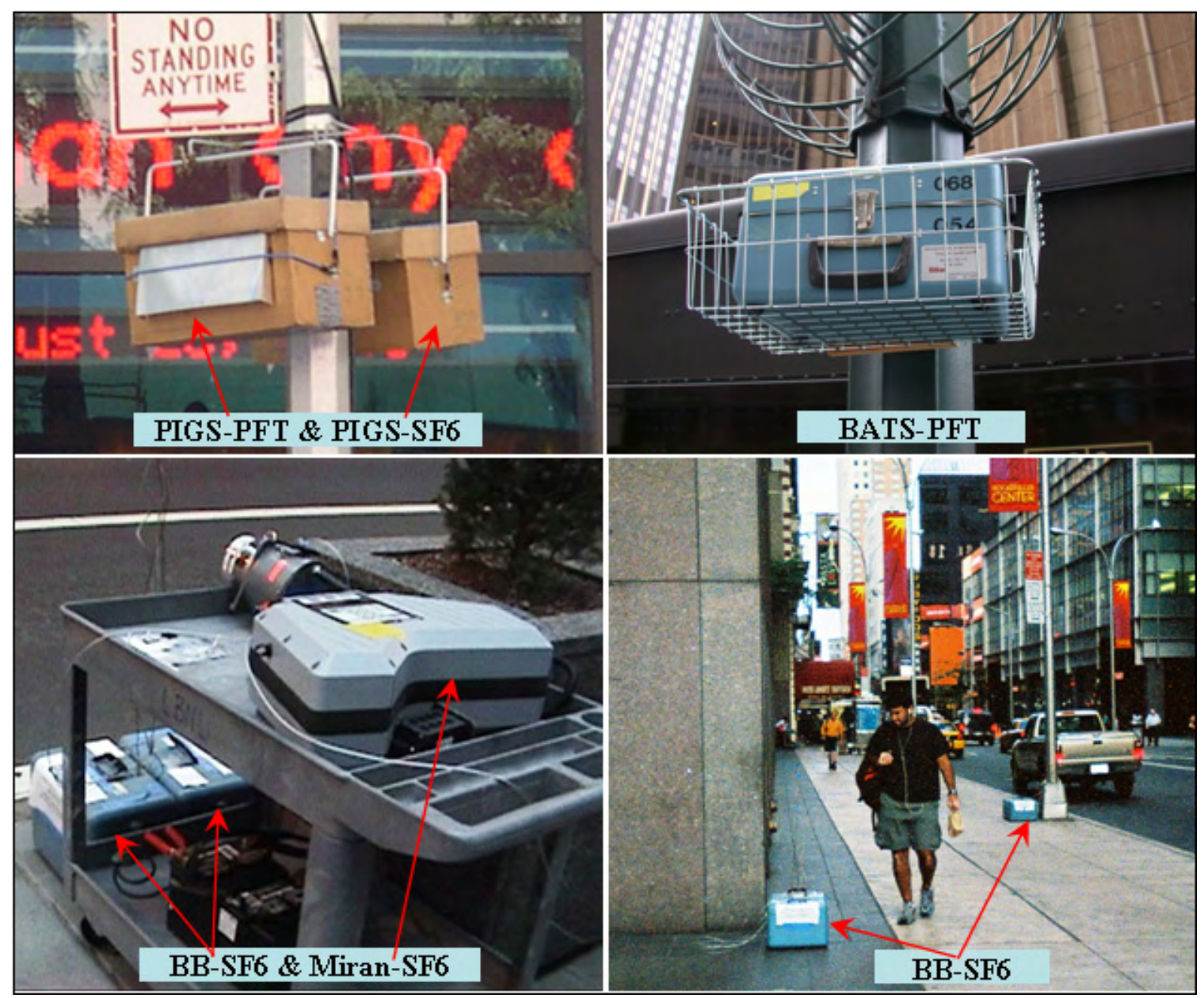

Figure 3.17. Tracer Samplers as Deployed During MID05. The PIGS samplers were deployed on wire hangers at 3.5-m AGL on light poles as shown in the upper-left panel, and the BATS units were deployed at 3-m AGL placed within baskets as shown in the upper-right panel. The BB samplers were deployed in pairs at ground-level with the sampling inlet $\sim 1$-m AGL as shown in the lower panels. Also shown in the lower-left panel is a Miran infrared analyzer for measuring $\mathrm{SF}_{6}$ in real-time at a $1-\mathrm{Hz}$ sampling rate.

\subsection{Meteorological Measurements}

The MID05 field experiment employed a number of meteorological instruments to characterize the winds in and around Midtown Manhattan. In the near field, five rooftop 3-D sonic anemometers were deployed on 6-meter tripods to help describe the flow just above the city. These were installed on the rooftops of One Penn Plaza, Park Plaza, the MetLife Building, the McGraw-Hill Building (1221 Avenue of the Americas), and the General Motors Building. The roofs of these buildings had numerous structures, including air-handling systems that presented potential local obstructions to the wind 
measurements. However, the sonics were deployed at locations on the building roofs with the least obstructions to flows from the prevailing wind directions (southeast through southwest). With the exception of periods of heat-related instrument failures, these roof-top sonics operated continuously throughout the field study. In addition to these five temporary roof-top stations, data from a permanent meteorological station operated by NOAA on the roof of the Lehman Brothers Building were collected.

To supplement the measurements from the rooftop sonics, two building setback 3-D sonics were installed partway up the sides of two buildings (1221 Avenue of the Americas and Lehman Brothers) to help describe flows through a particular street canyon ( $49^{\text {th }}$ Street between $6^{\text {th }}$ and $7^{\text {th }}$ Avenues). The two setback sonics were $\sim 2 \mathrm{~m}$ offset from the sides of the respective buildings at about 30 to $40 \mathrm{~m}$ above street level.

Ten street-level 3-D sonic anemometers were also deployed on 3-meter tripods during IOPs in the center of the measurement domain to give an indication of the channeling that occurs in the region near the centermost tracer-release positions. FRD also deployed a street-level 3-D sonic anemometer at the $\mathrm{SF}_{6}$ release position during each IOP. The final components of the near-field meteorological measurements were two rooftop-installed sodars. These two sodars, deployed on the rooftops of the MetLife and General Motors Buildings, characterize the vertical structure of the atmosphere from the tops of the building to approximately 200 meters above the instrument. Figure 3.18 shows pictures of some of the meteorological instruments as deployed during MID05.

Additional meteorological measurements were made outside the core-study domain. To the west of the domain across the Hudson River from Midtown at SIT, both a radar wind profiler (measures winds up to $\sim 2500$ meters above the instrument) and a radiosonde balloon-borne profiling system provided upperair meteorological measurements for the study. A permanent meteorological station located on the roof of the SIT Howe Building and operated by SIT provided an additional source of data. A permanent rooftop sonic anemometer operated by NOAA located on the roof of EML provided meteorological data near Downtown Manhattan, and data from a rooftop sonic anemometer at the Marshak Science building of the City College of New York provided meteorological data north of Central Park. Finally, ASOSs operated by NWS provided data on an hourly basis from nearby airports as well as from Central Park.

Figure 3.19 through Figure 3.22 show the positions of the meteorological instruments with maps zoomed in at different levels from the core study area out to the overall area of NYC. The labels in these figures correspond to the station names listed in the coordinate table in Appendix C. Note that these station names (in general) were prescribed for MID05, some names may not match the ASOS designation (such as CPK for Central Park instead of NYC), and other names may not point to a unique building name in NYC (such as MGH for the McGraw-Hill building, which is the name of a building at 1221 Ave of the Americas as well as at $220 \mathrm{~W} 42^{\text {nd }}$ Street). The maps and coordinates presented in this document are the definitive source of position information for the instruments used in this study. Also note that ASOS coordinates provided by the NWS have been refined based on aerial and Graphical Information System (GIS) maps. Additional information about the meteorological instruments and the quantities measured can be found in Reynolds et al. (2007). 


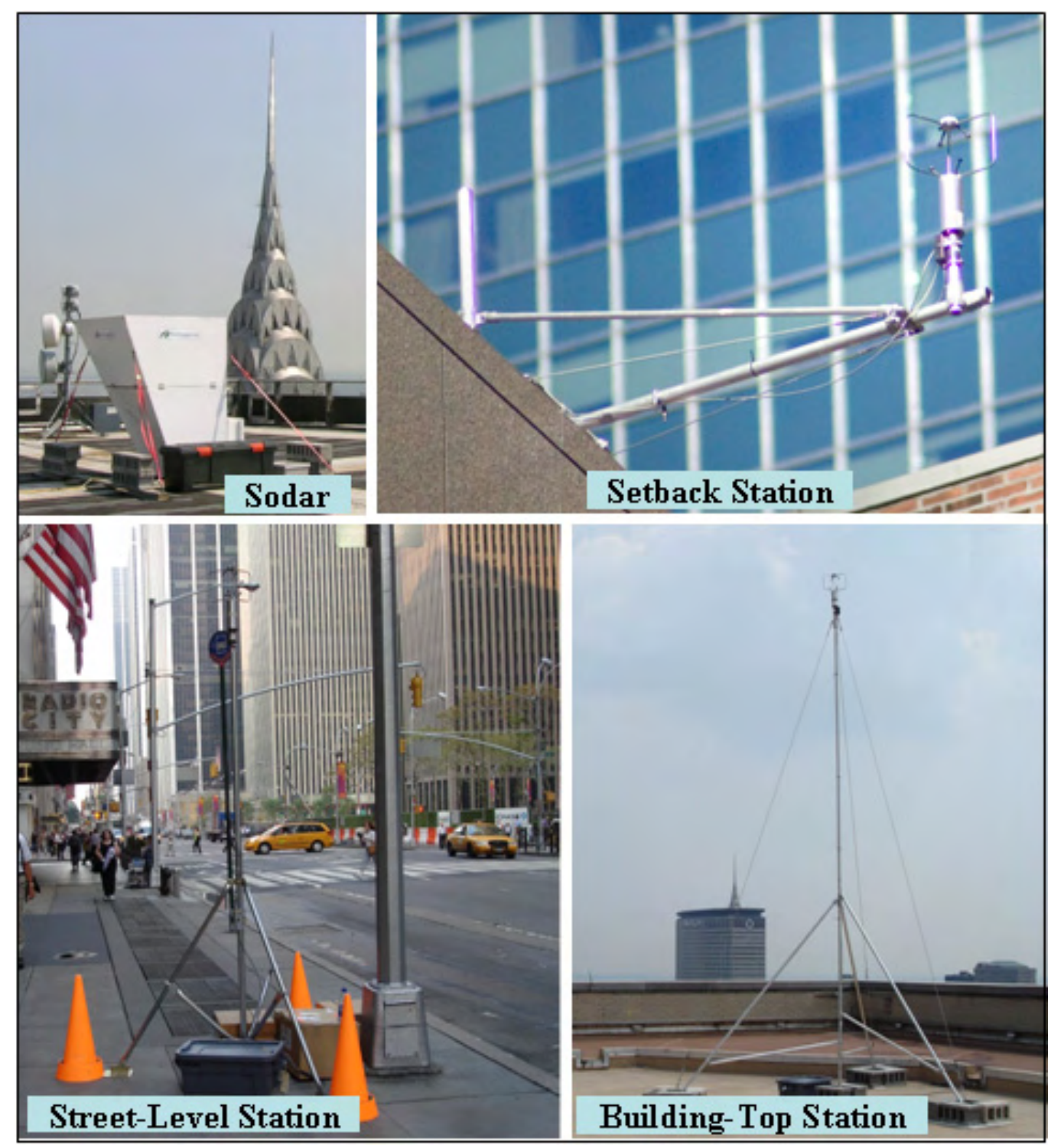

Figure 3.18. Meteorological Instruments Deployed During MID05 


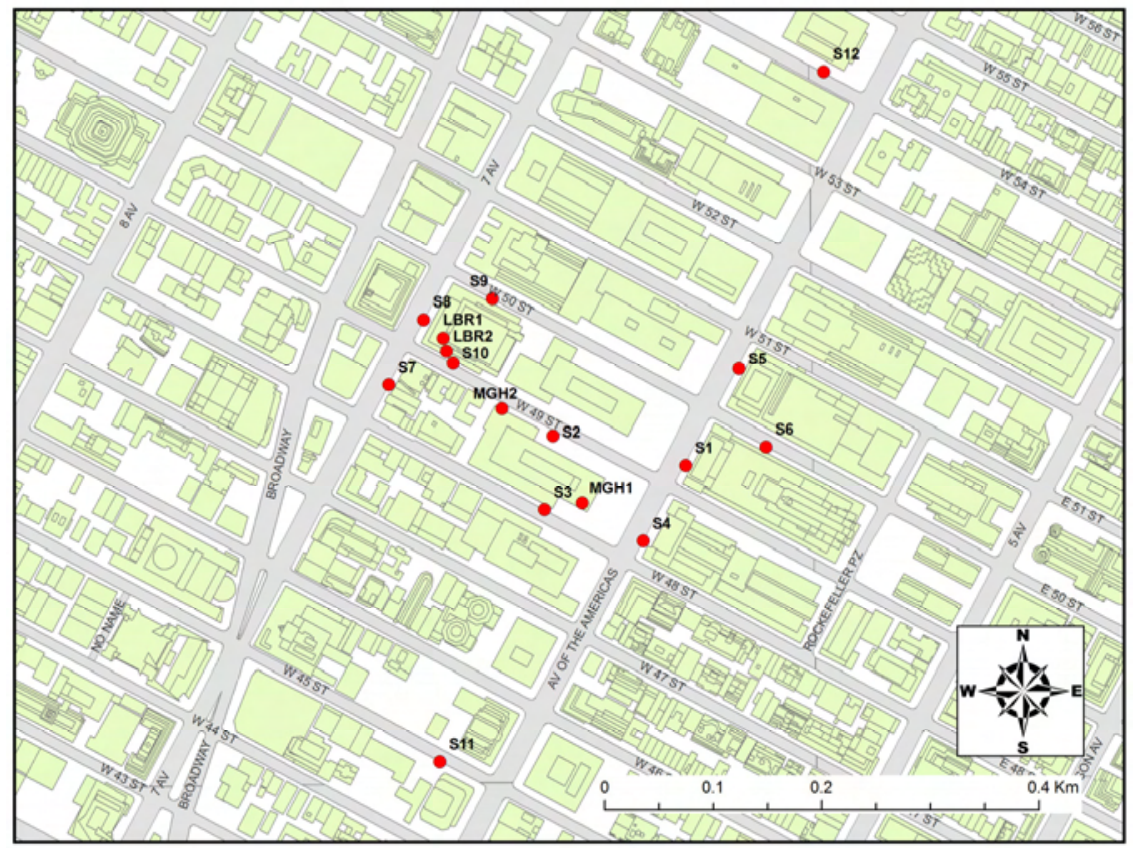

Figure 3.19. Locations of Sonic Anemometers in the MID05 Study Domain. MGH1 and LBR1 are roof-top stations, and MGH2 and LBR2 are offset stations. Locations S1 through S12 denote the locations of the 10 sonic-anemometer stations deployed at street-level during each IOP.

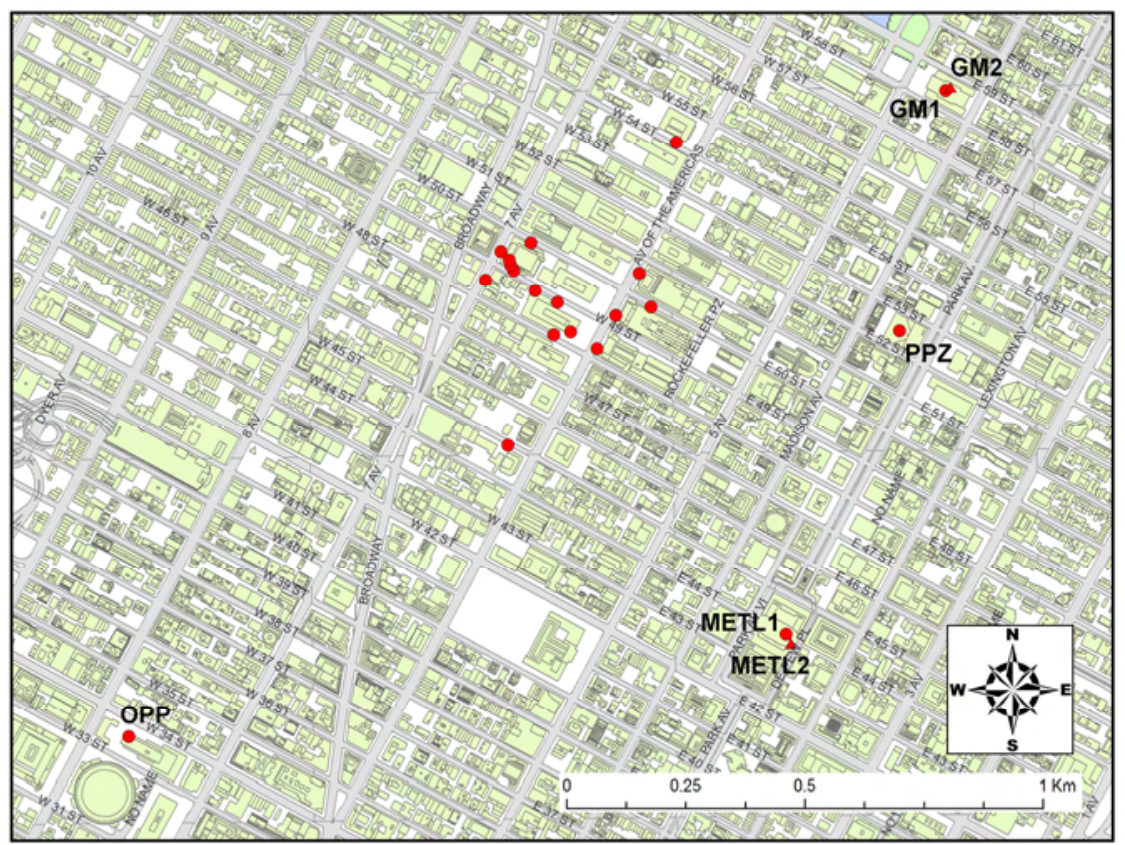

Figure 3.20. Locations of Four Roof-Top Meteorological Stations (OPP, METL1, PPZ and GM1) and Two Roof-Top Sodars (METL2 and GM2) in the MID05 Study Domain. Also shown are the sonic locations given in Figure 3.19. 


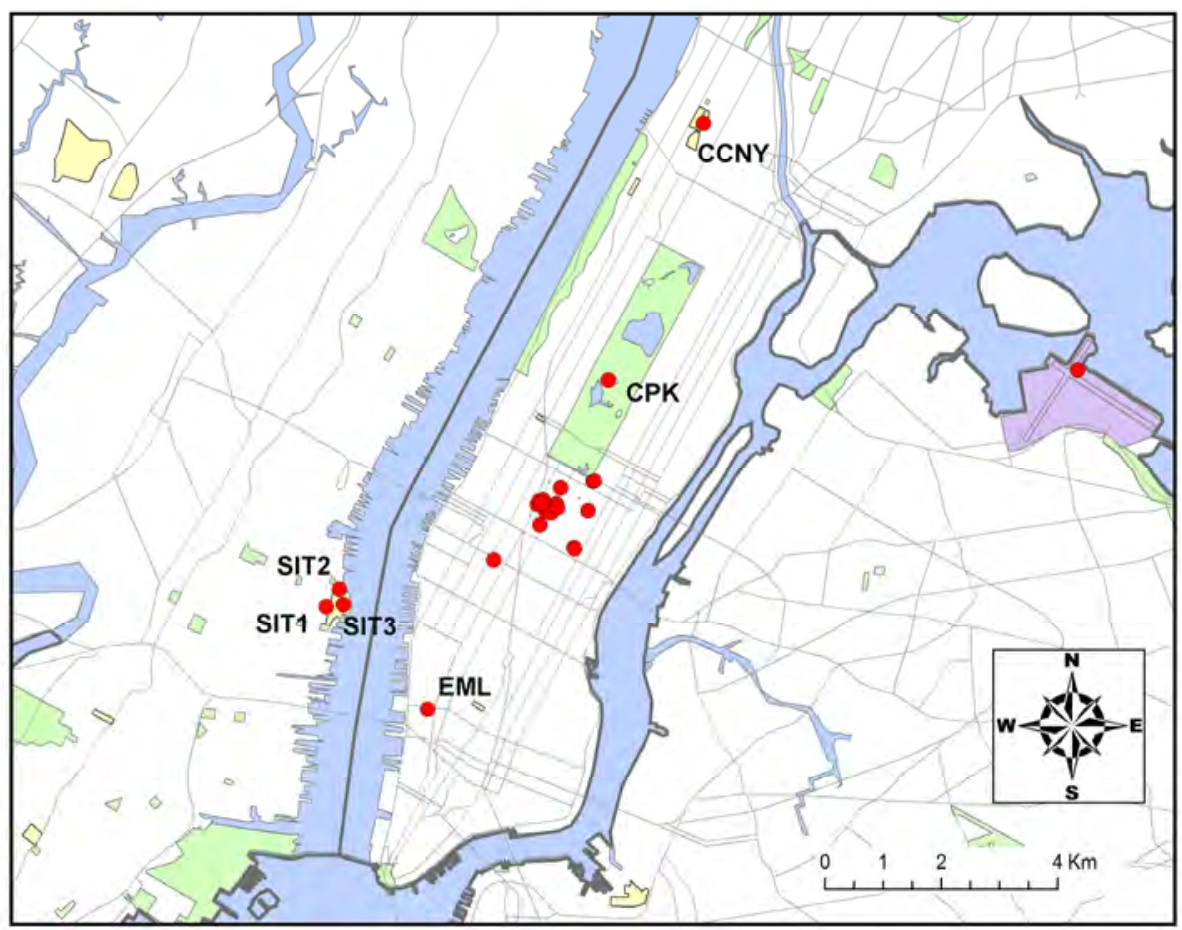

Figure 3.21. Locations of Existing Meteorological Stations (SIT3, EML, CPK and CCNY) in the NYC Area. Also shown are the locations of the radiosonde system (SIT1) and the radar wind profiler (SIT2) deployed as part of MID05.

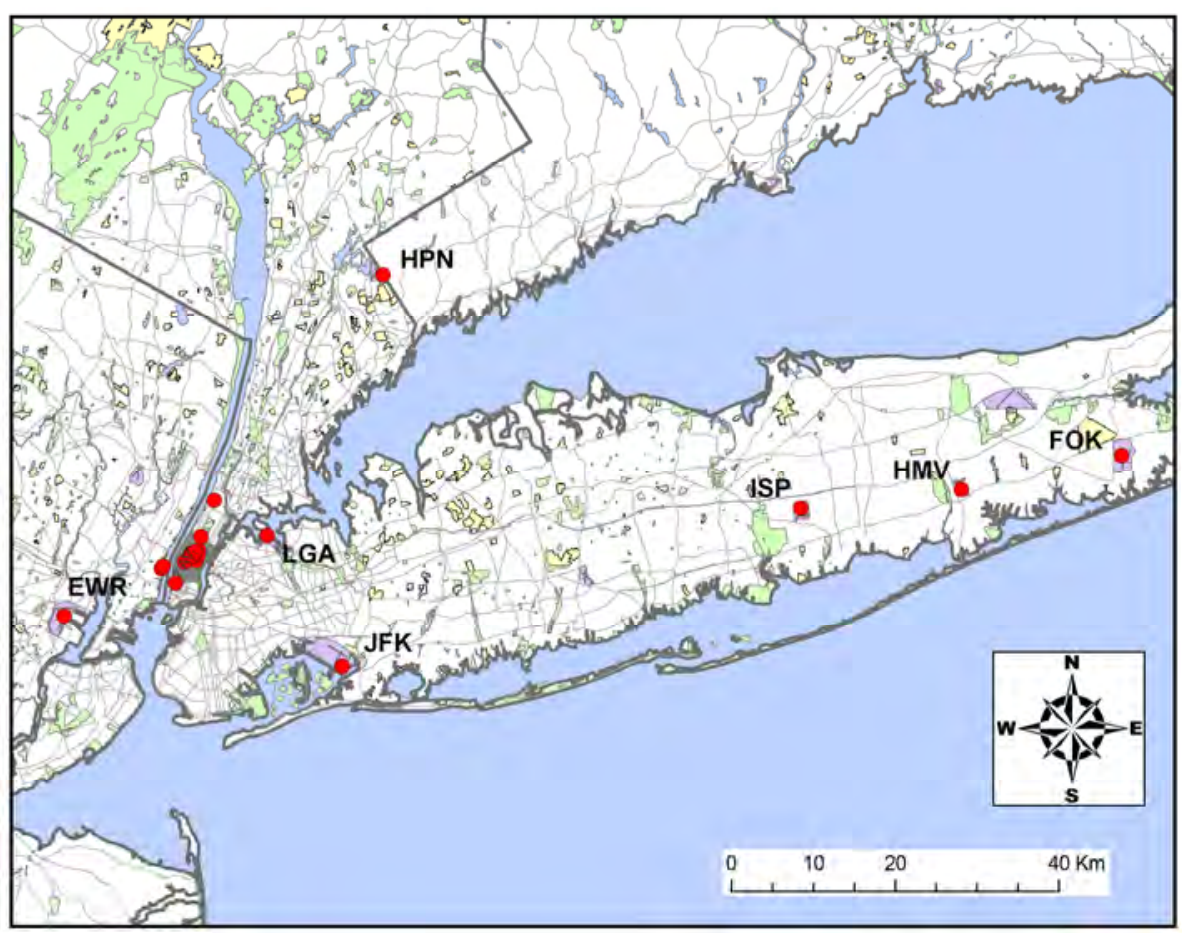

Figure 3.22. Locations of National Weather Service Stations in the Greater NYC Region 
Seventeen air-temperature sensors called HOBOs ${ }^{\circledR}$ from Onset Computer Corporation were mounted on light poles at $\sim 3 \mathrm{~m}$ AGL. Two perpendicular transects passed through the center of the MID05 study domain. Nine HOBOs ${ }^{\circledR}$ extended across Manhattan from the Hudson River to the East River and 8 HOBOs ${ }^{\circledR}$ extended along the center of Midtown Manhattan from near $28^{\text {th }}$ Street in the south to approximately $70^{\text {th }}$ to the north (in Central Park). Due to logistical constraints, the HOBOs ${ }^{\circledR}$ collected data only from August 17 through August 26, 2005. The locations of the HOBOs ${ }^{\circledR}$ are shown in Figure 3.23, and the coordinates are listed in Appendix C.

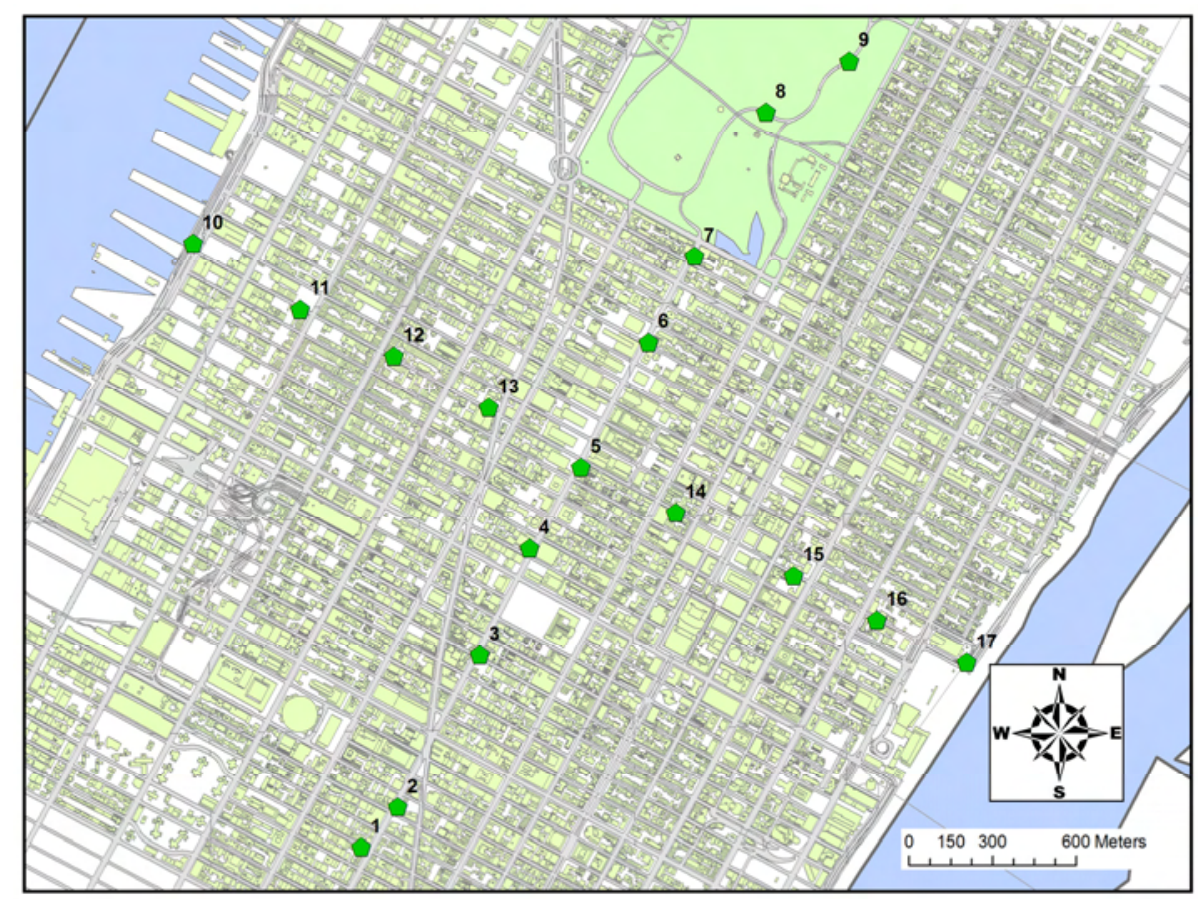

Figure 3.23. MID05 HOBO® Temperature Sensor Positions

In summary, the meteorological instruments deployed as part of MID05 were 5 roof-top 3-D sonic anemometers on 6-meter tripods stations, 10 street-level 3-D sonic anemometers on 3-meter tripods, two roof-top sodars measuring winds to $~ 200 \mathrm{~m}$ above the instrument in 10-meter increments beginning at $20 \mathrm{~m}$, one radar wind profiler measuring winds to $\sim 2500 \mathrm{~m}$ above the instrument in 60-meter increments beginning at $150 \mathrm{~m}$, one radiosonde system measuring winds, temperature, humidity, and pressure from the surface up to several kilometers above the surface, and 17 HOBO ${ }^{\circledR}$ temperature instruments. The 15 sonics collected turbulence data at $10 \mathrm{~Hz}$, the sodars provided 2-minute-average wind data, the radar wind profiler provided 30-minute-average wind data, and the HOBOs ${ }^{\circledR}$ provided 5-minute-average data. The 5 roof-top sonics, 2 roof-top sodars, $17 \mathrm{HOBOs}{ }^{\circledR}$, and the radar wind profiler provided data continuously throughout the August study period (other than during instrument failures). The 10 street-level sonics and the radiosonde system provided data during the IOPs. 


\subsection{Final MID05 Data Set}

The data collected during the Midtown Manhattan August 2005 field study (MID05) have been assembled into a final data set for distribution to researchers. The tracer information, as described previously, will be distributed only to those with a need to know.

The tracer data collected during the six intensive observation periods have been examined thoroughly by PNNL to determine the quality of the data. The final tracer dataset that has been assembled by PNNL has had the mean background concentration of each tracer compound removed from the measurement so that direct comparisons may be made with model output. Furthermore, any suspect data have been removed so that only those values that can be confidently used for analysis are included. The original data files delivered to PNNL from the institutions that measured and analyzed the data are also included for reference.

The meteorological data have also been reviewed by PNNL in addition to the quality control performed by the institution that collected the data. The raw meteorological data are provided as part of the final MID05 data set. Also included are various averaging periods (5-, 10-, 15-, 30-, and 60-minute averages) that have been computed by the Harvard School of Public Health for the rooftop and streetlevel sonic anemometers.

To complete the documentation of the number and variety of instruments deployed for this field campaign, GIS layers have been created on a detailed map of the Midtown area. The map file, created in ArcMap 9.0, as well as the accompanying database file with each of the map layers, has also been included as part of the final MID05 data set.

The MID05 data archive is available from PNNL upon request (contact jerry.allwine@pnl.gov or julia.flaherty@pnl.gov). The archive is about 3 GB and is contained on one DVD. Readme files accompanying each component of the archive describe the contents and structure of the archive. 


\subsection{References}

Allwine KJ, JH Shinn, GE Streit, KL Clawson, and M Brown. 2002. “An overview of URBAN 2000: A multi-scale field study of dispersion through an urban environment.” Bull. Amer. Meteor. Soc.

83:521-536.

Allwine KJ, MJ Leach, LW Stockham, JS Shinn, RP Hosker, JF Bowers, and JC Pace. 2004. “Overview of Joint Urban 2003 - An Atmospheric Dispersion Study in Oklahoma City.” Preprints, 84 ${ }^{\text {th }}$ AMS Annual Meeting, Seattle, WA. Amer. Meteor. Soc., J7.1

Allwine KJ, and JE Flaherty. 2006. Urban Dispersion Program MSG05 Field Study: Summary of Tracer and Meteorological Measurements. PNNL-15969, Pacific Northwest National Laboratory, Richland, WA.

Reynolds RM. 2006. The Madison Square Garden Dispersion Study (MSG-05) Meteorological Data Report. BNL-77144-2006-IR. Brookhaven National Laboratory, Upton, NY.

Reynolds RM, TM Sullivan, and S Smith. 2007. The New York Midtown Dispersion Study (MID-05) Meteorological Data Report. BNL Interim Report, Brookhaven National Laboratory, Upton, NY.

Watson TB, J Heiser, P Kalb, RN Dietz, R Wilke, R Wieser, and G Vignato. 2006. The New York City Urban Dispersion Program March 2005 Field Study: Tracer Methods and Results. BNL-75592-2006, Brookhaven National Laboratory, Upton, NY. 


\section{Appendix A}

\section{UDP Wrap-Up Memo and Publications}




\section{Appendix A: UDP Wrap-Up Memo and Publications}

Given in this appendix is an email memorandum dated June 1, 2007, from the Department of Homeland Security’s UDP Program Manager Dr. Thomas Kiess, officially concluding the Urban Dispersion Program. Also included in this appendix is the list of 56 completed and in-press publications, reports, and presentations funded or partly funded within UDP.

\section{A.1 UDP Wrap-Up Memorandum (June 1, 2007)}

To All Parties Interested in the DHS-S\&T Urban Dispersion Program (UDP) -

The UDP has been a productive effort to gather data in order to enhance the study of atmospheric dispersion of airborne materials that are released in a complex urban environment such as New York City (NYC). We in the Department of Homeland Security (DHS) Science and Technology (S\&T) Directorate intend for this brief communication to overview some shared successes that form the UDP legacy, describe the remaining work that is drawing to a close, and offer some perspectives as this program winds down about future expectations that we believe are reasonable.

Many of you who receive this email have your own history and associations with the UDP effort. We do not intend to provide a comprehensive UDP overview here. Instead, we refer you to the UDP public web site (http://urbandispersion.pnl.gov/) for overview information and a link to presentations given to the New York Academy of Sciences (NYAS) on March 16, 2006. The NYAS presentations describe the overall program, and the modeling, field study and the meteorological network components of UDP. Additional reference information is some presentations made to NYC audiences, most notably the following:

- the 24 August 2006 briefing at OEM (this briefing is cleared for release to a broad audience, including the general public);

- the 20 April 2007 phone briefing to NYC agencies (this briefing is "For Official Use Only" with controlled distribution); and

- the 4 May 2007 briefing at NYPD (this briefing is also "For Official Use Only" with controlled distribution).

Copies of these briefings are available from Jerry Allwine (jerry.allwine@pnl.gov), the UDP lead scientist and project manager.

As shown in these presentations, and upon reflection, we think that the data sets of tracer gas releases in Manhattan that were conducted in March and August 2005 together form a key outcome of UDP upon which other insights are derived. These data are being finalized for access by atmospheric dispersion modelers. We project that studies (some underway now) using these data can be fruitful for several years, as model developers seek to calibrate modeled effects against the observed urban dispersive behaviors documented by the UDP data sets. Based on the use of other data sets (e.g. taken in Oklahoma City in 2003 and in Salt Lake City in 2000) of large-scale tracer experiments, we think that the UDP data may see years of productive use by modelers in order for them to ultimately develop improved modeling tools that account for urban fate and transport effects in the UDP measurements. To be clear, the smaller data sets of March 2005 are available broadly because they do not reveal any new or potentially sensitive 
information about air flows in cities. However, the larger August 2005 data sets will have restricted access once finalized.

Based on a preliminary analysis of the UDP data, Jerry and his team have derived some response guidance ("rules of thumb") as shown in the three presentations identified above. Jerry is seeking to document this information more formally in a UDP summary report that will be completed by July 2007.

One local-to-NYC UDP legacy is an expanded meteorological network augmenting the set of instruments already in place in the NYC area. The UDP meteorological network was installed to support the 2005 tracer tests. This network enables near real-time access to some quality meteorological data (e.g., wind speed and direction, in several strategic locations in and surrounding Manhattan) that has many uses. Jerry's team is transitioning that network to a NYC university, the City College of New York, for their maintenance and use in further meteorological research that they plan to undertake. This transition is planned for completion by the end of 2007.

Therefore, we would like to declare that the UDP effort as we have known it is drawing to a close. The final wrap-up activities will be Jerry's remaining efforts to develop the mid-town August 2005 data sets for restricted access, to write a summary report, and to finish the local met network transition. These will be accomplished without much fanfare, and so we are not planning any further coordinated briefings or large meetings in NYC.

Of course, the UDP was a team effort, involving not just the performers, but also interested and affected parties in NYC government and in other agencies. We hope that this team has left a positive impression on all whom they interacted with regarding their professionalism and abilities.

The UDP team has generated useful outcomes - data sets, some preliminary data evaluations in order to improve models, "rules of thumb” response guidance, and an enhanced local-to-NYC meteorological network - of which they can be proud to have generated. These outcomes are available for others (e.g., modelers, emergency response planners, and future researchers) to inherit for their follow-on uses.

We hope you agree that the UDP has been a worthwhile effort. We hope you too have enjoyed the occasions to be involved in helping to plan or conduct UDP activities, or to otherwise attend briefings to hear about them. We are always open-minded to hear constructive critique or commentary of others' perspectives of lessons learned that we can take to heart. To that end, please feel free to contact either Jerry or me.

In closing, we thank you for the support and interest in UDP. We hope you too have positive experiences and memories of this program.

Thomas E. Kiess, Ph.D.

Team Lead, Laboratory Coordination and Utilization

Office of National Laboratories

Science and Technology Directorate

U.S. Department of Homeland Security

Washington, DC 20528

Ph (202) 254-6015ＦAX (202) 254-6178 email Thomas.Kiess@dhs.gov 


\section{A.2 UDP Publications, Reports, and Presentations}

\section{JOURNAL PUBLICATIONS:}

Hanna SR, J White, and Y Zhou. 2007. “Observed Winds, Turbulence, And Dispersion In Built-Up Downtown Areas In Oklahoma City And Manhattan.” Submitted to Boundary Layer Meteor.

Hanna SR, MJ Brown, FE Camelli, ST Chan, WJ Coirier, OR Hansen, AH Huber, S Kim, and RM Reynolds. 2006. "Detailed Simulations Of Atmospheric Flow And Dispersion In Downtown Manhattan.” Bulletin Am. Meteorol. Soc. 87(12):1713-1726

Holt T, and J Pullen. 2007. "Urban Canopy Modeling Of The New York City Metropolitan Area: A Comparison And Validation Of Single-Layer And Multi-Layer Parameterizations.” Mon. Wea. Rev. 135:1906-1930.

Jones M, BA Colle, and J Tongue. 2007. "Evaluation Of A Short-Range Ensemble Forecast System Over The Northeast U.S.” Wea. Forecasting 22:36-55.

Novak D, and BA Colle. 2006. “Observations of Multiple Sea Breeze Boundaries during an Unseasonably Warm Day in Metropolitan New York City.” Bull. Amer. Meteor. Soc. 87:169-174.

Pullen J, T Holt, A Blumberg, and B Bornstein. 2007. “Atmospheric Response To Local Upwelling In The Vicinity Of New York/New Jersey Harbor.” J. Appl. Meteor. Climatol., in press.

Thompson W, T Holt, and J Pullen. 2007. "Investigation Of A Sea Breeze Front In An Urban Environment.” Quart. J. Roy. Meteor. Soc. 133:579-594.

Watson TB, R Wilke, RN Dietz, J Heiser, and P Kalb. 2007. “The Atmospheric Background of Perfluorocarbon Compounds Used as Tracers.” Submitted to Environmental Science and Technology.

\section{REPORTS:}

Allwine KJ, and JE Flaherty. 2006. Urban Dispersion Program MSG05 Field Study: Summary of Tracer and Meteorological Measurements. PNNL-15969, Pacific Northwest National Laboratory, Richland, WA.

Allwine KJ, and JE Flaherty. 2007. Urban Dispersion Program MID05 Field Study: Analysis of Tracer Measurements, Significant Findings and First-Responder Guidance. Pacific Northwest National Laboratory, Richland, WA. [Limited Distribution - "For Official Use Only”]

Allwine KJ, and JE Flaherty. 2007. Urban Dispersion Program Overview and MID05 Field Study Summary. PNNL-16696, Pacific Northwest National Laboratory, Richland, WA.

Berg LK, and KJ Allwine. 2006. Deployment Notes for Sodars at the Stevens Institute of Technology during the March 2005 Urban Dispersion Program Field Campaign (MSG05). PNNL-15945, Pacific Northwest National Laboratory, Richland, WA.

Burian S, A McKinnon, J Hartman, W Han. 2005. National Building Statistics Database: New York City. LA-UR-05-8154, Los Alamos National Laboratory, Los Alamos, NM. 
Clawson KL, RG Carter, DJ Lacroix, JD Rich, D Finn, NF Hukari, and T Strong. 2006. Midtown Manhattan 2005 (MID05) SF6 Atmospheric Tracer Field Tests. NOAA Technical Memorandum OAR ARL-258 Air Resources Laboratory Field Research Division. Idaho Falls, ID. [Limited Distribution “Official Use Only”]

Heiser J, T Watson, and J Allwine. 2007. Perfluorocarbon Tracer Dispersion Studies in the New York Subway System. BNL 77946-2007, Brookhaven National Laboratory, Upton, NY. [Limited Distribution - “Official Use Only”]

Heiser J, T Watson, and J Allwine. 2007. Perfluorocarbon Tracer Dispersion Studies in the New York Subway System-Extended Abstract. BNL 77946-2007-AB, Brookhaven National Laboratory, Upton, NY. [Limited Distribution - "Official Use Only”]

Reynolds RM, TM Sullivan, and S Smith. 2007. The New York Midtown Dispersion Study (MID-05) Meteorological Data Report. BNL 77945-2007-IR, Brookhaven National Laboratory, Upton, NY.

Reynolds RM. 2006. The Madison Square Garden Dispersion Study (MSG-05) Meteorological Data Report. BNL-77144-2006-IR, Brookhaven National Laboratory, Upton, NY.

Senocak G, and M Brown. 2007. Evaluation of the QUIC Fast Response Dispersion Modeling System with the New York City Madison Square Garden (MSG05) Field Study: IOP1, Release 2. Los Alamos National Laboratory, Los Alamos, NM.

Watson TB, J Heiser, P Kalb, RN Dietz, R Wilke, and J Adams. 2007. The New York City Urban Dispersion Program August 2005 Field Study: Tracer Methods and Results. BNL 77986-2007, Brookhaven National Laboratory, Upton, NY. [Limited Distribution - “Official Use Only”]

Watson TB, J Heiser, P Kalb, RN Dietz, R Wilke, R Wieser, and G Vignato. 2006. The New York City Urban Dispersion Program March 2005 Field Study: Tracer Methods and Results. BNL-75592-2006, Brookhaven National Laboratory, Upton, NY.

\section{CONFERENCE PAPERS AND PRESENTATIONS}

Allwine J, J Heiser, J Flaherty, T Watson, K Clawson, and P Kalb. 2007. “Urban Dispersion Program: Guidance for Airborne Releases.” PNNL-SA-55204. New York City Interagency Phone Briefing. Pacific Northwest National Laboratory, Richland, WA. April 24, 2007. [Limited Distribution - "For Official Use Only"]

Allwine J. 2007. "UDP New York City Meteorological Network (NYC MetNet) Transition to CUNY.” PNNL-SA-55779. NYC MetNet Transition Meeting. City College of New York, New York City, NY. June 4, 2007.

Allwine KJ, K Clark, B Bornstein, T Watson, and M Brown. 2006. "Urban Dispersion Program: Measuring and Modeling Atmospheric Dispersion in New York City.” PNNL-SA-48895, New York Academy of Sciences Atmospheric Sciences Section Meeting. New York City, NY. March 16, 2006.

Allwine KJ. 2005. “Advances in Atmospheric Dispersion Modeling in Urban Areas.” PNNL-SA-45330. Applied Modeling and Computations in Nuclear Science. 230 ${ }^{\text {th }}$ ACS National Meeting. Washington, DC, August 29, 2005. 
Allwine KJ. 2006. "Overview of the Urban Dispersion Program’s New York City Field Studies”" PNNL-SA-51129, Presented at 10th Annual George Mason University Conference on Atmospheric Transport and Dispersion Modeling, Fairfax, VA, August 1-3, 2006.

Allwine KJ. 2005. “The Department of Homeland Security NYC Urban Dispersion Program.” PNNLSA-47353. 2005 Eastern Analytical Symposium, Somerset, New Jersey, November 15, 2005.

Berg LK, and KJ Allwine. 2007. "Urban Dispersion Program: Deployment of Boundary-Layer Wind Profiler at the Liberty Science Center.” PNNL-SA-55106, Liberty Science Center, Jersey City, N.J. April 30, 2007.

Berg LK, RM Reynolds, KJ Allwine, and A Blumberg. 2006. "Comparisons of Measurements Made Using Two Sodars in an Urban Environment.” PNNL-SA-48320, In 86th Annual Meeting of the American Meteorological Society, Atlanta, GA, January 29 - February 2, 2006.

Bornstein RD, R Balmori, E Weinroth, and H Taha. 2007. "Urbanized MM5 simulations for a Houston ozone episode and for the NYC DHS MSG tracer study.” To Be Presented at 11th Annual George Mason University Conference on Atmospheric Transport and Dispersion Modeling, Fairfax, VA, July 10-12, 2007.

Brown M, S Pol, W Coirier, S Kim, A Huber, M Nelson, P Klein, and A Gowardhan. 2006.

"Experimental And Model-Computed Area-Averaged Vertical Profiles Of Wind Speed For Evaluation Of Mesoscale Urban Canopy Schemes.” LA-UR-05-8025, In 86th Annual Meeting of the American Meteorological Society, Atlanta, GA, January 29 - February 2, 2006.

Brown M. 2006. “NYC Urban Dispersion Program Urban Dispersion Modeling Component.” New York Academy of Sciences Atmospheric Sciences Section Meeting, New York City, NY. March 16, 2006.

Brown MJ. 2007. "Urban transport and dispersion - Uncertainty, evaluation, and probabilistic methods." To Be Presented at 11th Annual George Mason University Conference on Atmospheric Transport and Dispersion Modeling, Fairfax, VA, July 10-12, 2007.

Camelli FE, SR Hanna, and R Lohner. 2005. "Very Large Eddy Simulation (VLES) Study Of Flow And Dispersion Patterns In Midtown Manhattan.” Presented at 9th Annual George Mason University Conference on Atmospheric Transport and Dispersion Modeling, Fairfax, VA, July 18-20, 2005.

Camelli FE, SR Hanna, and R Lohner. 2006. "FEFLO CFD Model Study Of Flow And Dispersion As Influenced By Tall Buildings In New York City.” In 86th Annual Meeting of the American Meteorological Society, Atlanta, GA, January 29 - February 2, 2006.

Camelli FE, WJ Coirier, AH Huber, OR Hansen, S Kim, SR Hanna, and MJ Brown. 2006. “An Intercomparison Of Four Computational Fluid Dynamics Models: Transport And Dispersion About Madison Square Garden.” In 86th Annual Meeting of the American Meteorological Society, Atlanta, GA, January 29 - February 2, 2006.

Camelli FR Lohner, and SR Hanna. 2005. “Dispersion Patterns In Heterogeneous Urban Areas.” Presented at Department of Homeland Security Conference on Working Together: Research \& Development Partnerships in Homeland Security, Boston, MA. April 27-28, 2005.

Coirier WJ, and S Kim. 2006. "CFD Modeling For Urban Area Contaminant Transport And Dispersion: Model Description And Data Requirements.” In 86th Annual Meeting of the American Meteorological Society, Atlanta, GA, January 29 - February 2, 2006. 
Coirier WJ, and S Kim. 2006. "Summary Of CFD-Urban Results In Support Of The Madison Square Garden And Urban Dispersion Program Field Tests.” In 86th Annual Meeting of the American Meteorological Society, Atlanta, GA, January 29 - February 2, 2006.

Coirier WJ, and SX Kim. 2005. "Detailed Transport And Dispersion Calculations In Support Of The MSG05 Field Test.” Presented at 9th Annual George Mason University Conference on Atmospheric Transport and Dispersion Modeling, Fairfax, VA, July 18-20, 2005.

Coirier WJ, and SX Kim. 2005. "Recent Developments And Applications Of The CFD-Urban Transport And Dispersion Model.” Presented at 9th Annual George Mason University Conference on Atmospheric Transport and Dispersion Modeling, Fairfax, VA, July 18-20, 2005.

Hanna S, and Y Zhou. 2007. "Results of Analysis of Sonic Anemometer Observations at Street Level and at Rooftop in Manhattan." $5^{\text {th }}$ International Conference on Urban Air Quality. Cyprus. March 2729, 2007.

Hanna S, J White, Y Zhou, and A Kosheleva. 2006. “Analysis of Joint Urban 2003 (JU2003) and Madison Square Garden 2005 (MSG05) meteorological and tracer data.” In 86th Annual Meeting of the American Meteorological Society, Atlanta, GA, January 29 - February 2, 2006.

Hanna S, KJ Allwine, and JE Flaherty. 2006. “Urban Dispersion Program (UDP) Field Experiments.” Presented at DTRA Technical Panel 9 Meeting. Salt Lake City, UT, February 14, 2006.

Hanna SR, and Y Zhou. 2006. “Turbulence at Street-Level in Built-Up Urban Downtown Areas.” Presented at 10th Annual George Mason University Conference on Atmospheric Transport and Dispersion Modeling, Fairfax, VA, August 1-3, 2006.

Hanna SR, J Heiser, and M Reynolds. 2005. "Overview of Madison Square Garden (MSG05) Field Experiment.” Presented at 9th Annual George Mason University Conference on Atmospheric Transport and Dispersion Modeling, Fairfax, VA, July 18-20, 2005.

Hanna SR, M Reynolds, J Heiser, and R Bornstein. 2004. “Plans For The Madison Square Garden 2004 (MSG04) Tracer Experiment In Manhattan.” In Fifth Symposium on the Urban Environment, August 2327, 2004, Vancouver, British Columbia, Canada. American Meteorological Society, Boston, MA.

Holt T, and J Pullen. 2005. "Urban Canopy And Dynamic Sea Surface Temperature Effects On Plume Transport In The New York City Metropolitan Area.” Presented at 9th Annual George Mason University Conference on Atmospheric Transport and Dispersion Modeling, Fairfax, VA, July 18-20, 2005.

Holt TR, and J Pullen. 2006. "Relative Impact Of Two Urban Canopy Parameterizations On Coastal Urban Processes." In 86th Annual Meeting of the American Meteorological Society, Atlanta, GA, January 29 - February 2, 2006.

Kim S, and W Coirier. 2006. “Assessment Of Velocity And Turbulence Boundary Condition Treatments Upon The In-Canopy Wind, Turbulence And Transport And Dispersion Behavior In Midtown Manhattan.” In 86th Annual Meeting of the American Meteorological Society, Atlanta, GA, January 29 February 2, 2006.

Leach MJ, ST Chan, and JK Lundquist. 2006. "High-Resolution CFD Simulation Of Airflow And Tracer Dispersion In New York City.” In 86th Annual Meeting of the American Meteorological Society, Atlanta, GA, January 29 - February 2, 2006. 
Lee HN, RM Reynolds, and BB Hicks. 2003. "Urban Atmospheric Observatory (UAO).” Presented at 7th Annual George Mason University Conference on Atmospheric Transport and Dispersion Modeling, Fairfax, VA, June 17-19, 2005.

Monache LD, JC Weil, MJ Leach, JM Leone, and GA Loosmore. 2007. “An urban boundary layer and dispersion parameterization for the LLNL NARAC modeling system: Preliminary tests with the Joint Urban 2003 Field Project Data Set.” To Be Presented at 11th Annual George Mason University Conference on Atmospheric Transport and Dispersion Modeling, Fairfax, VA, July 10-12, 2007.

Pullen J, T Young, G Patnaik, T Holt, and J Boris. 2005. “Linked Mesoscale-LES Contaminant Prediction For Manhattan.” Presented at 9th Annual George Mason University Conference on Atmospheric Transport and Dispersion Modeling, Fairfax, VA, July 18-20, 2005.

Pullen J, TR Holt, A Blumberg, and BA Colle. 2006. "High-Resolution Modeling For NYC: Coastal Ocean And Urbanization Effects.” In 86th Annual Meeting of the American Meteorological Society, Atlanta, GA, January 29 - February 2, 2006.

Reynolds RM, RD Bornstein, SR Hanna, T Oke, BB Hicks, and H-N Lee. 2004. “The New York City Urban Atmospheric Observatory - An Overview.” In Symposium on Planning, Nowcasting and Forecasting in the Urban Zone, Seattle, WA on January 11-15, 2004. American Meteorological Society, Boston, MA.

Sullivan TM, JH Heiser, T Watson, KJ Allwine, and JE Flaherty. 2006. "Perfluorocarbon Gas Tracer Studies to Support Risk Assessment Modeling of Critical Infrastructure Subjected to Terrorist Attacks.” BNL-NUREG-76941-2006-IR. In NATO Advanced Research Workshop, Computational Models of Risks to Infrastructure, Primosten, Croatia, May 6-13, 2006.

Thompson WT, T Holt, and J Pullen. 2006. “Atmospheric Transport And Dispersion Associated With A Sea Breeze Front In An Urban Environment.” Presented at 10th Annual George Mason University Conference on Atmospheric Transport and Dispersion Modeling, Fairfax, VA, August 1-3, 2006.

Wissink A, B Kosovic, K Chand, T Chow, B Gunney, C Kapfer, and S Chan. 2005. “High-Resolution Prediction Of Airborne Dispersion Around Buildings: The Automated Urban Dispersion Integrated Model - AUDIM.” Presented at Department of Homeland Security Conference on Working Together: Research \& Development Partnerships in Homeland Security, Boston, MA. April 27-28, 2005. 


\section{Appendix B}

Coordinates of MID05 Tracer Releases and Samplers 


\section{Appendix B: Coordinates of MID05 Tracer Releases and Samplers}

The following tables give the location, description, and coordinates of the tracer samplers deployed during MID05. Latitude and longitude are in degrees north of the equator and west of the prime meridian, respectively. Easting and northing coordinates are in Universal Transverse Mercator (UTM) Zone 18 referenced to the 1983 North American Datum (NAD83).

An extremely important aspect of any urban field study is the accurate representation of instrument locations. The coordinates of the MID05 instruments were defined by positioning the instruments within a geographic information systems (GIS) map with a Universal Transverse Mercator (UTM) Zone 18 coordinate system using the 1983 North American Datum (NAD) with the detailed building and road databases for the Midtown Manhattan area. GoogleEarth (www.earth.google.com) and Windows Live Local (http://maps.live.com) were also valuable resources for refining instrument positions when field photographs were available.

Most of the coordinates reported in this document have an accuracy level within 2 meters. Other positions, such as those for the subway releases and samplers, were difficult to pinpoint with GoogleEarth, Windows Live Local, or ArcMap, so we estimate that the positions are within about 10 meters of the true location. All coordinates have been checked with the principal investigators responsible for the instrumentation to verify that the best possible position is reported in this document.

Table B.1. MID05 Release Location Coordinates

\begin{tabular}{|c|c|c|c|c|c|}
\hline Release ID & Location Description & $\begin{array}{c}\text { Latitude } \\
\text { (deg) }\end{array}$ & $\begin{array}{c}\begin{array}{c}\text { Longitude } \\
\text { (deg) }\end{array} \\
\end{array}$ & $\begin{array}{c}\text { Easting } \\
\text { (m) }\end{array}$ & $\begin{array}{c}\text { Northing } \\
\text { (m) }\end{array}$ \\
\hline SW & S side $44^{\text {th }}$ St. W of $7^{\text {th }}$ Ave. & 40.75748 & 73.98649 & 585550 & 4512330 \\
\hline SW-1 & S side $44^{\text {th }} \mathrm{W}$ of $7^{\text {th }}-$ to the east of SW & 40.75740 & 73.98629 & 585567 & 4512321 \\
\hline $\mathrm{S}$ & S side $45^{\text {th }}$ St. btwn $6^{\text {th }} \& 7^{\text {th }}$ Aves. & 40.75698 & 73.98335 & 585816 & 4512277 \\
\hline SE & S side $47^{\text {th }}$ St. W of $5^{\text {th }}$ Ave. & 40.75689 & 73.97926 & 586161 & 4512271 \\
\hline$\overline{C L}$ & W of $6^{\text {th }}$ Ave. on S side $49^{\text {th }}$ St. & 40.75969 & 73.98211 & 585917 & 4512579 \\
\hline CR & $6^{\text {th }}$ Ave btwn $49^{\text {th }} \& 50^{\text {th }}$ Sts. & 40.75941 & 73.98063 & 586042 & 4512550 \\
\hline $\mathrm{NE}$ & $\mathrm{N}$ side $54^{\text {th }}$ St. btwn $6^{\text {th }} \& 7^{\text {th }}$ Aves. & 40.76266 & 73.97908 & 586169 & 4512912 \\
\hline ENE & S side $53^{\text {rd }}$ St. btwn $6^{\text {th }} \& 5^{\text {th }}$ Aves. & 40.76100 & 73.97737 & 586315 & 4512729 \\
\hline SU & $50^{\text {th }}$ St. subway station - uptown side & 40.76188 & 73.98364 & 585785 & 4512821 \\
\hline SD & $50^{\text {th }}$ St. subway station - downtown side & 40.76184 & 73.98388 & 585765 & 4512816 \\
\hline
\end{tabular}


Table B.2. Street-Level Integrating Tracer Sampler Coordinates. Samplers were mounted on light poles at $~ 3$ to $3.5 \mathrm{~m}$ AGL. (Samplers at 28a and 37a were deployed on the ground at less than $1 \mathrm{~m}$ AGL.) " $X$ " in the "PFT only" column indicates that the sampler locations had only PFT measurements. All other locations had both PFT and $\mathrm{SF}_{6}$ measurements. Sampling locations 4, 8, and 61 were not used during the study. The coordinates are for samplers PIGS-SF 6 , PIGS-PFT, and BATS-PFT (see Section 3.4.1).

\begin{tabular}{|c|c|c|c|c|c|c|}
\hline $\begin{array}{c}\text { Sampler } \\
\#\end{array}$ & Location Description & $\begin{array}{l}\text { PFT } \\
\text { only }\end{array}$ & $\begin{array}{c}\text { Latitude } \\
\text { (deg) }\end{array}$ & $\begin{array}{c}\text { Longitude } \\
\text { (deg) }\end{array}$ & $\begin{array}{c}\text { Easting } \\
(\mathrm{m})\end{array}$ & $\begin{array}{c}\text { Northing } \\
(\mathbf{m})\end{array}$ \\
\hline 1 & $\mathrm{~N}$ side 41 st $\mathrm{W}$ of $9^{\text {th }}$ & $\mathrm{X}$ & 40.75808 & 73.99338 & 584968 & 4512390 \\
\hline 2 & S side 41 st $\mathrm{E}$ of $9^{\text {th }}$ & $\mathrm{X}$ & 40.75733 & 73.99231 & 585059 & 4512307 \\
\hline 3 & $\mathrm{~N}$ side 41 st btwn 8 th $\& 7^{\text {th }}$ & $\mathrm{X}$ & 40.75600 & 73.98880 & 585357 & 4512163 \\
\hline 4 & W side 7 th $\mathrm{N}$ of $41^{\text {st }}$ (NOT USED) & $\mathrm{X}$ & 40.75560 & 73.98740 & 585476 & 4512120 \\
\hline 5 & $\mathrm{~N}$ side 41st btwn Broadway $\& 6^{\text {th }}$ & $\mathrm{X}$ & 40.75467 & 73.98563 & 585626 & 4512018 \\
\hline 6 & E of AvAmerica on S side $42^{\text {nd }}$ & $\mathrm{X}$ & 40.75447 & 73.98344 & 585811 & 4511999 \\
\hline 7 & W side of 5th near 41st & $\bar{X}$ & 40.75278 & 73.98152 & 585976 & 4511813 \\
\hline 8 & N side 41st btwn Madison \& Park (NOT USED) & $\mathrm{X}$ & 40.75207 & 73.97948 & 586149 & 4511736 \\
\hline 9 & N side 44th btwn Madison \& Vanderbilt & $\mathrm{X}$ & 40.75395 & 73.97784 & 586285 & 4511946 \\
\hline 10 & W of 5th on $\mathrm{N}$ side of 44 th & - & 40.75503 & 73.98042 & 586066 & 4512064 \\
\hline 11 & E of AvAmerica on $N$ side of 44th & - & 40.75576 & 73.98215 & 585919 & 4512143 \\
\hline 12 & E of Broadway on S side of 44th & - & 40.75649 & 73.98412 & 585751 & 4512222 \\
\hline 13 & W side of 7th $\mathrm{N}$ of 44th & - & 40.75781 & 73.98581 & 585607 & 4512367 \\
\hline 14 & $\mathrm{E}$ of 8th on $\mathrm{N}$ side of 44th & - & 40.75824 & 73.98804 & 585418 & 4512413 \\
\hline 15 & E of 9th on S side of 44th & - & 40.75920 & 73.99056 & 585204 & 4512517 \\
\hline 16 & S side 44th W of 9th & $\bar{X}$ & 40.75991 & 73.99225 & 585061 & 4512594 \\
\hline 17 & $\mathrm{~N}$ side 46th $\mathrm{W}$ of 9th & $\mathrm{X}$ & 40.76125 & 73.99128 & 585141 & 4512744 \\
\hline 18 & $\mathrm{E}$ of 9th on $\mathrm{N}$ side 46 th & - & 40.76046 & 73.98942 & 585299 & 4512658 \\
\hline 19 & E of 8th on S side of 46th & - & 40.75943 & 73.98723 & 585485 & 4512545 \\
\hline 20 & W side of 7th $S$ side of 46th & - & 40.75864 & 73.98547 & 585635 & 4512459 \\
\hline 21 & E of 7th on $S$ side 46th & - & 40.75783 & 73.98343 & 585808 & 4512371 \\
\hline 22 & E of AvAmerica on $\mathrm{N}$ side 46th & - & 40.75677 & 73.98064 & 586045 & 4512256 \\
\hline 23 & E of 5th on S side of 46th & - & 40.75574 & 73.97847 & 586229 & 4512144 \\
\hline 24 & $\mathrm{~N}$ side 46th btwn Madison \& Vande & $\mathrm{X}$ & 40.75524 & 73.97701 & 586353 & 4512090 \\
\hline 25 & N side 49th btwn Madison \& Park & $\mathrm{X}$ & 40.75693 & 73.97522 & 586502 & 4512280 \\
\hline 26 & E of 5th on N side 49th & - & 40.75772 & 73.97705 & 586347 & 4512365 \\
\hline 27 & E of AvAmerica on S side 49th & - & 40.75848 & 73.97914 & 586169 & 4512448 \\
\hline $28 a$ & $\begin{array}{l}\text { W of AvAmerica on S side 49th } \\
\text { (during IOP } 1 \text { \& 2) }\end{array}$ & - & 40.75969 & 73.98211 & 585917 & 4512579 \\
\hline $28 b$ & $\begin{array}{l}\text { W of AvAmerica on S side } 49^{\text {th }} \\
\text { (during IOPs 3-6) }\end{array}$ & - & 40.75962 & 73.98186 & 585938 & 4512572 \\
\hline 29 & E of 7th on $\mathrm{N}$ side 49th & - & 40.76028 & 73.98315 & 585828 & 4512644 \\
\hline 30 & E of 8th on $S$ side 49th & - & 40.76132 & 73.98590 & 585595 & 4512757 \\
\hline 31 & E of 9th on S side 49th & - & 40.76223 & 73.98801 & 585416 & 4512855 \\
\hline 32 & $\mathrm{~N}$ side 49 th $\mathrm{W}$ of 9 th & $\mathrm{X}$ & 40.76324 & 73.99014 & 585235 & 4512965 \\
\hline 33 & S side 51st W of 9th & $\mathrm{X}$ & 40.76431 & 73.98908 & 585323 & 4513085 \\
\hline 34 & $\mathrm{E}$ of 9th on $\mathrm{N}$ side $51 \mathrm{st}$ & - & 40.76358 & 73.98707 & 585493 & 4513006 \\
\hline 35 & E of 8th on $S$ side 51st & - & 40.76262 & 73.98510 & 585661 & 4512902 \\
\hline 36 & W side of 7th $\mathrm{N}$ side of 51st & - & 40.76184 & 73.98286 & 585851 & 4512817 \\
\hline
\end{tabular}


Table B.2 Cont'd

\begin{tabular}{|c|c|c|c|c|c|c|}
\hline$\underset{\#}{\text { Sampler }}$ & Location Description & $\begin{array}{l}\text { PFT } \\
\text { only }\end{array}$ & $\begin{array}{c}\text { Latitude } \\
\text { (deg) }\end{array}$ & $\begin{array}{l}\begin{array}{l}\text { Longitude } \\
\text { (deg) }\end{array} \\
\end{array}$ & $\begin{array}{c}\begin{array}{c}\text { Easting } \\
(\mathrm{m})\end{array} \\
\end{array}$ & $\begin{array}{l}\text { Northing } \\
\text { (m) }\end{array}$ \\
\hline $37 a$ & $\begin{array}{l}\text { Btwn 50th \& 51st on E side of AvAmerica } \\
\text { (during IOPs 1-3) }\end{array}$ & - & 40.76021 & 73.98004 & 586091 & 4512639 \\
\hline $37 \mathrm{~b}$ & $\begin{array}{l}\text { W of AvAmerica on S side of 51st } \\
\text { (during IOPs 4-6) }\end{array}$ & - & 40.76088 & 73.98097 & 586012 & 4512713 \\
\hline 38 & E of AvAmerica on S side of 51st & - & 40.75973 & 73.97823 & 586244 & 4512588 \\
\hline 39 & $\mathrm{E}$ of 5 th on $\mathrm{N}$ side of $51 \mathrm{st}$ & - & 40.75875 & 73.97563 & 586465 & 4512481 \\
\hline 40 & N side of 51st btwn Madison \& Park & $\mathrm{X}$ & 40.75813 & 73.97416 & 586590 & 4512414 \\
\hline 41 & S side 54th btwn Madison \& Park & $\mathrm{X}$ & 40.76000 & 73.97304 & 586682 & 4512623 \\
\hline 42 & W side of 5th on $\mathrm{N}$ side of 54th & - & 40.76114 & 73.97543 & 586479 & 4512747 \\
\hline 43 & E of AvAmerica on $\mathrm{N}$ side 54th & - & 40.76221 & 73.97803 & 586258 & 4512863 \\
\hline 44 & W of AvAmerica on S side 54th & - & 40.76279 & 73.97969 & 586117 & 4512926 \\
\hline 45 & S side of 7th S side of 54th & - & 40.76357 & 73.98159 & 585956 & 4513011 \\
\hline 46 & E of 8th on $N$ side 54th & - & 40.76446 & 73.98335 & 585806 & 4513107 \\
\hline 47 & E of 9th on $N$ side 54th & - & 40.76546 & 73.98572 & 585605 & 4513216 \\
\hline 48 & $\mathrm{~N}$ side 54 th $\mathrm{W}$ of 9 th & $\mathrm{X}$ & 40.76625 & 73.98758 & 585447 & 4513302 \\
\hline 49 & S side of 56th W of 9th & $\mathrm{X}$ & 40.76750 & 73.98695 & 585498 & 4513442 \\
\hline 50 & E of 9th on S side 56th & - & 40.76632 & 73.98416 & 585735 & 4513313 \\
\hline 51 & E of 8th on $N$ side 56th & - & 40.76567 & 73.98234 & 585890 & 4513243 \\
\hline 52 & E side of 7th $\mathrm{N}$ of 56th & - & 40.76513 & 73.98019 & 586072 & 4513185 \\
\hline 53 & W of AvAmerica on S side 56th & - & 40.76403 & 73.97879 & 586192 & 4513064 \\
\hline 54 & E of AvAmerica on $\mathrm{N}$ side 56th & - & 40.76280 & 73.97553 & 586468 & 4512931 \\
\hline 55 & E of 5 th on $N$ side 56 th & - & 40.76223 & 73.97417 & 586584 & 4512869 \\
\hline 56 & N side 56th btwn Madison \& Park & $\mathrm{X}$ & 40.76142 & 73.97226 & 586746 & 4512781 \\
\hline 57 & N side 59th btwn Madison \& Park & $\mathrm{X}$ & 40.76344 & 73.97095 & 586854 & 4513007 \\
\hline 58 & $\mathrm{~W}$ of 5 th on $\mathrm{N}$ side 59 th & $\mathrm{X}$ & 40.76486 & 73.97403 & 586592 & 4513161 \\
\hline 59 & E of AvAmerica on $\mathrm{N}$ side 59th & $\mathrm{X}$ & 40.76549 & 73.97552 & 586466 & 4513229 \\
\hline 60 & $\mathrm{~N}$ side 59th btwn 7th \& 6th & $\mathrm{X}$ & 40.76640 & 73.97768 & 586282 & 4513328 \\
\hline 61 & $\mathrm{~N}$ side of 59th $\mathrm{W}$ of $7^{\text {th }}$ (NOT USED) & $\mathrm{X}$ & 40.76716 & 73.97948 & 586129 & 4513411 \\
\hline 62 & $\mathrm{~N}$ side of 59th E of 8th / Columbus Circle & $\mathrm{X}$ & 40.76777 & 73.98091 & 586008 & 4513477 \\
\hline 63 & S side of 58th btwn 8th \& 9th & $\mathrm{X}$ & 40.76782 & 73.98354 & 585786 & 4513480 \\
\hline 64 & S side of 59th $\mathrm{W}$ of 9th & $\mathrm{X}$ & 40.76935 & 73.98521 & 585643 & 4513648 \\
\hline
\end{tabular}


Table B.3. Rooftop Integrating Tracer Sampler Coordinates. The coordinates are for four

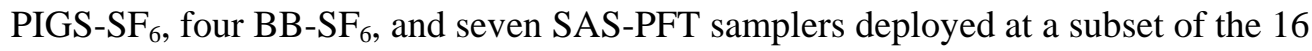
locations during each of the six IOPs (see Section 3.4.1).

\begin{tabular}{|c|l|c|c|c|c|c||}
\hline Loc \# & \multicolumn{1}{|c|}{ Location Description } & $\begin{array}{c}\text { Ht } \\
\text { (m AGL) }\end{array}$ & $\begin{array}{c}\text { Lat } \\
(\mathbf{d e g})\end{array}$ & $\begin{array}{c}\text { Long } \\
(\mathbf{d e g})\end{array}$ & $\begin{array}{c}\text { Easting } \\
(\mathbf{m})\end{array}$ & $\begin{array}{c}\text { Northing } \\
(\mathbf{m})\end{array}$ \\
\hline R01 & 1211 Ave of Am & 175 & 40.75862 & 73.98192 & 585934 & 4512461 \\
\hline R02 & 1221 Ave of Am - McGraw Hill & 194 & 40.75950 & 73.98214 & 585915 & 4512558 \\
\hline R03 & $\begin{array}{l}\text { 1221 Ave of Am - McGraw Hill } \\
\text { (setback) }\end{array}$ & 28 & 40.75988 & 73.98264 & 585872 & 4512600 \\
\hline R05 & 1271 Ave of Am - TimeLife NE & 183 & 40.76045 & 73.98071 & 586034 & 4512665 \\
\hline R06 & 1271 Ave of Am - TimeLife SE & 183 & 40.76032 & 73.98080 & 586027 & 4512650 \\
\hline R07 & $\begin{array}{l}\text { 1271 Ave of Am - TimeLife } \\
\text { (setback) }\end{array}$ & 27 & 40.76069 & 73.98179 & 585943 & 4512691 \\
\hline R08 & 1270 Ave of Am (upper setback) & 127 & 40.76007 & 73.97994 & 586100 & 4512623 \\
\hline R09 & Lehman Brothers SW corner & 168 & 40.76047 & 73.98316 & 585827 & 4512665 \\
\hline R10 & Lehman Brothers SE corner & 168 & 40.76034 & 73.98277 & 585860 & 4512651 \\
\hline R11 & Lehman Brothers (setback) & 41 & 40.76024 & 73.98286 & 585853 & 4512640 \\
\hline R12 & 1177 Ave of Am & 198 & 40.75727 & 73.98277 & 585864 & 4512310 \\
\hline R13 & 1345 Ave of Am & 197 & 40.76310 & 73.97933 & 586147 & 4512960 \\
\hline R14 & $\begin{array}{l}\text { 1501 Broadway - Paramount Clock } \\
\text { Tower North }\end{array}$ & 113 & 40.75719 & 73.98647 & 585552 & 4512298 \\
\hline R15 & $\begin{array}{l}\text { 1501 Broadway - Paramount Clock } \\
\text { Tower South }\end{array}$ & 113 & 40.75710 & 73.98656 & 585545 & 4512287 \\
\hline R16 & Lehman Brothers NE corner & 168 & 40.76055 & 73.98259 & 585875 & 4512674 \\
\hline R17 & Lehman Brothers NW corner & 168 & 40.76071 & 73.98299 & 585841 & 4512692 \\
\hline
\end{tabular}

Table B.4. Coordinates of 8 BATS-PFT Integrating Tracer Samplers Located at Various Subway Stations in Midtown

\begin{tabular}{|c|l|c|c|c|c||}
\hline Sampler \# & \multicolumn{1}{|c|}{ Location Description } & $\begin{array}{c}\text { Latitude } \\
(\mathbf{d e g})\end{array}$ & $\begin{array}{c}\text { Longitude } \\
(\mathbf{d e g})\end{array}$ & $\begin{array}{c}\text { Easting } \\
(\mathbf{m})\end{array}$ & $\begin{array}{c}\text { Northing } \\
(\mathbf{m})\end{array}$ \\
\hline S1 & Broadway and $72^{\text {nd }}$ St & 40.77827 & 73.98194 & 585907 & 4514642 \\
\hline S2 & $59^{\text {th }}$ St at Columbus Circle & 40.76796 & 73.98168 & 585943 & 4513498 \\
\hline S3 & $42^{\text {nd }}$ St and $7^{\text {th }}$ Ave & 40.75503 & 73.98775 & 585447 & 4512056 \\
\hline S4 & $34^{\text {th }}$ St and $7^{\text {th }}$ Ave & 40.75014 & 73.99120 & 585162 & 4511510 \\
\hline S5 & $2^{\text {rd }}$ St and $7^{\text {th }}$ Ave & 40.74421 & 73.99571 & 584789 & 4510848 \\
\hline S6 & $42^{\text {nd }}$ St and Broadway Ave & 40.75469 & 73.98682 & 585526 & 4512020 \\
\hline S7 & $42^{\text {nd }}$ St and Park Ave & 40.75180 & 73.97707 & 586353 & 4511708 \\
\hline S8 & $42^{\text {nd }}$ St and $5^{\text {th }}$ Ave & 40.75382 & 73.98196 & 585937 & 4511928 \\
\hline
\end{tabular}


Table B.5. Coordinates for BlueBox Integrating Samplers $\left(\mathrm{BB}-\mathrm{SF}_{6}\right)$ and Miran Analyzers. Location numbers with a prefix of "G" or "P" represent BlueBox locations, while the "M" denotes Miran locations.

\begin{tabular}{|c|c|c|c|c|c|}
\hline Location \# & Location Description & $\begin{array}{c}\text { Latitude } \\
\text { (deg) }\end{array}$ & $\begin{array}{c}\text { Longitude } \\
\text { (deg) }\end{array}$ & $\begin{array}{c}\text { Easting } \\
(\mathbf{m})\end{array}$ & $\begin{array}{c}\text { Northing } \\
\text { (m) }\end{array}$ \\
\hline G1 & S corner of $7^{\text {th }} \& 50^{\text {th }}$ & 40.76095 & 73.98313 & 585829 & 4512718 \\
\hline G2 & S side of $50^{\text {th }}$ btwn $6^{\text {th }} \& 7^{\text {th }}$ & 40.76060 & 73.98238 & 585893 & 4512680 \\
\hline G3 & $50^{\text {th }}$ Btwn $6^{\text {th }} \& 7^{\text {th }}$ & 40.76062 & 73.98195 & 585929 & 4512683 \\
\hline G4 & $50^{\text {th }}$ btwn $6^{\text {th }} \& 7^{\text {th }}$ & 40.76035 & 73.98132 & 585983 & 4512653 \\
\hline G5 & $\mathrm{N}$ corner $50^{\text {th }} \& 6^{\text {th }}$ & 40.76003 & 73.98060 & 586044 & 4512619 \\
\hline G6 & S corner of $6^{\text {th }} \& 50^{\text {th }}$ & 40.75979 & 73.98038 & 586063 & 4512592 \\
\hline G7 & S side of $49^{\text {th }}$ btwn $6^{\text {th }} \& 7^{\text {th }} \mathrm{W}$ of G10 & 40.75981 & 73.98231 & 585900 & 4512592 \\
\hline G8 & $\mathrm{N}$ side of $49^{\text {th }} \mathrm{E}$ of $7^{\text {th }}$ & 40.76040 & 73.98340 & 585807 & 4512657 \\
\hline G9/M4 & $\begin{array}{l}\text { Btwn } 49^{\text {th }} \& 50^{\text {th }} \text { btwn } 6^{\text {th }} \& 7^{\text {th }} E \text { of } \\
\text { Lehman Bros }\end{array}$ & 40.76026 & 73.98256 & 585878 & 4512642 \\
\hline G10 & S side of $49^{\text {th }}$ btwn $6^{\text {th }} \& 7^{\text {th }}$ E of G7 & 40.75973 & 73.98222 & 585908 & 4512584 \\
\hline G11/M1 & S side of $49^{\text {th }}$ btwn $6^{\text {th }} \& 7^{\text {th }}$ E of G10 & 40.75946 & 73.98150 & 585969 & 4512554 \\
\hline G12 & S corner of $6^{\text {th }} \& 49^{\text {th }}$ & 40.75913 & 73.98084 & 586025 & 4512518 \\
\hline G13 & $\begin{array}{l}\mathrm{N} \text { side } 48^{\text {th }} \text { btwn } 6^{\text {th }} \& 7^{\text {th }} \mathrm{W} \text { of } 1221 \\
\text { Ave of Am. }\end{array}$ & 40.75956 & 73.98306 & 585837 & 4512564 \\
\hline G14 & $\begin{array}{l}\text { N side } 48^{\text {th }} \text { btwn } 6^{\text {th }} \& 7^{\text {th }} S \text { of } 1221 \text { Ave } \\
\text { of Am. }\end{array}$ & 40.75934 & 73.98285 & 585855 & 4512540 \\
\hline G15 & $\begin{array}{l}\text { N side } 48^{\text {th }} \text { btwn } 6^{\text {th }} \& 7^{\text {th }} S \text { of } 1221 \text { Ave } \\
\text { of Am. }\end{array}$ & 40.75902 & 73.98202 & 585925 & 4512505 \\
\hline G16 & E corner $6^{\text {th }} \& 48^{\text {th }}$ & 40.75868 & 73.98117 & 585998 & 4512468 \\
\hline G17 & E side of $6^{\text {th }}$ btwn $48^{\text {th }} \& 49^{\text {th }}$ & 40.75897 & 73.98092 & 586018 & 4512500 \\
\hline G18 & S side of $49^{\text {th }}$ btwn $6^{\text {th }} \& 7^{\text {th }} \mathrm{W}$ of M2 & 40.76000 & 73.98279 & 585859 & 4512613 \\
\hline G19 & E corner $7^{\text {th }} \& 48^{\text {th }}$ & 40.75984 & 73.98401 & 585756 & 4512594 \\
\hline G20 & $\mathrm{N}$ side $48^{\text {th }} \mathrm{E}$ of $7^{\text {th }}$ & 40.75964 & 73.98356 & 585795 & 4512572 \\
\hline P1/M3 & $\mathrm{N}$ side $49^{\text {th }} \mathrm{W}$ of $6^{\text {th }}$ & 40.76011 & 73.98266 & 585870 & 4512625 \\
\hline M2 & S side $49^{\text {th }}$ btwn $6^{\text {th }} \& 7^{\text {th }} E$ of G18 & 40.75997 & 73.98276 & 585862 & 4512610 \\
\hline
\end{tabular}


Table B.6. Coordinates of Fixed FRD Fast-Response $\mathrm{SF}_{6}$ Analyzers by IOP and Release Number

\begin{tabular}{|c|c|c|c|c|c|c|}
\hline $\begin{array}{c}\text { Van } \\
\#\end{array}$ & $\begin{array}{c}\text { IOP } \\
\# \\
\end{array}$ & Location Description & $\begin{array}{c}\text { Latitude } \\
\text { (deg) }\end{array}$ & $\begin{array}{c}\text { Longitude } \\
\text { (deg) }\end{array}$ & $\begin{array}{c}\text { Easting } \\
(\mathrm{m})\end{array}$ & $\begin{array}{c}\text { Northing } \\
\text { (m) }\end{array}$ \\
\hline 1 & 1 & E of 7 th $S$ side of $49^{\text {th }}$ & 40.76004 & 73.98279 & 585859 & 4512617 \\
\hline 1 & 2 & E of 7 th $S$ side of $49^{\text {th }}$ & 40.76004 & 73.98279 & 585859 & 4512617 \\
\hline 1 & 3 & E of 7th S side of 49th $\sim 3 \mathrm{ft}$ east of IOP $1 / 2$ & 40.76004 & 73.98278 & 585860 & 4512617 \\
\hline 1 & 4 & On 47th W of Ave of Americas & 40.75863 & 73.98313 & 585832 & 4512461 \\
\hline 1 & 5 & E of Broadway N side of 50th & 40.76137 & 73.98386 & 585767 & 4512764 \\
\hline 1 & 6 & Btwn 5th \& 6th N side of 44th & 40.75552 & 73.98163 & 585963 & 4512117 \\
\hline 2 & 1 & E of 7th $N$ side of 50th & 40.76104 & 73.98306 & 585835 & 4512728 \\
\hline 2 & 2 & E of 7th $N$ side of 50th & 40.76104 & 73.98306 & 585835 & 4512728 \\
\hline 2 & 3 & E of 7th N side of 50th & 40.76104 & 73.98306 & 585835 & 4512728 \\
\hline 2 & 4 & Btwn 6th \& 7th on 47th & 40.75890 & 73.98379 & 585776 & 4512490 \\
\hline 2 & 5 & E of 7 th $N$ side of 51 st & 40.76166 & 73.98257 & 585876 & 4512797 \\
\hline 2 & 6 & $\mathrm{~W}$ of 6 th $\mathrm{N}$ side of 44 th & 40.75625 & 73.98335 & 585817 & 4512196 \\
\hline 4 & 1 & Btwn 6th \& 7th on S side 54th (1s & 280 & 73 & 586116 & 4512927 \\
\hline 4 & 1 & $\begin{array}{l}\text { Btwn 6th \& 7th on S side 54th - pulled van } \\
\text { forward a bit (2nd Release) }\end{array}$ & 40.76279 & 73.97968 & 586118 & 4512926 \\
\hline 4 & 2 & E of 6th N side of 52nd (1st release) & 40.76110 & 73.97929 & 586153 & 4512738 \\
\hline 4 & 2 & $\begin{array}{l}\text { Btwn 8th \& Broadway S side of 52nd (2nd } \\
\text { release) }\end{array}$ & 40.76294 & 73.98387 & 585764 & 4512938 \\
\hline 4 & 3 & Btwn 6th \& 7th on S side of 52nd & 40.76195 & 73.98153 & 585963 & 4512831 \\
\hline 4 & 4 & Btwn 6th \& 7th on N side of 44th & 40.75664 & 73.98429 & 585737 & 4512239 \\
\hline 4 & 5 & W of Broadway on S side of 53rd & 40.76341 & 73.98301 & 585836 & 4512991 \\
\hline 4 & 6 & Btwn 6th \& 7th on S side of 46th & 40.75774 & 73.98318 & 585829 & 4512362 \\
\hline 7 & 1 & E of 7th on $N$ side of 47 th & 40.75916 & 73.98443 & 585722 & 4512518 \\
\hline 7 & 2 & E of 8th on $N$ side of 45th (1st release) & 40.75906 & 73.98810 & 585412 & 4512504 \\
\hline 7 & 2 & E of 6th on S side of 48th (2nd release) & 40.75851 & 73.98113 & 586001 & 4512449 \\
\hline 7 & 3 & E of 7th on N side of 47th & 40.75916 & 73.98443 & 585722 & 4512518 \\
\hline 7 & 4 & Btwn 7th \& 8th on 44th & 40.75750 & 73.98648 & 585551 & 4512332 \\
\hline 7 & 5 & E of 8th on $N$ side 51 st & 40.76287 & 73.98545 & 585631 & 4512929 \\
\hline 7 & 6 & $50 \mathrm{~m}$ from 6 th on $\mathrm{N}$ side of $47 \mathrm{th}$ & 40.75706 & 73.98158 & 585965 & 4512288 \\
\hline
\end{tabular}


Appendix C

Coordinates of MID05 Meteorological Instruments 


\section{Appendix C: Coordinates of MID05 Meteorological Instruments}

The following tables give the location description and coordinates of the meteorological instruments deployed during MID05. Latitude and longitude are in degrees north of the equator and west of the prime meridian, respectively. Easting and northing coordinates are in Universal Transverse Mercator (UTM) Zone 18 referenced to the 1983 North American Datum.

Table C.1. Meteorological Instrument Coordinates During MID05. Ground elevation is given in meters above mean sea level (m MSL) while building height (when appropriate) is given in $\mathrm{m}$ above ground level (m AGL), and the measurement height is $\mathrm{m}$ above the surface (ground or building).

\begin{tabular}{|c|c|c|c|c|c|c|c|c|}
\hline $\begin{array}{l}\text { Station } \\
\text { Name }\end{array}$ & Location Description & $\begin{array}{l}\text { Ground } \\
\text { Elev } \\
(\mathrm{m} \mathrm{msl})\end{array}$ & $\begin{array}{l}\text { Bldg } \\
\text { Ht } \\
\text { (m) }\end{array}$ & $\begin{array}{c}\text { Meas. } \\
\text { Ht } \\
\text { (m) }\end{array}$ & $\begin{array}{l}\text { Lat } \\
(\text { deg) }\end{array}$ & $\begin{array}{l}\text { Long } \\
\text { (deg) }\end{array}$ & $\begin{array}{c}\text { East } \\
(\mathrm{m})\end{array}$ & $\begin{array}{l}\text { North } \\
\text { (m) }\end{array}$ \\
\hline \multicolumn{9}{|c|}{ NWS ASOS } \\
\hline $\mathrm{CPK}$ & Central Park & 30 & 15 & 1 & 40.77944 & 73.96907 & 586992 & 4514785 \\
\hline EWR & Newark Airport & 2 & - & 10 & 40.69250 & 74.16867 & 570240 & 4504955 \\
\hline FOK & Westhampton Gabreski Airport & 20 & - & 10 & 40.84999 & 72.63334 & 699499 & 4524801 \\
\hline HPN & White Plains Westchester Co Airport & 120 & - & 10 & 41.06667 & 73.70000 & 609223 & 4546972 \\
\hline HWV & Shirley Brookhaven Airport & 25 & - & 10 & 40.81667 & 72.86667 & 679919 & 4520596 \\
\hline ISP & Islip Long Island Macarthur Airport & 25 & - & 10 & 40.80000 & 73.10000 & 660279 & 4518292 \\
\hline JFK & JFK Airport & 3 & - & 10 & 40.63333 & 73.76667 & 604299 & 4498786 \\
\hline LGA & Laguardia Airport & 3 & - & 10 & 40.78006 & 73.87345 & 595060 & 4514953 \\
\hline \multicolumn{9}{|c|}{ Existing University and NOAA Stations } \\
\hline CCNY & City College of NY Roof & 36 & 51 & 8 & 40.81923 & 73.94911 & 588623 & 4519222 \\
\hline EML & Environmental Measurements Lab Roof & 5 & 62 & 6 & 40.72838 & 74.00666 & 583884 & 4509080 \\
\hline LBR1 & LehmanBrothers roof & 17 & 175 & 15 & 40.76049 & 73.98326 & 585819 & 4512667 \\
\hline SIT3 & $\begin{array}{l}\text { Stevens Institute of Technology (SIT) - } \\
\text { Howe Ctr }\end{array}$ & 25 & 70 & 10 & 40.74486 & 74.02384 & 582413 & 4510893 \\
\hline \multicolumn{9}{|c|}{ Meteorological and Profile Stations } \\
\hline SIT1 & SIT - radiosonde & 19 & - & (a) & 40.74459 & 74.02712 & 582136 & 4510860 \\
\hline SIT2 & SIT tennis court - radar wind profiler & 7 & - & (a) & 40.74731 & 74.02432 & 582369 & 4511165 \\
\hline GM1 & General Motors Bldg roof - met station & 15 & 219 & 3 & 40.76358 & 73.97237 & 586734 & 4513021 \\
\hline GM2 & General Motors Bldg roof - sodar & 15 & 215 & (a) & 40.76365 & 73.97225 & 586744 & 4513029 \\
\hline LBR2 & LehmanBrothers S setback - met station & 17 & 41 & 0 & 40.76038 & 73.98322 & 585822 & 4512655 \\
\hline METL1 & MetLife Bldg - met station & 18 & 246 & 6 & 40.75336 & 73.97650 & 586399 & 4511882 \\
\hline METL2 & MetLife Bldg - sodar & 18 & 246 & (a) & 40.75319 & 73.97638 & 586409 & 4511863 \\
\hline MGH1 & $\begin{array}{l}\text { McGrawHill Roof SE corner - met } \\
\text { station }\end{array}$ & 17 & 208 & 6 & 40.75911 & 73.98176 & 585947 & 4512515 \\
\hline MGH2 & $\begin{array}{l}\text { McGrawHill N setback NW end - met } \\
\text { station }\end{array}$ & 17 & 34 & 0 & 40.75990 & 73.98263 & 585873 & 4512602 \\
\hline OPP & $\begin{array}{l}\text { One Penn Plaza Roof SW corner - met } \\
\text { station }\end{array}$ & 11 & 224 & 6 & 40.75156 & 73.99285 & 585021 & 4511666 \\
\hline PPZ & Park Ave Plaza roof - met station & 17 & 177 & 6 & 40.75905 & 73.97359 & 586637 & 4512517 \\
\hline
\end{tabular}


Table C.1. Cont'd

\begin{tabular}{|c|c|c|c|c|c|c|c|c|}
\hline \multicolumn{9}{|c|}{ Street Level Sonics } \\
\hline S1 & $6^{\text {th }}$ btwn $49^{\text {th }} \& 50^{\text {th }}$. Rockefeller Ctr & 18 & - & 3 & 40.75941 & 73.98063 & 586042 & 4512550 \\
\hline S2 & $\mathrm{N}$ entrance to McGrawHill Bldg on $49^{\text {th }}$ & 17 & - & 3 & 40.75967 & 73.98207 & 585920 & 4512577 \\
\hline S3 & S side of McGrawHill Bldg on $48^{\text {th }}$ & 17 & - & 3 & 40.75906 & 73.98218 & 585912 & 4512509 \\
\hline S4 & $6^{\text {th }} S$ of S1 & 18 & - & 3 & 40.75879 & 73.98110 & 586003 & 4512480 \\
\hline S5 & $6^{\text {th }}$ btwn $49^{\text {th }} \& 50^{\text {th }}$. & 19 & - & 3 & 40.76021 & 73.98004 & 586091 & 4512639 \\
\hline S6 & $50^{\text {th }}$ btwn $6^{\text {th }} \&$ Broadway & 19 & - & 3 & 40.75956 & 73.97975 & 586116 & 4512567 \\
\hline S7 & $7^{\text {th }}$ btwn $48^{\text {th }} \& 49^{\text {th }}$ St & 16 & - & 3 & 40.76011 & 73.98386 & 585769 & 4512624 \\
\hline S8 & $7^{\text {th }}$ btwn $49^{\text {th }} \& 50^{\text {th }}$ & 17 & - & 3 & 40.76065 & 73.98347 & 585801 & 4512684 \\
\hline S9 & $50^{\text {th }}$ btwn $6^{\text {th }} \& 7^{\text {th }}$ & 17 & - & 3 & 40.76081 & 73.98272 & 585864 & 4512703 \\
\hline S10 & $49^{\text {th }}$ btwn 7 th $\& 6^{\text {th }}$ & 17 & - & 3 & 40.76028 & 73.98315 & 585828 & 4512644 \\
\hline S11 & S side of $45^{\text {th }}$ btwn $6^{\text {th }} \& 7^{\text {th }}$ & 18 & - & 3 & 40.75698 & 73.98335 & 585816 & 4512277 \\
\hline S12 & $\mathrm{N}$ side of $54^{\text {th }}$ btwn 6 th $\& 7^{\text {th }}$ & 20 & - & 3 & 40.76266 & 73.97908 & 586169 & 4512912 \\
\hline \multicolumn{9}{|c|}{$\begin{array}{l}\text { (a) Radiosondes measure meteorological quantities up to } \sim 10 \mathrm{~km} \text {; Sodars measure winds up to } \sim 200 \mathrm{~m} \text {; and radar wind profilers } \\
\text { measure winds up to } \sim 2500 \mathrm{~m} \text {. }\end{array}$} \\
\hline
\end{tabular}

Table C.2. HOBO Positions During MID05. HOBOs were mounted on light poles at about 3 m AGL.

\begin{tabular}{|c|l|c|c|c|c|}
\hline $\begin{array}{c}\text { Loc } \\
\text { \# }\end{array}$ & \multicolumn{1}{|c|}{ Location Description } & $\begin{array}{c}\text { Latitude } \\
(\mathbf{d e g})\end{array}$ & $\begin{array}{c}\text { Longitude } \\
(\mathbf{d e g})\end{array}$ & $\begin{array}{c}\text { Easting } \\
(\mathbf{m})\end{array}$ & $\begin{array}{c}\text { Northing } \\
(\mathbf{m})\end{array}$ \\
\hline 1 & SW corner of 28th \& 6 & 40.74615 & 73.99092 & 585191 & 4511068 \\
\hline 2 & E side of 6th btwn 30th \& 31st & 40.74745 & 73.98934 & 585322 & 4511213 \\
\hline 3 & NE corner of 38th \& 6 & 40.75234 & 73.98578 & 585617 & 4511760 \\
\hline 4 & W side of 6th btwn 43rd \& 44th $^{\text {th }}$ & 40.75578 & 73.98360 & 585796 & 4512144 \\
\hline 5 & E side of 6th btwn 47th \& 48th & 40.75839 & 73.98138 & 585980 & 4512436 \\
\hline 6 & NE corner of 54th \& 6 & 40.76241 & 73.97843 & 586224 & 4512885 \\
\hline 7 & E side of 6th btwn 58th \& 59th & 40.76517 & 73.97643 & 586389 & 4513193 \\
\hline 8 & N of the Dairy Visitors Center in Central Park & 40.76981 & 73.97333 & 586645 & 4513711 \\
\hline 9 & Abt 1 block W of 5th \& 69th in Central Park & 40.77143 & 73.96975 & 586945 & 4513895 \\
\hline 10 & NW corner of 48th \& 12 & 40.76577 & 73.99777 & 584587 & 4513239 \\
\hline 11 & S side 48th btwn 10th \& 11th & 40.76360 & 73.99325 & 584972 & 4513002 \\
\hline 12 & N side of 48th btwn 8th \& 9th & 40.76206 & 73.98929 & 585308 & 4512835 \\
\hline 13 & N side of 48th btwn Broadway \& 8th & 40.76036 & 73.98527 & 585649 & 4512651 \\
\hline 14 & S side of 48th btwn Madison \& 5th & 40.75689 & 73.97737 & 586321 & 4512273 \\
\hline 15 & S side of 48th btwn 3rd \& Lexington & 40.75479 & 73.97238 & 586745 & 4512045 \\
\hline 16 & S side of 48th btwn 1st \& 2nd & 40.75333 & 73.96886 & 587044 & 4511886 \\
\hline 17 & NW corner of FDR \& 48 & 40.75192 & 73.96505 & 587367 & 4511733 \\
\hline
\end{tabular}




\section{Distribution}

No. of

Copies

\section{OFFSITE}

1 Bruce Davis

Department of Homeland Security

Attn: S\&T/Bruce Davis/4-5893

Anacostia Naval Annex

245 Murray Lane, SW, Building 410

Washington, DC 20528

(202) 254-5893

[send FedEx/UPS]

1 Teresa Lustig

Department of Homeland Security

Attn: S\&T/Teresa Lustig/4-5766

Anacostia Naval Annex

245 Murray Lane, SW, Building 410

Washington, DC 20528

(202) 254-5766

[send FedEx/UPS]

ONSITE

10 Pacific Northwest National Laboratory

K.J. Allwine (7) K9-30

J.E. Flaherty (1) K9-30

Information Release (2) P8-55

Distr. 1 